\title{
Nigeria: Selected Issues and Statistical Appendix
}

This Selected Issues and Statistical Appendix paper for Nigeria was prepared by a staff team of the International Monetary Fund as background documentation for the periodic consultation with the member country. It is based on the information available at the time it was completed on June 24, 2005. The views expressed in this document are those of the staff team and do not necessarily reflect the views of the government of Nigeria or the Executive Board of the IMF.

The policy of publication of staff reports and other documents by the IMF allows for the deletion of market-sensitive information.

To assist the IMF in evaluating the publication policy, reader comments are invited and may be sent by e-mail to publicationpolicy@imf.org.

Copies of this report are available to the public from

International Monetary Fund $\bullet$ Publication Services

700 19th Street, N.W. • Washington, D.C. 20431

Telephone: (202) 6237430 • Telefax: (202) 6237201

E-mail: publications@imf.org • Internet: http://www.imf.org

Price: $\$ 15.00$ a copy

\section{International Monetary Fund Washington, D.C.}





\section{INTERNATIONAL MONETARY FUND}

\section{NIGERIA}

\section{Selected Issues and Statistical Appendix}

Prepared by a staff team consisting of Mr. Menachem Katz (Head), Mr. Ulrich Bartsch, Ms. Jeanne Gobat (all AFR), Mr. Lynge Nielsen (PDR), and Mr. Mauricio Villafuerte (FAD)

Approved by the African Department

June 24, 2005

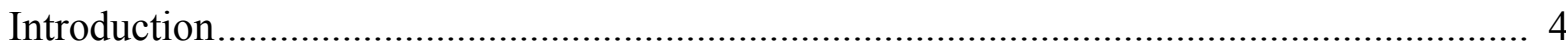

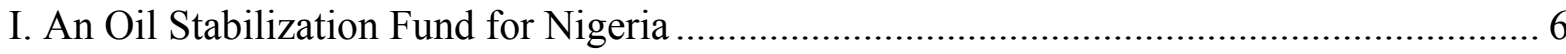

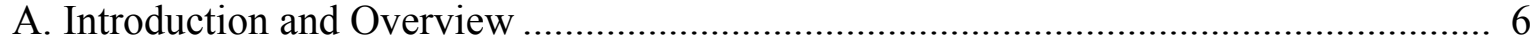

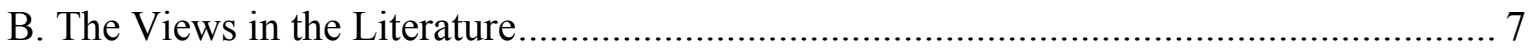

C. Stabilizing Fiscal Spending ............................................................................... 10

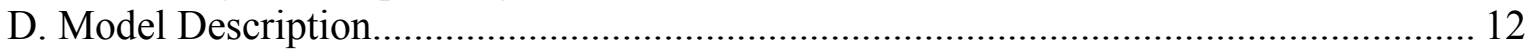

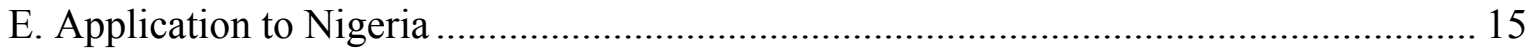

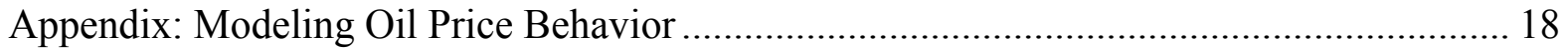

II. Reforms for Private Sector-Led growth ........................................................... 22

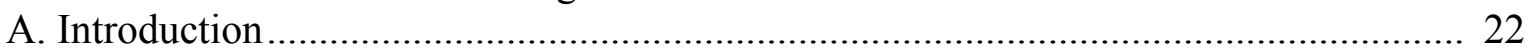

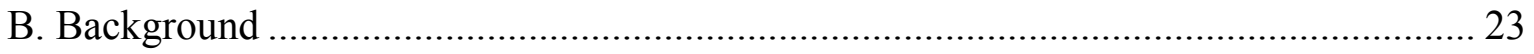

Public sector governance ........................................................................... 28

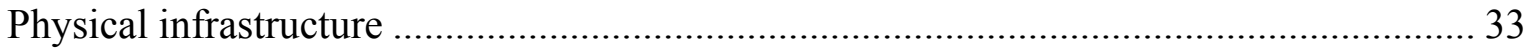

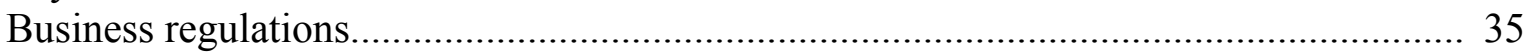

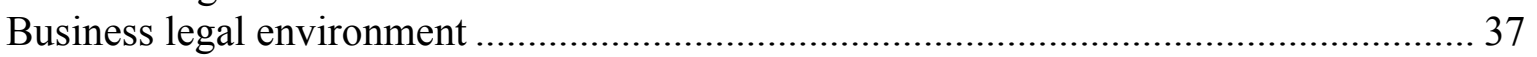

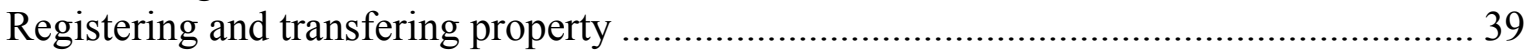

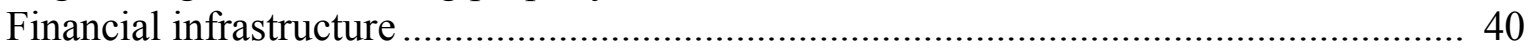

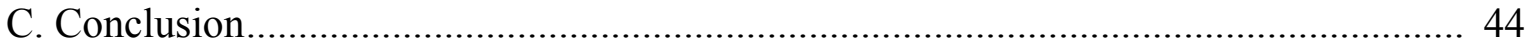

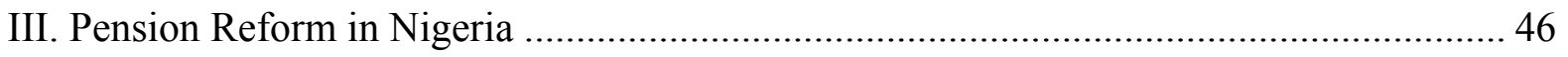

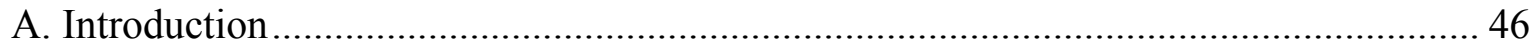

B. Pension Reform: Issues and Country Experiences................................................. 46

C. Nigeria's 2004 Pension Reform Act: Implications and Challenges............................ 49

Previous pension system and the need for reform .................................................. 49

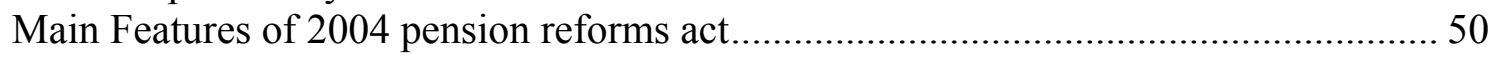

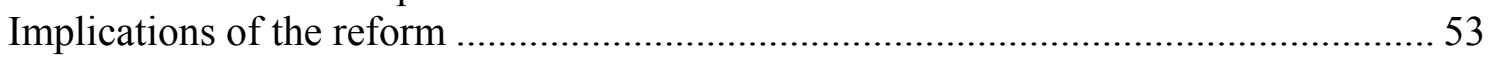

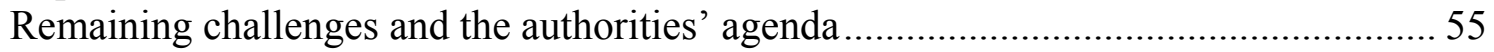

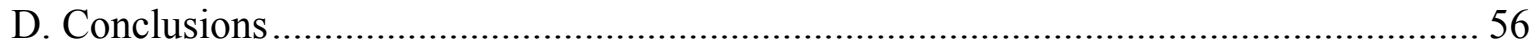




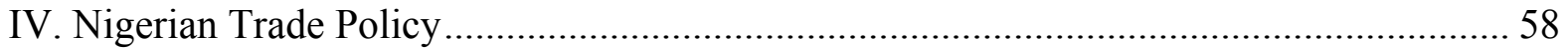

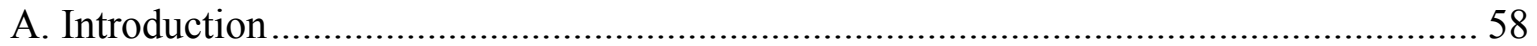

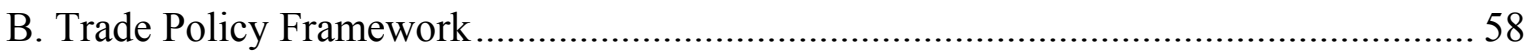

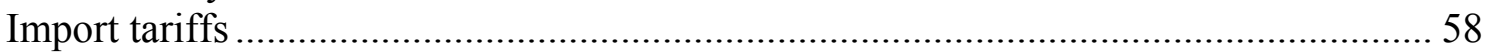

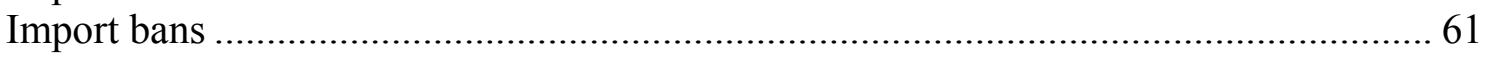

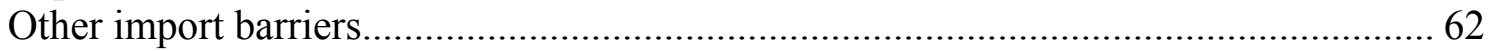

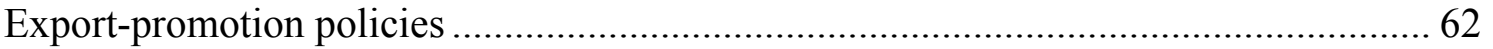

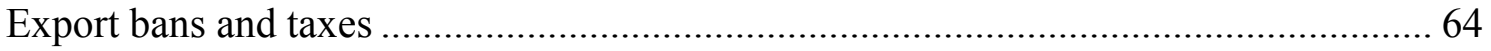

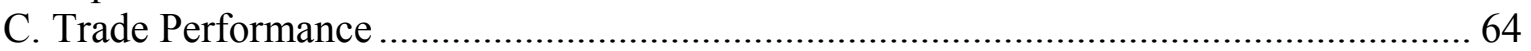

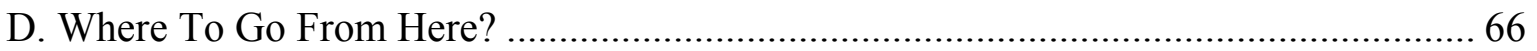

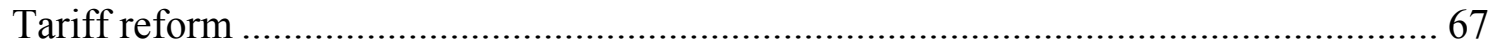

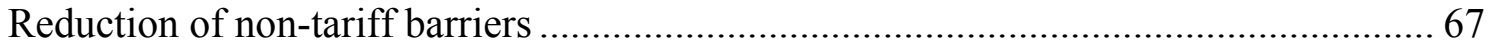

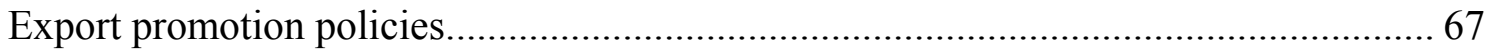

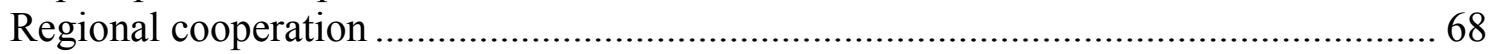

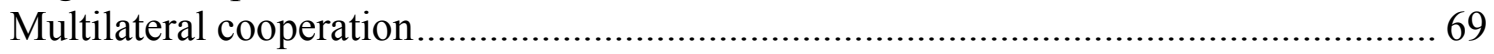

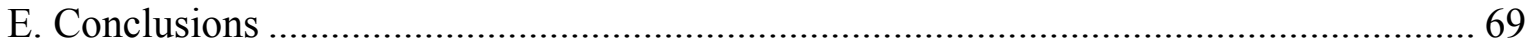

Text Tables

I-1. Root Mean Squared Errors for Price Projections Based on Moving Averages, 1861-2003 ………………….......................................................11

I-2. Changes in Projected Prices, 1861-2003 …….......................................................... 11

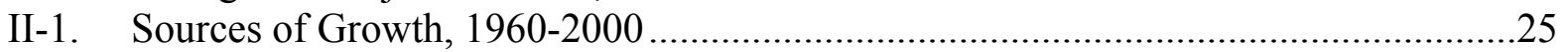

II-2. Competitiveness Indicators-Nigeria Compared to Other Sub-Saharan

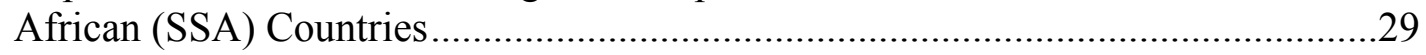

III-1. Some Major Pension Reforms (Defined-Contribution Systems).................................4

III-2. Federal Pension Liabilities, May 2002 ...................................................................5

III-3. Structure of Recently Reformed Pension Systems (Including Nigeria) .......................53

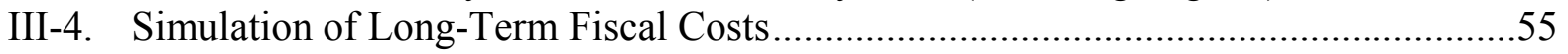

IV-1. Import Prohibitions as of November 2004...........................................................6

IV-2. Trade, Foreign Investment and Growth, 1994-2004.................................................65

IV-3. Average Tariffs in ECOWAS Countries, end-2004 .................................................68

\section{Text Figures}

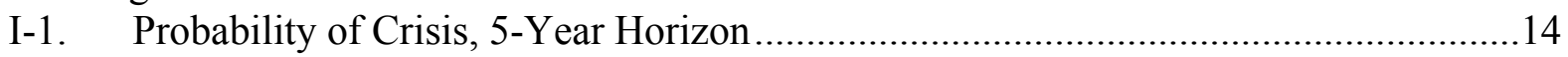

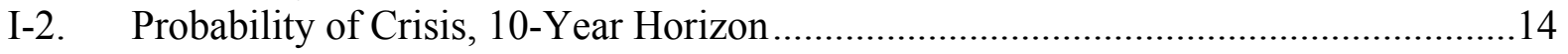

I-3. Probability of Crisis, 15-Year Horizon .................................................................... 14

I-4. Moving Averages of Recent Oil Prices, Nigeria's Budget Reference

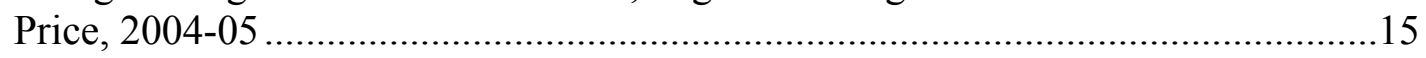

I-5. Probability of Forced Adjustment in Nigeria, 2005-10 .............................................16

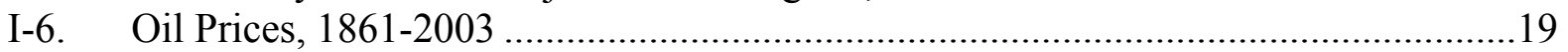

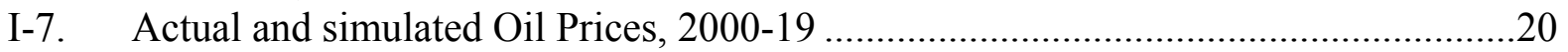

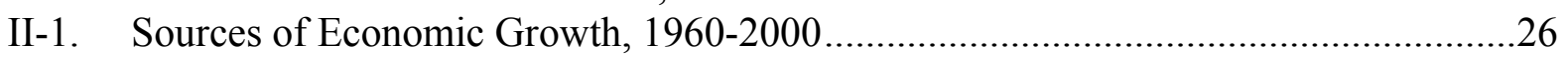

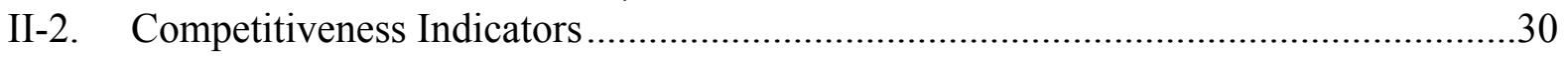

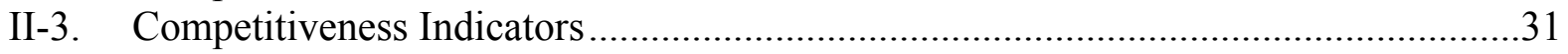

II-4. Financial Depth, Broad Money (in percent of GDP), 2000-04 ..................................4 


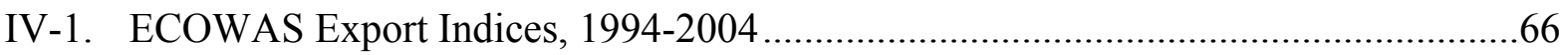

IV-2. ECOWAS Export to GDP Ratios, 1994-2004 ………...............................................66

\section{Text Boxes}

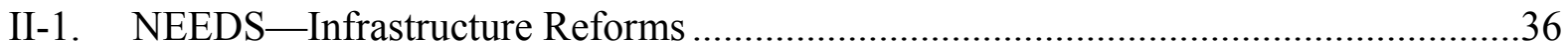

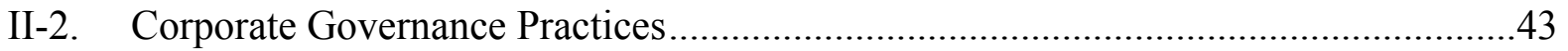

II-3. Authorities' Financial Sector Reform Strategy.........................................................44

Statistical Appendix Tables

1. Revised Gross Domestic Product by Sector of Origin at Current Prices,

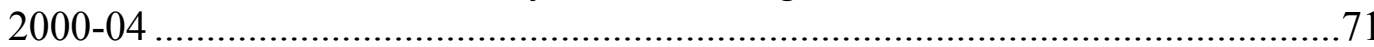

2. Revised Gross Domestic Product by Sector of Origin at Constant 1990 Prices,

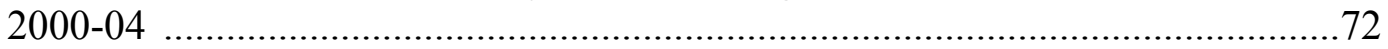

3. Revised Gross Domestic Product by Expenditure Category at Current Prices,

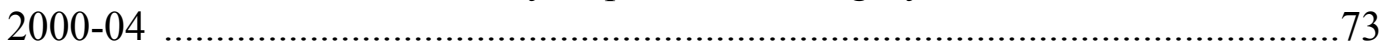

4. Revised Gross Domestic Product by Expenditure at Constant 1990 Prices,

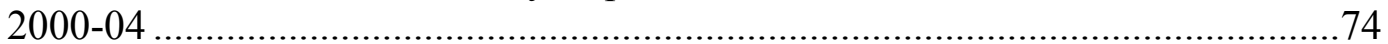

5. Selected Petroleum Statistics, 2000-04 ...............................................................

6. Selected Indicators of Agricultural Production and Prices, 2000-03 ..........................76

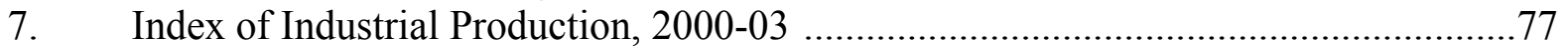

8. National Consumer Price Indices, 2000-04 ........................................................

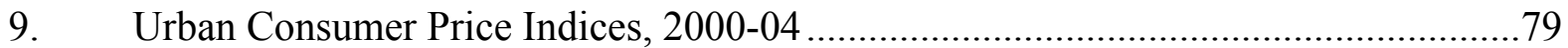

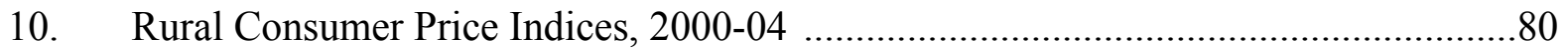

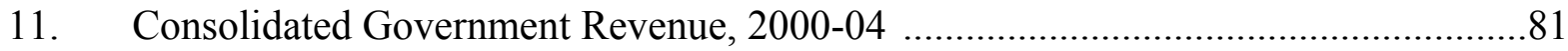

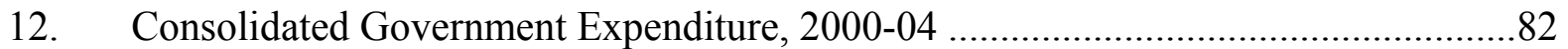

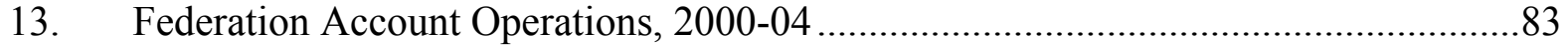

14. Summary Federal Government Fiscal Operations, 2000-04 …………....................8

15. Total Expenditure of the Federal Government by Functional Classification,

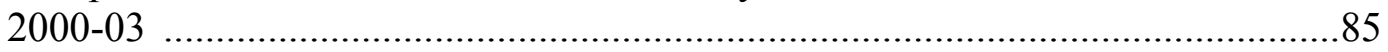

16. Recurrent Expenditure of the Federal Government by Functional Classification,

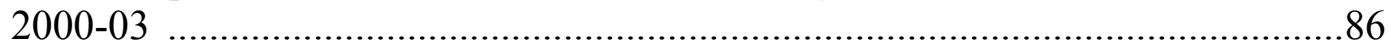

17. Capital Expenditure of the Federal Government by Functional Classification,

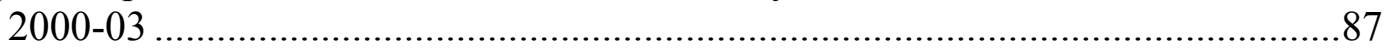

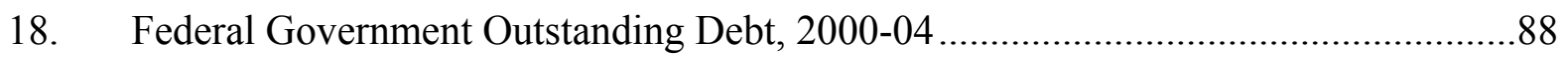

19. Summary of Budgetary Operations of State and Local Governments and special

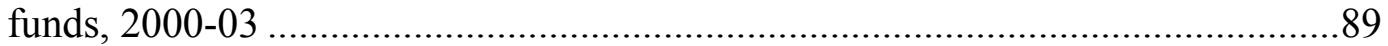

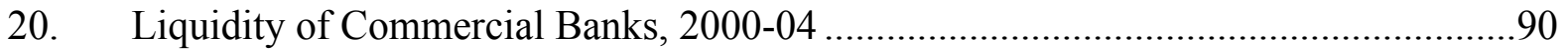

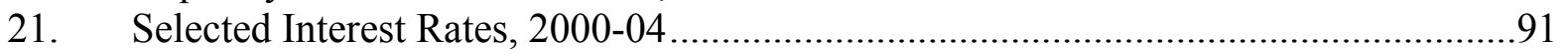

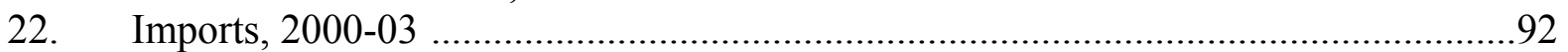

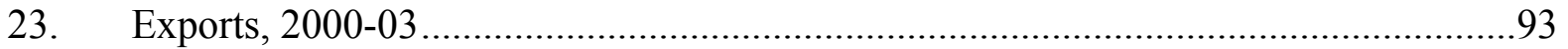

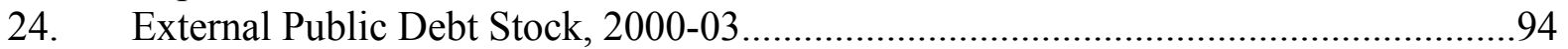

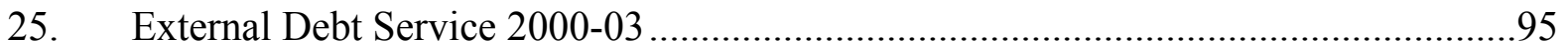

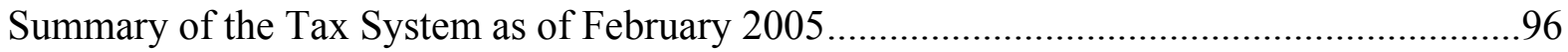




\section{INTRODUCTION}

1. This selected issues paper and the statistical appendix provide background information to the staff report on the 2005 Article IV consultation with Nigeria. ${ }^{1}$

2. The staff report discusses the challenges facing Nigeria in building on the achievements of 2004. The authorities will have to maintain macroeconomic stability while implementing ambitious structural reforms aimed at reducing the costs of doing business in Nigeria and supporting faster growth and poverty reduction. The staff report evaluates positively the decisive actions Nigeria has already taken in key areas and draws attention to the challenges ahead, such as the implementation of a more expansionary 2005 federal budget in the context of high oil prices, the strengthening of public expenditure management, improvements in infrastructure and public service delivery, privatization, and tariff reform. This paper supports the staff report's evaluation of these key challenges.

\section{An Oil Stabilization Fund for Nigeria}

3. The first chapter analyzes the potential for using an oil stabilization fund to protect public spending from oil price volatility. It also presents the rationale for using a mediumterm moving average of past oil prices to determine fiscal policy, depositing surpluses in a fund, and tapping into the fund to finance deficits. Based on the statistical properties of past oil prices (highly volatile with a very weak tendency to return to their mean after a shock), the chapter argues that fiscal policy cannot be based on a long-term average oil price, because surpluses accumulated during periods of high oil prices would probably be very large, and deficits during periods of low oil prices would probably deplete any existing fund. In both cases, the government would be forced to abandon its predetermined fiscal policy, which could entail sizable adjustment costs. While using a moving average would not completely delink fiscal spending from oil price volatility, it would prevent sudden, large adjustments.

4. The analysis shows that with fiscal policy determined by a moving average of oil prices over the past 3-5 years, the government needs liquidity reserves of US\$16-18 billion to be reasonably well insured against a necessary adjustment.

\section{Reforms for Private Sector-Led Growth}

5. The government's ambitious and broad-based medium-term economic reform strategy - the National Economic Empowerment and Development Strategy (NEEDS) - aims to break with the misguided government-led development paradigm of the past that created a difficult environment for the private sector. The second chapter describes the deep-rooted structural and economic problems facing the economy, and argues that they need to be

\footnotetext{
${ }^{1}$ See Nigeria: Staff Report for the 2005 Article IV Consultation, IMF Country Report, www.imf.org.
} 
addressed to help Nigeria grow out of a low-savings-and-investment trap. It draws heavily on the NEEDS, and two World Bank surveys, Doing Business and Investment Climate Survey; and the World Economic Forum's Global Competitiveness Report.

6. The chapter discusses the main areas of priority in the NEEDS: public sector governance, infrastructure, business regulations and the legal environment, and the financial sector. It concludes that the emphasis on these areas in the NEEDS shows that the authorities have identified those reforms that will improve the investment climate and correct for past policy mistakes. The chapter argues that, with the right policies, Nigeria can achieve higher per capita growth, and make significant progress in lowering poverty. The main challenge facing Nigeria's policymakers is to persevere and implement the reform agenda consistently.

\section{Pension Reform}

7. With its approval of the new Pension Act in June 2004, Nigeria introduced a major reform of the pension system. This act seeks to establish a contributory, fully funded scheme for both the public and private sectors. It will be based on individual accounts that will be privately managed by administrators, with pension fund assets held by custodians. It replaces a range of largely unregulated and highly diverse pension arrangements, including the payas-you-go pension systems for federal government employees. Chapter III describes the reform and analyzes its potential benefits and drawbacks on the basis of the literature on oldage security and international experience with similar reforms.

8. The chapter points out that the pension reform, as currently designed, entails substantial short-term fiscal costs, with apparently limited savings in long-term fiscal costs, and implies a sizable reduction in benefits for future pensioners relative to current beneficiaries. In that context, the chapter argues for a reduction in both statutory benefits for current pensioners and documented liabilities to workers shifting from the old to the new system, as well as for protection for the lowest-income beneficiaries through progressive cuts in statutory benefits. The reform's potential benefits in terms of improved management of pension funds and financial deepening will depend critically on the establishment of adequate technological, institutional, and regulatory frameworks.

\section{Nigerian Trade Policy}

9. The fourth chapter provides an overview of trade policies in Nigeria, with a particular focus on changes in these policies in the past two years. It shows that little progress has been made toward liberalizing trade and that Nigeria's trade policy regime continues to be among the most restrictive in the world. Nigeria's homegrown strategy, or NEEDS, adopted in 2004 recognizes the shortcomings of the current trade policy framework. Consistent with the trade policy strategy elaborated in NEEDS, the government will significantly lower import barriers. The chapter concludes with suggestions on how the trade reforms can be broadened and deepened. 


\section{An Oil Stabilization Fund FOr Nigeria ${ }^{2}$}

\section{A. Introduction and Overview}

10. In oil-dependent countries, a major issue is how to stabilize fiscal spending when government revenue fluctuates along with the international price of oil. Nigeria is highly dependent on revenue from oil exports, in terms of both its balance of payments and government revenue. Most of Nigeria's oil and gas resources, which are abundant relative to current production levels, are exploited by joint ventures between foreign oil companies and the Nigerian National Petroleum Corporation (NNPC). Domestic income from oil and gas accrues to a very large extent to the government in the form of proceeds from equity oil sales and taxes on private companies. Private income from oil and gas leaves Nigeria largely through profit remittances. Because international oil prices are volatile, the government's revenue from oil and gas is also volatile. Fiscal spending has been equally volatile, leading to boom-bust cycles, which are partly to blame for Nigeria's disappointing growth performance since independence. ${ }^{3}$

11. To stabilize fiscal spending, the government must first stabilize the non-oil deficit — that is, the difference between its non-oil revenue and its spending, thereby resulting in an overall surplus or deficit when oil prices are higher or lower than anticipated. Overall deficits incurred in years with low oil prices need to be financed, and surpluses in years with high oil prices need to be disposed of. Because Nigeria cannot easily borrow in international capital markets, it may not have a source of financing for budget deficits when oil prices are low. A stabilization fund would allow the government to pull through an oil price trough and absorb windfall revenue when prices are high. This paper discusses fiscal policy and the design of a stabilization fund.

\section{The government has two alternatives for holding financial assets in a} stabilization fund that provides fiscal liquidity reserves. The assets can either be part of government deposits in the central bank, or be held in a separate foreign currency commercial bank account. ${ }^{4}$ In 2004, Nigeria deposited its windfall oil revenue in a central bank account, with monetary and exchange rate policy determining the relationship between fiscal deposits in the central bank and foreign reserves held by the central bank. Obviously, government deposits would closely mirror foreign reserves taking into account the import content of government spending to avoid liquidity injection or withdrawal in line with government deposit drawdown or buildup.

\footnotetext{
${ }^{2}$ Prepared by Ulrich Bartsch.

${ }^{3}$ Engel and Meller (1993), Caballero (2000), IMF (2004), Krichene (forthcoming).

${ }^{4}$ For macroeconomic stabilization purposes, it is important that the financial assets be kept in foreign currency to limit the domestic liquidity injection from oil exports.
} 
13. This chapter focuses on two key issues. First, given uncertainty of future oil prices, how much of its revenues should the Nigerian government spend? Fiscal policy design would be relatively straightforward if oil prices fluctuated in a reasonably short time around a longterm average, in which case the government should spend its mean expected oil revenue while maintaining a precautionary liquidity reserve for low-price periods. But because oil prices show very weak mean reversion - that is, oil price shocks are of long duration and the long-term average oil price is of little use for policymaking as shown in the appendix - the government has more difficulty determining its fiscal policy.

14. The chapter proposes that Nigeria use moving averages of past oil prices to estimate its future revenue and that it base its spending on this expected revenue. This solution strikes a balance between using this year's price to estimate next year's revenue, which would lead to the smallest forecast error because of the statistical properties of oil prices - such a policy would transmit oil price volatility to the economy - and using a longterm average price, which could lead to large and persistent surpluses and deficits because of the slow mean reversion of oil prices. Given the trade-off between stability of spending and over- or under-shooting actual oil revenue, this chapter argues that Nigeria should base spending on revenue projected on the basis of moving averages of oil prices over three to five years.

15. Irrespective of which method the government uses to guide its spending, any fiscal policy would run up against the difference between budgeted oil revenue and realized oil revenue. The question that arises about the design of a stabilization fund is, therefore, how much is enough: what level of assets should the government have in a stabilization fund to give assurance that it can maintain a stable fiscal policy.

16. This chapter uses repeated simulations of a numerical fiscal policy model with randomly generated parameters (Monte Carlo simulations) to look at the probability that a given level of assets in the stabilization fund is exhausted over a certain number of years. The model presented in Section D is based on randomly generated oil prices, where the data-generation process was estimated on the basis of real oil prices over the period 18612004 (see appendix). The simulations provide probabilities of the government's encountering

a budget crisis when, because of a liquidity constraint, it cannot spend the amounts budgeted. The simulations show that with a fiscal policy based on moving averages over three to five years, a stabilization fund of about 75 percent of 2004 oil revenue would be adequate. Section E derives the implications of the Monte Carlo simulations for fiscal policy in Nigeria and concludes that fiscal liquidity reserves of US\$16-18 billion would be adequate.

\section{B. The Views in the Literature}

17. The literature on oil-dependent countries and revenue volatility clearly points out that delinking spending from revenue is important to promote macroeconomic 
stability and create an enabling environment for growth. ${ }^{5}$ Two possibilities for delinking are discussed: self-insurance through diversification of revenue and stabilization funds and transfer of risk to international capital markets (hedging). ${ }^{6}$ Diversification may take a long time and may not be compatible with a country's comparative advantage. Hedging may be constrained by the limitations of futures markets: liquidity in long-dated instruments with maturities of more than one year is still limited (compared with Nigeria's production volumes). In addition, hedging requires a high level of skill and oversight, and its political pay-offs may be very asymmetrical: the minister of finance may gain little political capital from the stabilization of revenue when oil prices fall, but may face severe criticism when prices rise and the country does not benefit from the upswing. Doubts over Nigeria's creditworthiness may also make it difficult for the government to participate effectively in futures markets and would prevent it from borrowing when oil prices fell. ${ }^{7}$

\section{Countries whose economies depend on natural resources have had mixed} experiences with stabilization funds. Apart from Norway and Alaska, ${ }^{8}$ funds have usually not fulfilled the expectations of their creators. ${ }^{9}$ In several cases, the countries adopted rigid rules for depositing assets into and withdrawing them from the fund, which meant that the assets accumulated while budget deficits required financing, either domestic or external. Often, funds could not withstand the political pressure to use assets when natural resource prices were higher than their historical averages. If depleted, stabilization funds could not fulfill their role when resource prices slumped. In several countries, funds also developed lives of their own taking over budgetary functions by financing "national priority" investment projects.

\footnotetext{
${ }^{5}$ See for example Engel and Meller (1993), Hausmann and Rigobon (2003), and Caballero (2000).

${ }^{6}$ Arrau and Claessens (1992), Valdès (1993), Daniel (2003). Interestingly, a third option to reduce revenue volatility does not seem to attract much attention: governments could design fiscal regimes for private oil companies such that the companies rather than the governments shoulder the price risk.

${ }^{7}$ In principle, governments can print money when resource revenue falls short of expectations. Printing money would not, of course, enable the government to buy foreign goods and would also trigger domestic inflation and currency depreciation. After creating a short-lived illusion, the government would be worse off than before. This option for dealing with revenue uncertainty is therefore not discussed in the literature.

${ }^{8}$ It should be noted that funds in Alaska and Norway and as well as some other countries, including Kuwait and Oman, have also been set up to hold oil revenue for future generations to ensure intergenerational equity.

${ }^{9}$ See Davis and others (2001).
} 
19. The literature therefore provides clear guidance on the design of such funds. Most importantly, experience has shown that effective stabilization funds are fully integrated in the budget and are not based on specific rules that determine the accumulation of assets in or their withdrawal from the fund. Instead, changes in fund assets are derived from the difference between oil revenue and the non-oil primary balance. The question therefore is how to determine the level of expenditure.

20. Assuming that holding assets in a stabilization fund is costly (the interest earned on the assets is less than the return the government could derive from an alternative use of those assets), the government maximizes utility, which it derives from spending, under uncertainty over income and facing a borrowing constraint. While the maximization problem is straightforward, its analytical solution is not.

21. Monte Carlo simulations can indicate the level of assets the government should hold in a stabilization fund. The model presented in Arrau and Claessens (1992) derives precautionary savings from utility maximization over two periods, with each period representing one month. Using plausible parameters for risk aversion and interest rates, the Monte Carlo simulations show that about 40 percent of a government's monthly earnings would be held in a stabilization fund. Their analysis does not explicitly impose fiscal stabilization; rather fiscal stabilization is a result of spending and saving decisions in each period. The spending path in the simulations is less volatile than revenue, showing the extent to which the stabilization fund is successful.

22. This chapter is not based on an explicit maximization model, but instead imposes a simple fiscal policy rule from the outset to stabilize the non-oil primary balance and takes into account a longer time horizon. Rather than determining the optimal level of stabilization and fund assets, it focuses on making explicit the trade-offs between stabilization and costs and on providing a more intuitive approach to determine how much is enough. The results compare well with those of Arrau and Claessens: although it is proposed here that a stabilization fund should have a higher level of assets than what they derive, the path of spending is also more stable.

23. The literature on stabilization funds makes little mention of the relationship between the government's liquidity and the central bank's international reserves. Research on reserve adequacy has not examined stabilizing fiscal spending when government revenue depends on volatile international prices. ${ }^{10}$ Studies on reserve adequacy in the $1960 \mathrm{~s}$ and 1970s focused mainly on the current account and yielded the rule of thumb that reserves should cover three months of imports. Following the financial crises of the late 1990s, the literature focused on the risk of a currency crisis stemming from sudden capital flow reversals. It is based on the Baumol-Tobin inventory model with fixed costs of depleting and

\footnotetext{
${ }^{10}$ See, for example, Frenkel and Jovanovic (1981) and Flood and Marion (2002) for a recent review.
} 
replenishing reserves and has yielded a new rule of thumb, coined by Federal Reserve Chairman Alan Greenspan (1999), that reserves should fully cover short-term foreign liabilities. $^{11}$

\section{Stabilizing Fiscal Spending}

24. Policymakers need to determine what level of non-oil deficit can be maintained over time. As discussed in the appendix, however, a sizable body of literature looking into the behavior of oil prices concludes that they are subject to large shocks and have a very weak tendency to revert to a mean. For practical purposes, today's price is therefore the best predictor of tomorrow's, and no medium- or long-term mean can be determined to anchor government spending. A fiscal policy based on a long-term oil price would, at some point, lead to either large deficits, the depletion of stabilization assets, and the accumulation of debt or to the accumulation of very large financial assets, which would be hard to justify in poor countries.

25. Because year-to-year oil price volatility can be quite large, a fiscal policy based on oil prices in the previous year would transmit oil price swings to the economy with a one-year lag. The resulting "boom-bust" cycles have been observed in many oil-dependent countries in the past. To avoid such cycles, fiscal spending should instead be anchored on a slow-moving, medium-term budget oil price. ${ }^{12}$ A trade-off exists between fiscal stabilization and the errors made in projecting oil prices: the more fiscal spending is delinked from oil revenue, the higher the likelihood of fiscal deficits and surpluses. This section illuminates the trade-off by showing forecasting errors and forecast volatility for different degrees of stabilization.

\section{Forecasting errors}

26. A moving average of past oil prices provides a possible medium-term anchor for fiscal policy. Table 1 compares different time spans over which the moving average can be determined. It shows the errors that would have been made in projecting oil prices using moving averages over one to nine years. ${ }^{13}$ For example, projections based on a moving

\footnotetext{
${ }^{11}$ Jeanne and Rancière (forthcoming, 2005) develop a maximization model with costs of reserves (interest rate differential) and risk aversion given a probability of facing a financial crisis. The results support the "Greenspan rule."

${ }^{12}$ Fiscal policy would be based on an oil price rule, that is, it would target a balanced budget at the budget oil price. Actual oil prices higher or lower than the budget oil price would lead to surpluses or deficits. This policy is equivalent to choosing a stable non-oil balance.

${ }^{13}$ The table calculates the root of the mean of squared differences between moving averages over one to nine years and actual prices.
} 
average over the preceding four years would have diverged from actual prices by an average of US\$10.2 per barrel for the period 1861-2003.

Table 1. Root Mean Squared Errors for Price Projections Based on Moving Averages, 1861-2003

\begin{tabular}{lrrrrrrrrr}
\hline & \multicolumn{8}{c}{ Averaging period, number of years } \\
& 1 & 2 & 3 & 4 & 5 & 6 & 7 & 8 & 9 \\
\hline Errors (in U.S. dollars) & & & & & & & & \\
$\quad$ Full sample & 9.1 & 10.9 & 11.5 & 10.2 & 9.7 & 9.9 & 10.3 & 10.9 & 11.7 \\
$\quad 1970-2003$ & 10.6 & 12.1 & 13.5 & 14.9 & 14.9 & 15.9 & 17.3 & 18.5 & 19.8 \\
\hline
\end{tabular}

Sources: BP Statistical Review of World Energy, author's calculations.

27. The same projections over the period 1970-2003 would have missed actual prices by an average of $\$ 14.9$ per barrel. ${ }^{14}$ The errors are smallest in the first column, that is, when the previous year is used to project prices. The longer the averaging period, the greater the error, at least in the volatile world following the nationalizations and ascent of the Organization of Petroleum Exporting Countries (OPEC) in the 1970s. This finding is consistent with the near-random-walk properties of oil prices: last year's price is the best predictor of today's, as shown in the first column of Table 1.

\section{Forecast volatility}

28. If, however, the random walk price rule - this year's price is used to project next year's revenue - were followed, the volatility of fiscal spending would be high. Table 2 shows average year-to-year changes in oil prices, projected by using moving averages.

Table 2: Changes in Projected Prices, 1861-2003

\begin{tabular}{|c|c|c|c|c|c|c|c|c|c|c|}
\hline & & \multicolumn{9}{|c|}{ Moving average over number of years } \\
\hline & & 1 & 2 & 3 & 4 & 5 & 6 & 7 & 8 & 9 \\
\hline \multicolumn{11}{|c|}{ Change from previous year (in percent of previous year's price) } \\
\hline \multirow[t]{2}{*}{ Full sample } & Mean & 20.3 & 14.6 & 10.9 & 8.1 & 6.5 & 6.0 & 5.8 & 5.5 & 5.2 \\
\hline & Standard deviation & 27.9 & 20.1 & 14.4 & 9.6 & 7.8 & 7.0 & 6.4 & 6.1 & 5.8 \\
\hline \multirow[t]{2}{*}{$1970-2003$} & Mean & 24.8 & 17.8 & 14.8 & 12.9 & 11.2 & 10.7 & 10.3 & 9.7 & 9.1 \\
\hline & Standard deviation & 40.1 & 24.5 & 17.5 & 15.0 & 12.7 & 11.3 & 10.3 & 9.5 & 8.9 \\
\hline
\end{tabular}

Source: BP Statistical Review of World Energy, own calculations.

29. It shows that the prices projected using, say, a four-year moving average change by 8.1 percent of the previous year's price, on average, with a standard deviation of 9.6 percent. Obviously, the longer the averaging period the lower the volatility of projected prices, but averaging beyond about five years does not seem to lead to substantial reductions

\footnotetext{
${ }^{14}$ Prices have become more volatile since the 1970 s.
} 
in volatility. ${ }^{15}$ The higher oil price volatility since the 1970 s is reflected in Table 2 in the higher mean and standard deviation of changes compared to the full sample period 18612003.

30. In conclusion, forecasting errors and forecast volatility suggest that fiscal spending guided by an oil price rule based on a moving average of three to five years provides an adequate level of stabilization, while forecasting errors would be relatively small. ${ }^{16}$

\section{Model Description}

31. Randomly generated oil prices are fed into a fiscal policy model to produce changes in stabilization fund assets over time. The probability that stabilization fund assets are exhausted in any year during the simulation horizon is then computed over a large number of model runs.

\section{The assumptions in detail are as follows:}

32. Based on regression results, oil prices are modeled using an AR(1) process in logarithms. The current oil price depends on last year's price and a random variable,

$$
P_{t}=\alpha+\beta P_{t-1}+\varepsilon_{t}
$$

where $\alpha=0.802$, and $\beta=0.703$, as shown in the appendix. Time series of 5,10 , or 15 years' duration are produced 5,000 times starting with actual 2004 prices of oil. Government spending $E_{t}$ is set equal to projected non-oil revenue, $\hat{R}_{t}^{\text {non-oil }}$, plus oil revenue, $\hat{R}_{t}^{\text {oil }}$, at the projected oil price: ${ }^{17}$

$$
E_{t}=\hat{R}_{t}^{\text {non-oil }}+\hat{R}_{t}^{o i l}
$$

33. Projected oil revenue is modeled as the taxes paid on production value, which is calculated as quantity, $Q_{t}$, times projected price, $\hat{P}_{t}$ (where quantity is assumed to be constant): ${ }^{18}$

${ }^{15}$ Of course, a maximization model would, in this case, choose the optimum level of stabilization given the costs of holding more assets in a stabilization fund.

${ }^{16}$ Venezuela and Chile determined deposits in their stabilization funds on the basis of moving averages of commodity prices, see Arrau and Claessens (1992), Claessens and Varangis (1994), Davis and others (2001).

${ }^{17}$ Non-oil revenue is assumed to be predictable.

${ }^{18}$ Stochastic development of production capacity would complicate the analysis. Risks would obviously increase. Although rising production over time would reduce the risks. Stochastic development also assumes that taxes are a constant fraction of production value, which is a 


$$
\hat{R}_{t}^{o i l}=\tau \hat{P}_{t} Q_{t}
$$

The projected oil price, or budget reference price, for each year is set equal to the preceding year's price (MA 1), or moving averages over the preceding three, five, or seven years ( $M A$ $3-7)$. In each year, the randomly generated oil price leads to oil revenue that is higher or lower than projected, and, therefore, an overall surplus or deficit. Assets in the stabilization fund at the end of each year, $A_{t}$, rise or fall with the budget balance:

$$
A_{t}=A_{t-1}+\left(R_{t}^{o i l}-\hat{R}_{t}^{o i l}\right) \text {. }
$$

34. The analysis is performed for time periods of 5, 10, and 15 years. The model has been normalized using $t_{o}=2004$ oil revenue, and initial stabilization fund assets, deposits, and withdrawals are expressed in percent of $t_{o}$ revenue. ${ }^{19}$ The model calculates the probability that stabilization fund assets are exhausted in any year during the simulation horizons.

permissible approximation only if tax-deductible production expenses are small relative to production value.

${ }^{19}$ Starting with a balanced budget in 2004, the model produces data denominated by the nonoil deficit. It should be noted that the model uses real U.S. dollars for all variables. It does not take into account exchange rate and dollar deflator feedback effects of oil prices. 
35. The simulation results show

that the probability of asset exhaustion rises with lower initial assets in the stabilization fund, a longer simulation horizon, and more stable fiscal spending or a longer moving average (Figures 1-3). The fewer the assets in the fund initially, the greater the probability that they will be exhausted during a period of low oil prices. Because of the cumulative effect of deficits, the probability of asset exhaustion rises with the length of the simulation period. And because a longer moving average increases the divergence between the budgeted and the realized price, a more stable fiscal policy requires a higher level of assets. These results are in line with the discussion in the subsection on forecasting errors and the appendix.

36. If initial asset levels are low or zero, however, fiscal smoothing through the use of moving averages reduces the risk of a crisis, the opposite of what we observe when initial assets are moderate to high. The result is due to the slow change in fiscal policy that results from using moving averages, which allows some assets to build up in "good" years when there had been no assets before. As a result, "bad" years later on in the simulation period can be smoothed over. In contrast, "bad" years early on lead to a crisis no matter which smoothing strategy is used. When using last year's oil prices (moving average of one period), fiscal policy instead allows little room to build up assets, and short "bad" spells lead to a crisis irrespective of when they occur. On balance, therefore, using a moving average over longer periods reduces fiscal vulnerability to "bad" spells, when

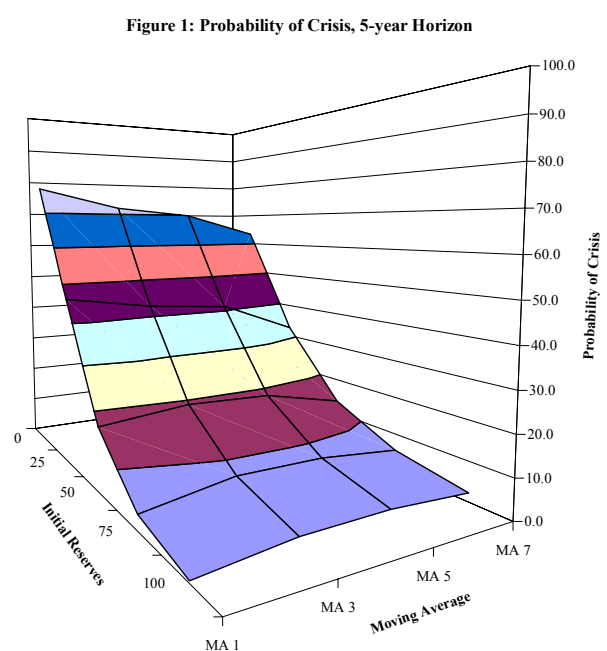

Figure 2: Probability of Crisis, 10-year Horizon

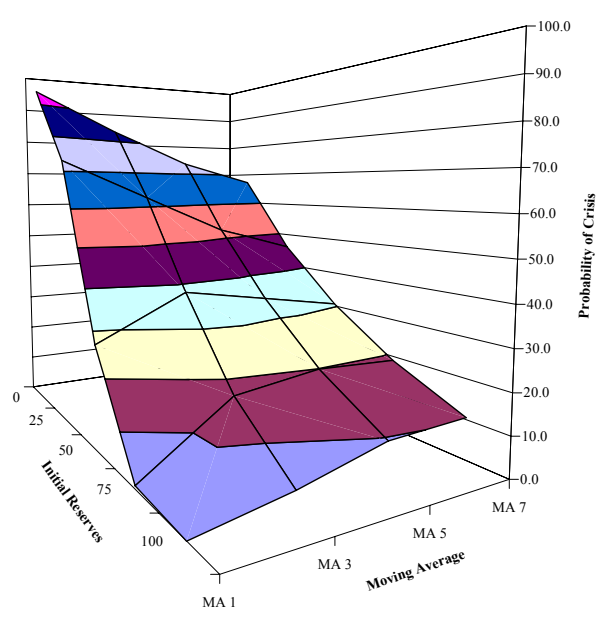

Figure 3: Probability of Crisis, 15-year Horizon

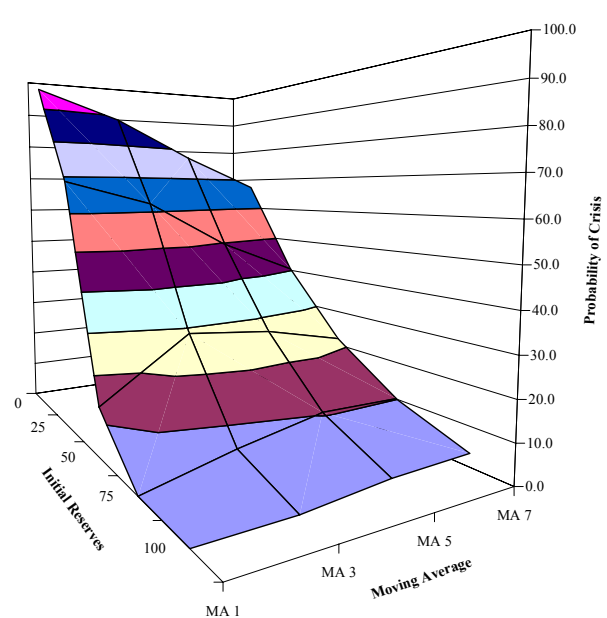


the fund has few initial assets. Alternatively, a government can base its fiscal policy on deliberately low oil prices to attempt to build assets rapidly until it accumulates enough to move to fiscal policy based on a three-to-five-year moving average.

37. In conclusion, the analysis shows that governments should best pursue a prudent and stable fiscal policy aimed at building up financial assets in a stabilization fund if initial assets are very low. Only then should they try to base their spending on a more realistic projection of oil revenue while keeping in mind the need for stabilization, for example, by basing spending on a three-year moving average of oil prices. Stabilization fund asset levels of about 75 percent of 2004 oil revenue provide adequate insurance against oil revenue shortfalls, allowing governments to adhere to their envisaged fiscal strategy.

\section{E. Application to Nigeria}

38. Nigeria's federal government followed a fiscal rule for the first time in 2004. It deposited in the central bank the oil revenue it received from prices above US\$25 per barrel. The federal authorities obtained informal cooperation from state and local governments, which then also deposited their share of windfall revenue. The federal authorities are now proposing a fiscal responsibility bill that entails formally adopting a fiscal rule that would be binding on all three tiers of government and creating a stabilization fund.

\section{Nigeria's federal government budget for $\mathbf{2 0 0 5}$ is based on a budget reference} price of US\$30 per barrel. Although the process that led parliament to choose this price is not clear, it is consistent with a moving average of oil prices over the past three years. In 2004, the budget reference price was $\$ 25$ per barrel, consistent with a moving average over four years (Figure 4). ${ }^{20}$ These prices are well below price projections at the time of budget formulation, and, at least in the case of 2004, actual prices. The rationale is that the government aims to stabilize the non-oil primary balance and build financial assets.

${ }^{20}$ In 2004, the federal government targeted a deficit at the reference price to be financed from repatriated looted funds, privatization receipts, and domestic borrowing. In 2005, all three levels of government are targeting deficits to be financed with about one-half of the windfall revenue deposits of 2004. Consolidated spending in 2004 was therefore more in line with the revenue Nigeria would have received had the oil price been $\$ 28$ per barrel, and 2005 spending is projected to be in line with about $\$ 33$ per barrel. 
40. The Monte Carlo simulation framework can be used to calculate the probability that the Nigerian government will exhaust its financial assets in the medium term (five years). ${ }^{21}$ We calculate three different fiscal policy rule scenarios: in the first, we assume that the authorities use a three-year moving average to determine the budget reference oil price and fiscal spending and that initial stabilization fund assets are equal to the saved windfall oil revenue earnings of 2004 (of US\$6 billion); the authorities aim at a balanced budget. ${ }^{22}$ In the second scenario, the authorities plan for a federal government deficit of 3 percent at the same reference price in line with recent practice. In the third scenario, they follow their mediumterm fiscal strategy, as expressed in the NEEDS, and project a 3 percent deficit with the price of oil at $\$ 27$ per barrel starting in 2006.

41. The Nigerian government has a 40 percent chance of depleting its assets within the next five years if it pursues a balanced budget policy at the reference oil price determined on the basis of a three-year moving average ("balanced budget" in Figure 5). The simulations that were performed in percent of 2004 oil earnings are here converted back into U.S. dollar amounts. Nigeria's 2004 oil revenue is about US\$21 billion, and the \$6 billion fiscal savings in 2004 from the previous analysis, translate into an initial asset level of about 29 percent. $^{23}$

42. If the authorities continue to target a federal government deficit of $\mathbf{3}$ percent of GDP at the reference price, the probability that they will be forced to adjust their fiscal policy stance within the next five years rises to about 50 percent (Figure 5, "3 percent deficit"). Finally, the announced medium-term fiscal stance based on a fixed reference price

${ }^{21}$ It should be noted, however, that the results will overstate Nigeria's risks because production increases that are highly likely to occur over the next 5 to 10 years are not taken into account.

${ }^{22}$ While the country had net foreign reserves of US $\$ 17$ billion at end-2004, government deposits in the blocked central bank account for windfall oil revenue amounting to US\$6 billion.

${ }^{23}$ While the Nigerian government is discussing a debt buy back with its Paris Club creditors, the analysis in this chapter takes the debt as a given; it is neither repaid using financial assets, nor can the government borrow more domestically or abroad. 
of $\$ 27$ per barrel and a federal deficit of 3 percent of GDP brings down the risk of forced adjustment to 20 percent. This result follows from a relatively low medium-term reference price compared with the 2004 oil price of \$35 per barrel (Figure 5, '\$27 medium-term'). ${ }^{24}$

43. In conclusion, the results show that the authorities' medium-term strategy, which is based on a reference oil price of $\$ 27$ per barrel, is consistent with ensuring fiscal stability over the medium term and with increasing financial assets that provide further insurance against forced adjustment later on. They also show that the oil revenue savings currently in the dedicated central bank accounts are too low to suggest that the government should target spending on the basis of realistically projected oil prices or a moving average of past prices. The government would run a high risk of being forced to abandon its intended fiscal stance. Assets of \$16-18 billion would reduce the probability of crisis within the next five years to below 20 percent, depending on the fiscal policy rule.

44. The authorities' medium-term fiscal goals (US\$27 per barrel and 3 percent deficit) aim at increasing financial assets to more than the current $\$ 6$ billion. The spending targeted in the 2005 budget exceeds what would be targeted in this medium-term fiscal strategy because envisaged spending is more in line with a price of $\$ 33$ per barrel. However, the reference price is still below the projected oil price for 2005: the World Economic Outlook projects a price of US\$49.5 per barrel based on March 2005 oil futures, while the 2004 oil price, seen as the best predictor of the 2005 price under the random walk hypothesis, was US $\$ 38$ per barrel. The budget is consistent with accumulating assets that can be used to stabilize fiscal spending in the future.

${ }^{24}$ If, indeed, the 2004 price is used as the reference price and the authorities target a balanced budget at this price, the probability of asset exhaustion rises to 43 percent. 


\section{ApPendiX: Modeling Oil Price Behavior}

45. Oil prices over the last century have exhibited considerable variability, which was eclipsed by dramatic changes (upward in 1973 and 1979, and downward in 1985), as well as sudden spikes (in 1990 and possibly 2004-05). This appendix looks at the statistical properties of past oil prices that have been used in the Monte Carlo simulations of the fiscal policy model in the main text. We reestimate some of the results of Pindyck (1999) and Engel and Valdès (2000), who argue that past oil prices can best be described by a simple autoregressive process. ${ }^{25}$ The generic form of these models links today's price to a trend, at least one lagged price, and a "white noise" random variable.

$$
P_{t}=\alpha_{t}+\delta_{t} \operatorname{Trend}_{t}+\rho_{t} P_{t-1}+\varepsilon_{t}
$$

46. Simple tests show that lags of more than one period are not relevant. Engel and Valdès test the forecasting ability of different oil price determination models, including random walk and autoregressive models. They estimate each model repeatedly using quarterly data that ended in the second quarter of the years 1994 to 1998 and forecast from the estimating sample. They then compute the root mean square error using forecast errors at horizons of one and two years.

47. They conclude that none of the models provides superior forecasting ability to a simple random walk without drift; that is, i.e. $\alpha_{t}$ is zero, the coefficient of the trend variable, $\delta_{t}$, is zero, and $\rho_{t}$ is unity. However, statistical tests confirm the significance of drift in past oil prices, with $\alpha_{t}$ different from zero, and the coefficient on the lagged oil price different from unity, as shown below.

48. Looking at real oil prices over the past 140 years (Figure 6), one wonders whether the large variations are indicative of structural changes in the oil market. In fact, the creation of OPEC, and the changes in its market management behavior over time, would lend support to the hypothesis that structural changes have occurred several times during the course of oil price history. Using dummy variables, we can test the validity of this hypothesis.

${ }^{25}$ All tests are performed using logs of oil prices. 
Figure 6: Oil Prices, 1861-2003

(In logs of real oil prices)

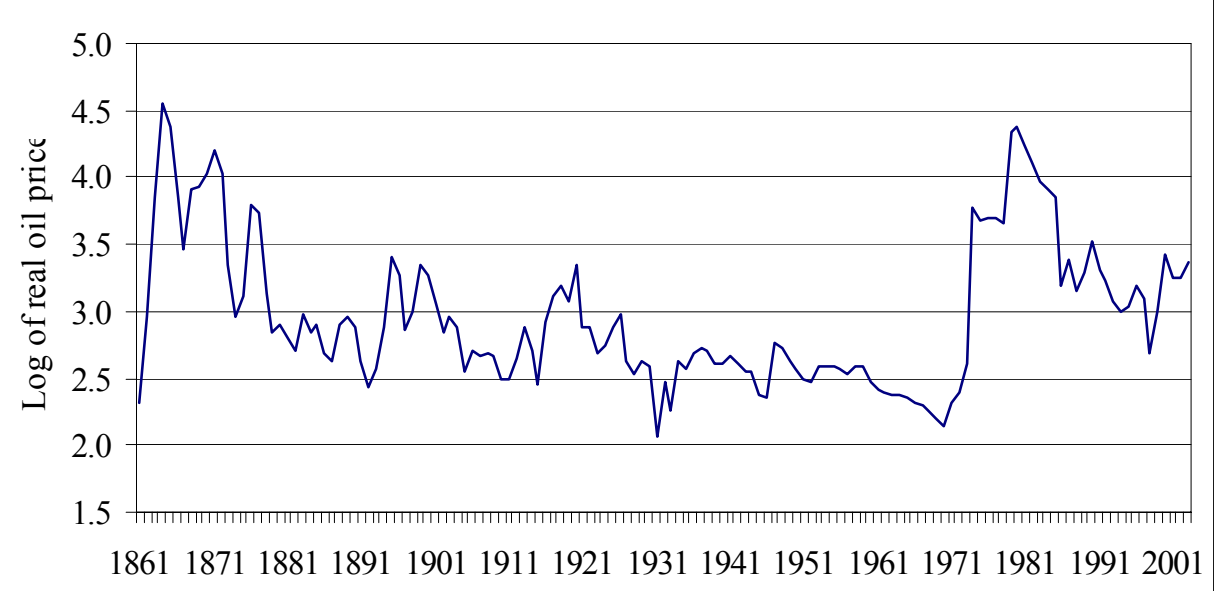

49. Simple unit root tests (augmented Dickey-Fuller, ADF) on the log of oil prices between 1861 and 2003 have been performed with different dummy variables: D1 for the period 1974 to 2003 , D2 for $1979-03$, and D3 for $1974-85 .{ }^{26}$ The tests strongly support the inclusion of a one-year lag of the oil price in a regression model, but the dummies all come short of significance at the 5 percent level, although D3 may be significant at the 10 percent level. In a linear, ordinary least squares AR(1) regression, D3 is significant at the 5 percent level and its inclusion in the model improves its fit.

${ }^{26}$ Prices started rising in 1971, but the big price increase followed the imposition of supply restrictions by Saudi Arabia during October 1973. A high point was reached in 1980, but the dramatic end to the "OPEC years" came with the decision by Saudi Arabia to move to netback pricing in the fall of 1985 . 
50. In addition, market volatility seems to have been very large during the early years shown in the series. One could easily argue that, until about the turn of the twentieth century, oil was an exotic commodity, and markets were thin and did not function well. In fact, when the period prior to 1904 was left out, model fit improved. ${ }^{27}$ Therefore, the best-fit model of oil price behavior was estimated as shown below (t-values in parentheses). ${ }^{28}$

$$
P_{t}=\underset{(5.16)}{0.8015}+0.4422 \mathrm{D} 3+0.7029 P_{t-1}+\varepsilon_{t}
$$

51. The calculated standard deviation of the regression was used to produce 5,000 series of 15 random error terms. The random terms were then plugged into the regression equation to produce 5,000 oil price series of 15 years' duration (omitting the dummy term), and the resulting logs were converted into real oil prices. Real oil prices were used in the fiscal policy model to calculate probabilities of stabilization fund exhaustion.

Figure 7: Actual and Simulated Oil Prices, 2000-19

(In U.S. dollars per barrel, in constant 2002 U.S. dollars)

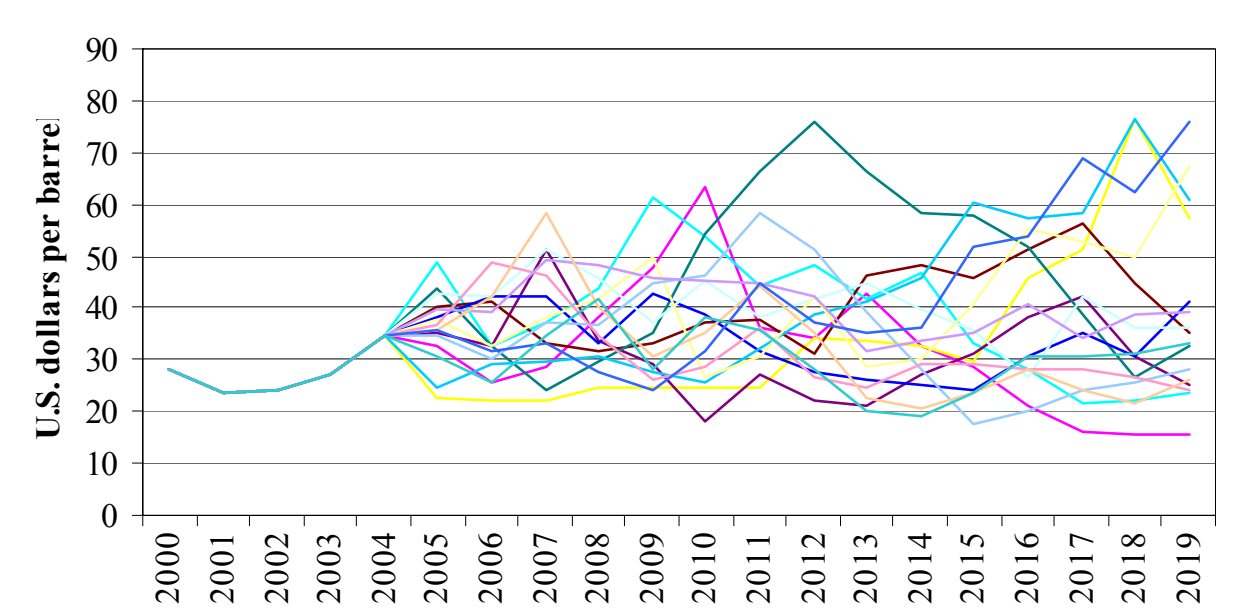

${ }^{27}$ The choice of 1904 was arbitrary, giving 100 observations for the regression.

${ }^{28}$ Other descriptive statistics:

Sigma

$\mathrm{R}^{\wedge} 2$

Log-likelihood

No. of observations

Mean $(\ln \mathrm{P})$
0.201423

0.848708

19.8641

100

2.8666
RSS

$\mathrm{F}(2,97)=$

DW

No. of parameters

$\operatorname{var}(\ln \mathrm{P})$
3.93539512

$272.1[0.000]^{* *}$

1.9

3

0.260119 


\section{References}

Arrau, Patricio, and Stijn Claessens, 1992, "Commodity Stabilization Funds," Policy Research Working Paper No. 835 (Washington: World Bank.

Caballero, Ricardo, 2000, "Macroeconomic Volatility in Latin America: A View and Three Case Studies," NBER Working Paper No. 7782 (Cambridge, Massachusetts: National Bureau of Economic Research)

Claessens, Stijn, and Panos Varangis, 1994, "Oil Price Instability, Hedging, and an Oil Stabilization Fund: The Case of Venezuela,” Research Working Paper No. 1290 (World Bank).

Davis, Jeffrey, Rolando Ossowski, James Daniel, and Steven Barnett, 2001, Stabilization and Savings Funds for Nonrenewable Resources, IMF Occasional Paper No. 205 (International Monetary Fund).

Deaton, Angus, 1991, "Saving and Liquidity Constraints," Econometrica, Vol. 59, (September), pp. 1221-48.

Engel, Eduardo, and Rodrigo Valdès, 2000, “Optimal Fiscal Strategy for Oil-Exporting Countries," IMF Working Paper 00/118 (Washington: International Monetary Fund).

Engel, Eduardo, and Patricio Meller, 1993, External Shocks and Stabilization Mechanisms, Inter-American Development Bank, Washington, DC.

Flood, Robert, and Nancy Marion, 2002, Holding International Reserves in an Era of High Capital Mobility, IMF Working Paper 02/62 (Washington: International Monetary Fund).

Greenspan, Alan (1999), Currency Reserves and Debt, remarks before the World Bank Conference on Recent Trends in Reserves Management, Washington DC, April 29, 1999.

IMF (2004), Nigeria - Selected Issues Papers and Statistical Appendix, Country Report 04/242, IMF, Washington, DC.

Jeanne, Olivier, and Romain Rancière (forthcoming), The Optimal Level of International Reserves for Emerging Market Countries: Formulas and Applications, IMF Research Department, IMF.

Krichene, Noureddine (forthcoming), Macroeconomic Fluctuations in Nigeria: A Common Trends Model Approach.

Pindyck, Robert, 1999, “The Long-run Evolution of Energy Prices,” Energy Journal, Vol. 20 pp. 1-27. 


\section{REFORMS fOr Private SECTOR-Led GROWTH ${ }^{29}$}

\section{A. Introduction}

52. The federal government of Nigeria has embarked on an ambitious and broadbased medium-term economic reform strategy (NEEDS) designed to unleash the country's enormous growth potential and significantly lower poverty. ${ }^{\mathbf{3 0}} \mathrm{NEEDS}$ aims to break away from the misguided policies and failures of the past that created an environment hostile to private sector growth. It recognizes that fundamental changes and bold reforms are necessary to address the deep-rooted structural and economic problems facing the economy and that, without them, the country will remain stuck in a trap of low savings, low investment, and low productivity.

53. This section reviews key aspects of the government's reform strategy to promote private sector growth. It also reviews briefly the country's growth performance and main growth constraints and discusses the government's efforts to improve the business environment. It concludes by drawing some policy implications.

\section{This section draws heavily on the NEEDS document, the World Bank's} Investment Climate Survey, which was completed for Nigeria in 2002, and Doing Business $^{31}$ and the Global Competitiveness Report, published by the World Economic Forum. The last three documents are largely survey-based sources but, given the dearth of information available on Nigeria, they provide invaluable insight into factors affecting business costs and productivity in Nigeria and also allow for some cross-country comparisons. $^{32}$

${ }^{29}$ Prepared by Jeanne Gobat.

${ }^{30}$ The NEEDS document can be found at http://www.nigerianeconomy.com.

${ }^{31}$ Firm-level survey data were collected from about 232 manufacturing firms of all sizes, spread across nine sectors in Nigeria. This survey forms part of the World Bank's Regional Program on Enterprise Development Survey (RPED).

${ }^{32}$ Unfortunately, significant data limitations make it very difficult to analyze factors affecting productivity in Nigeria. For example, investment is not broken down by private and public sector, or by non-oil versus oil, and few wage and employment data are available. 


\section{B. Background}

55. Nigeria's economic growth performance since independence in 1960 has been disappointing, with no significant improvement in living standards. Real economic growth averaged about $3 \frac{1}{2}$ percent between 1960 and 2002, barely exceeding average population growth. The country has also lagged behind countries at a comparable level of economic development in 1960. Most indicators of social and economic progress, including real per capita income, real per capita consumption, literacy, access to clean water, and income distribution, indicate that poverty has worsened since $1960 .^{33}$ Despite its human and natural resource wealth, Nigeria has become one of the poorest countries in the world. Per capita income in real terms was lower in 2002 than in 1975.

56. The economy has also become highly dependent on oil. Nigeria was largely an agrarian economy in the 1960 s, with agricultural output accounting for two-thirds of GDP and the bulk of export earnings and employment. It was among the world's largest exporter of key cash crops. Forty years later, it is a net importer of food, and the contribution of agriculture to the economy has declined significantly. ${ }^{34}$ With its manufacturing comprising only

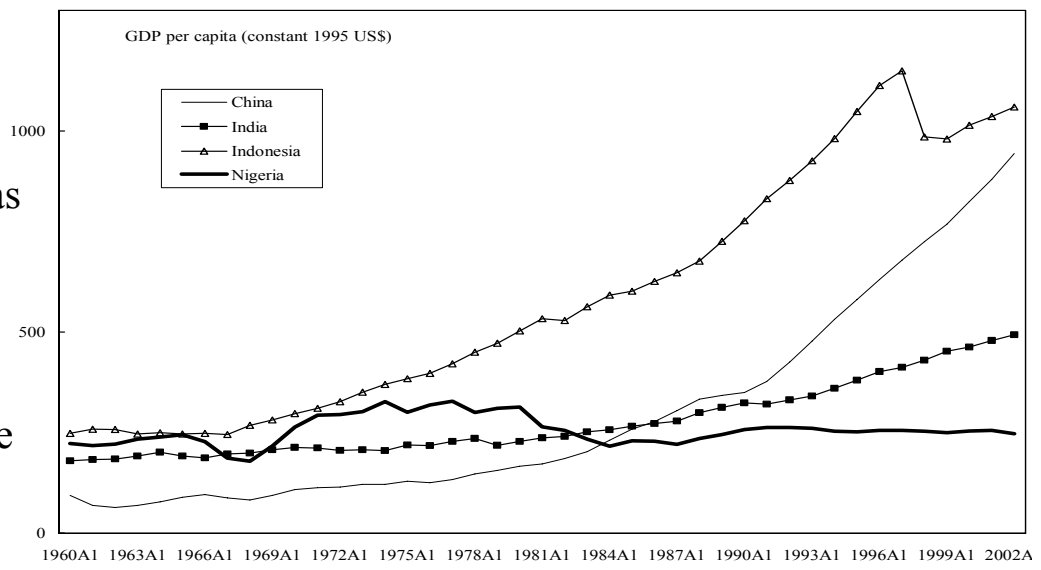
5 percent of GDP, Nigeria is also one of the least industrialized countries in sub-Saharan Africa (SSA). The decline of agricultural exports reflects a host of factors, including the impact of Dutch disease, protective trade policies, weak infrastructure, and misguided sectoral policies.

${ }^{33}$ In 1960, Nigeria's per capita income was just 11 percent below Indonesia's and exceeded India's and China's by 24 and 57 percent, respectively. In forty years, Indonesia has achieved per capita income growth four times higher than Nigeria, and China and India have also surpassed Nigeria.

${ }^{34}$ Nigeria was, in the $1960 \mathrm{~s}$, one of the largest exporters of cocoa, cotton, groundnuts, palm oil, and rubber and a net exporter of foodstuff. By the end of the 1990s, Nigeria had lost considerable export market share; imports of food products now account for about 10 percent of imports, and non-oil exports for about 5 percent of total exports. 
57. Nigeria's economy has also been highly volatile and unstable. Most macroeconomic indicators - terms of trade, real exchange rate, government investment per capita, real per capita GDP growth - display higher volatility than the average for SSA or other developing countries. The volatility stems from the country's: (a) heavy dependence on oil as a source of government revenue and export earnings; (b) highly uncertain policy environment and weak economic management, including procyclical fiscal policies, fiscal dominance, accommodating monetary policy, and frequent ad hoc

\begin{tabular}{|lcr|}
\hline \multicolumn{3}{|c|}{ Nigeria: Macroeconomic Volatility, 1961-2000 } \\
& Sample Size 1/ & Nigeria' s Rank 2/ \\
\hline Terms of trade & 90 & 3 \\
Real Exchange rate & 84 & 4 \\
Monetary growth & 125 & 32 \\
Consumer prices & 114 & 21 \\
Government revenue per capita & 71 & 3 \\
Real GDP per capita & 87 & 9 \\
\hline Source: World Bank (2003) & \\
1/ Number of countries with more than 15 observations in & \\
the period & \\
Higher ranking indicates among top country's in volatility & \\
\hline
\end{tabular}
changes to policies, including trade policy, the exchange rate regime, and business regulations; (c) social and political conflicts; and (d) ineffective financial system. Studies have shown that macroeconomic volatility has an adverse impact on growth. ${ }^{35}$

58. Despite some privatization and liberalization efforts since the early 1990s, the public sector's role in the formal economy remains substantial and has undermined the development of the private sector. Public consumption averaged 16 percent between 1990 and 2002, compared with 7 percent for Indonesia. ${ }^{36}$ There are still an estimated 1,500 public enterprises, of which state and local governments own 900 and the federal government owns the rest. In total, they account for two-thirds of formal sector employment and over half of investment. Public sector enterprise inefficiencies have significantly raised input costs and have lowered productivity in the economy.

59. The Nigerian economy, which is also relatively closed and highly regulated, has been out of step with liberalization trends taking place elsewhere in the world. The simple average tariff increased to 30 percent at end-2004 and is now one of the highest in the world. Nontariff barriers have increased in recent years with the imposition of bans not sanctioned by the World Trade Organization (WTO). Overall, foreign direct investment and the participation of foreign companies in economic activity outside the oil and gas sectors

\footnotetext{
${ }^{35}$ Bleaney and Greenway (2002).

${ }^{36}$ The public sector's share of economic activity is probably much higher if one includes spending by state-owned enterprises.
} 
have been low. ${ }^{37}$ Studies show that Nigerian manufacturing firms are more reluctant than other firms in sub-Saharan Africa to compete outside their domestic market. ${ }^{38}$

\section{Nigeria's non-oil private sector has also experienced a significant loss in}

productivity and turned in a poor investment performance. Total factor productivity contributed negatively to economic growth between 1960 and $2000 .{ }^{39}$ The negative trend growth in productivity reflects economic losses from the civil war, macroeconomic volatility, nonproductive public investment, and other institutional and policy constraints limiting efficiency gains and more productive private investment. Most of the capital contribution to economic growth came from the surge in public investment during the oil boom years and oil- and gas-related investments. ${ }^{40}$ Non-oil private investment averaged less than 7 percent of GDP between 1960 and 2000, failing to keep pace with capital

\begin{tabular}{|c|c|c|c|c|c|}
\hline & 1960-1969 & 1970-1979 & -1989 & $1990-2000$ & $1960-2000$ \\
\hline \multirow[t]{2}{*}{ Real GDP growth } & 1.4 & 7.5 & 0.4 & 3.9 & 3.6 \\
\hline & \multicolumn{5}{|c|}{ ractor growtil rales (III percent) } \\
\hline Capital & 7.1 & 11.6 & 5.7 & 2.5 & 6.7 \\
\hline Labor & 3.1 & 3.3 & 3.7 & 3.8 & 3.5 \\
\hline \multirow[t]{2}{*}{ TFP } & -3.3 & 0.9 & -4.1 & 0.6 & -1.2 \\
\hline & \multicolumn{5}{|c|}{ racior conorivuton to gowin (percentage ponnts) } \\
\hline Capital 1/ & 2.8 & 4.7 & 2.3 & 1.0 & 2.7 \\
\hline Labor 1/ & 1.9 & 2.0 & 2.2 & 2.3 & 2.1 \\
\hline TFP & -3.3 & 0.9 & -4.1 & 0.6 & -1.2 \\
\hline \multicolumn{6}{|c|}{ Sources: Staff estimates, World Bank } \\
\hline \multicolumn{6}{|c|}{$\begin{array}{l}1 \text { Assuming a Cobb Douglas production function with labor and capital shares } \\
\text { of } 0.6 \text { and } 0.4 \text { percent, respectively. }\end{array}$} \\
\hline
\end{tabular}
replacement costs and contributing negatively to non-oil GDP growth. ${ }^{41}$ This level is also well below the average of 20 percent of the world's fastest-growing economies.

${ }^{37}$ Nigeria had restrictive foreign direct investment regulations until 1995. The passage of the 1995 decree by the Nigerian Investment Promotion Commission eliminated discriminatory screening processes for foreign investment and allowed 100 percent foreign ownership of any business except those in the oil and gas sectors and in sectors deemed sensitive to national security.

${ }^{38}$ Soederbom and Teal (2002).

${ }^{39}$ It would be more accurate to calculate the TFP without the oil sector. Unfortunately, data for investment do not allow for such an analysis.

${ }^{40}$ According to government reports, many of the capital projects were never completed. In addition, public investment may be overstated as some of the reported capital spending could be capital flight or private consumption.

${ }^{41}$ This is a derived figure. Nigeria's Federal Office of Statistics provides overall investment. 
Figure 1. Nigeria: Sources of Economic Growth, 1960-2000
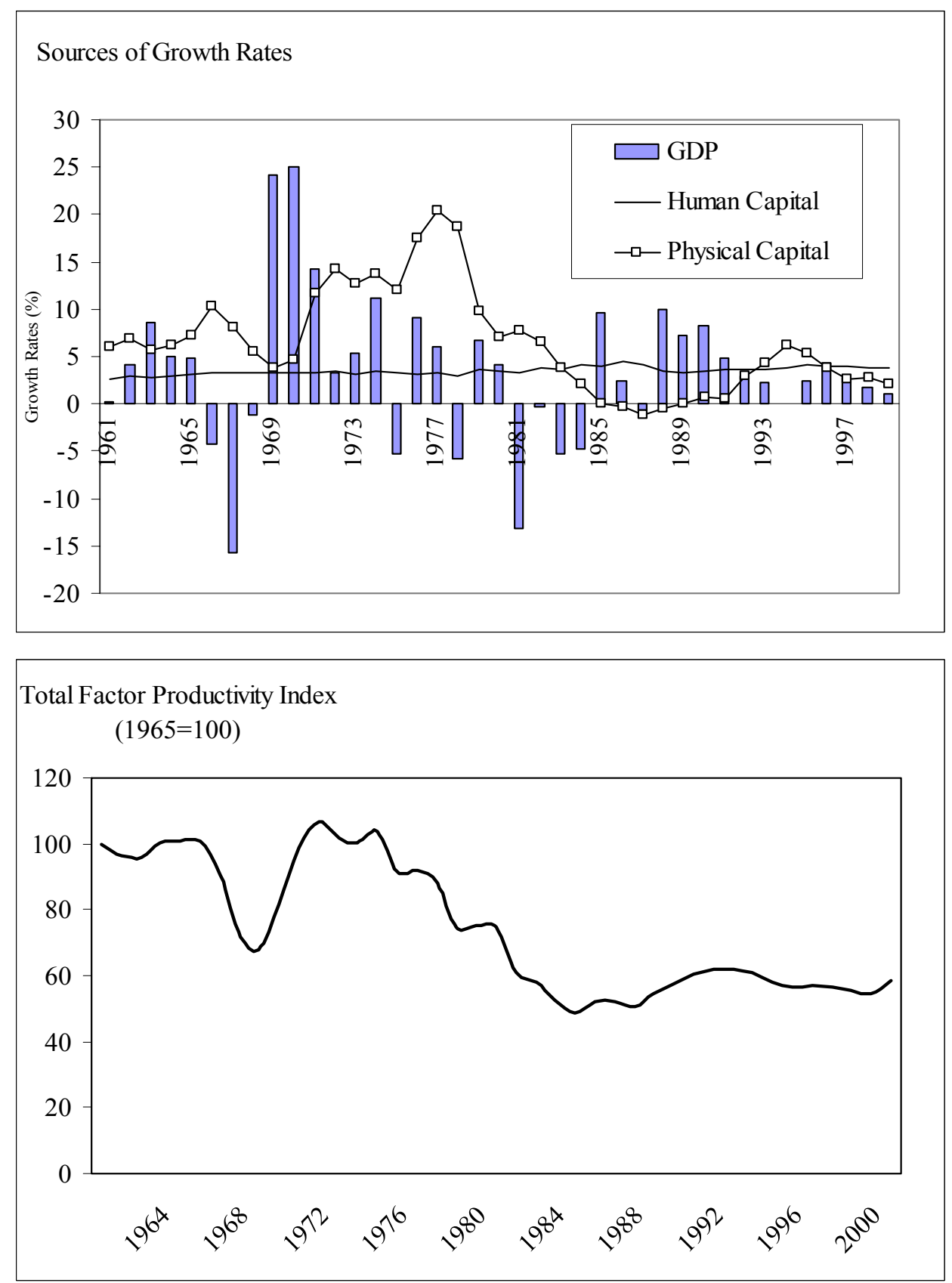

Source: Authorities, World Bank, and staff estimates. 
61. Learning from past policy failures, the authorities' main policy objectives, as described in NEEDS, are to create an environment conducive to private sector-led growth. The aim is to boost productivity growth and external competitiveness, diversify the economy away from oil, reduce the role of the public sector in economic activity, and free the business sector from government regulations, controls, and inefficiencies. One key objective is to restore the status of agriculture as the leading sector in the economy and to enhance its contribution to export earnings and employment creation. Strong growth is also expected in manufacturing and solid minerals.

62. The government aims to raise growth in the non-oil economy to 7 percent a year over the next decade. The high growth rate, necessary to halve poverty by 2015 , is very ambitious. To achieve it, real investment would have to increase by about 15 percent in real terms, requiring that national savings also increase. Total factor productivity growth would need to average about 2 percent a year over the next 10 years. ${ }^{42}$

63. The government's key strategies to achieve these goals include

- $\quad$ creating a stable and predictable macroeconomic framework

- $\quad$ privatizing state-owned enterprises

- $\quad$ strengthening institutions and governance standards

- $\quad$ improving and developing infrastructure

- $\quad$ liberalizing the trade regime

- $\quad$ reforming the judicial system and enforcing the rule of law

- $\quad$ creating competitive business regulations

- $\quad$ strengthening the financial sector

${ }^{42}$ A standard growth accounting framework was used to derive these figures. The labor force will grow at 2.8 percent a year, and, typical for a standard Cobb-Douglas production function, labor's share was assumed to be 0.6 percent. Improvements in educational attainment are captured as part of total factor productivity growth. The depreciation rate of the capital stock was set at 6 percent. See Tahari and others (2004). 


\section{Public sector governance}

64. The government considers strengthening governance and improving the quality of public institutions as the country's central reform challenge and critical to achieve higher sustainable growth and to reduce poverty. It is of the view that weak public sector institutions and poor governance principles, including a lack of transparency and accountability, are a root cause of Nigeria's weak growth record, ineffective public policies, and marginally productive public spending.

\section{International surveys confirm the poor quality of Nigeria's public institutions.}

As measured by the perceived degree of corruption, the rule of law, and enforcement of contracts, they ranked 98 out of the 102 countries assessed in the 2004 Global

Competitiveness Report. On key issues that matter to a sound investment climate - such as transparency and predictability of policies, enforcement of property rights, judicial independence, even-handed treatment of the private sector, low level of corruption and crime, quality of infrastructure and efficient bureaucracy-Nigeria ranked in the bottom 5 of the 102 countries assessed. ${ }^{43}$ While Nigeria's public school system was considered among the best in Africa in the late 1960s, 30 years later businesses ranked it as one of the worst in sub-Saharan Africa. Similarly, Transparency International's 2004 report places Nigeria next to last on its Corruption Perception Index - which assesses the degree of corruption among public officials and politicians. The World Bank's worldwide governance indicators rank Nigeria lower than most developing countries on property rights, rules-based governance, and quality of public administration and regulations.

\footnotetext{
${ }^{43}$ Although required by law, fiscal accounts, including those of state-owned enterprises, have not been audited and made publicly available on a timely basis, impairing the ability of parliament and the general public to monitor fiscal operations and hold public officials accountable.
} 
Table 1. Competitiveness Indicators--Nigeria compared to other Sub-Saharan African (SSA) Countries

\begin{tabular}{lcccccr}
\multicolumn{2}{c}{ Growth Competitiveness Indicator 1/ } & \multicolumn{3}{c}{ Public Institutions Index 2/ } \\
& SSA Rank & Global Rank & & & SSA Rank & Global Rank \\
\hline Botswana & 1 & 36 & & Botswana & 1 & 26 \\
South Africa & 2 & 42 & & Malawi & 2 & 38 \\
Mauritius & 3 & 46 & & Gambia & 3 & 39 \\
Namibia & 4 & 52 & & South Africa & 4 & 43 \\
Gambia & 5 & 55 & & Mauritius & 5 & 44 \\
Tanzania & 6 & 69 & & Namibia & 6 & 48 \\
Ghana & 7 & 71 & & Tanzania & 7 & 59 \\
Malawi & 8 & 76 & & Ghana & 8 & 65 \\
Senegal & 9 & 79 & & Zambia & 9 & 69 \\
Uganda & 10 & 80 & & Ethiopia & 10 & 73 \\
Kenya & 11 & 83 & & Senegal & 11 & 75 \\
Nigeria & 12 & 87 & Mozambique & 12 & 82 \\
Zambia & 13 & 88 & Mali & 13 & 83 \\
Cameroon & 14 & 91 & Uganda & 14 & 84 \\
Ethiopia & 15 & 92 & Zimbabwe & 15 & 90 \\
Mozambique & 16 & 93 & Angola & 16 & 91 \\
Madagascar & 17 & 96 & Kenya & 17 & 92 \\
Zimbabwe & 18 & 97 & Cameroon & 18 & 95 \\
Mali & 19 & 99 & Madagascar & 19 & 96 \\
Angola & 20 & 100 & Nigeria & 20 & 98 \\
Chad & 21 & 101 & Chad & 21 & 101 \\
\hline
\end{tabular}

Source: The Africa Competitiveness Report, World Economic Forum

1/ The Growth Competitiveness Index (GCI) uses hard data and survey data and consists of the macroeconomic environment index, public institutions index and technology index.

2/ The public institutions index is a composite of the contracts and laws sub index and corruption sub index. It uses survey data and reviews the extent of paybacks and brides that are required in dealing with the public sector as well as quality of the legal system, enforcement of contracts, as well as the cost of organized crime on business. 
Figure 2. Nigeria: Competitiveness Indicators

(Score) 1/
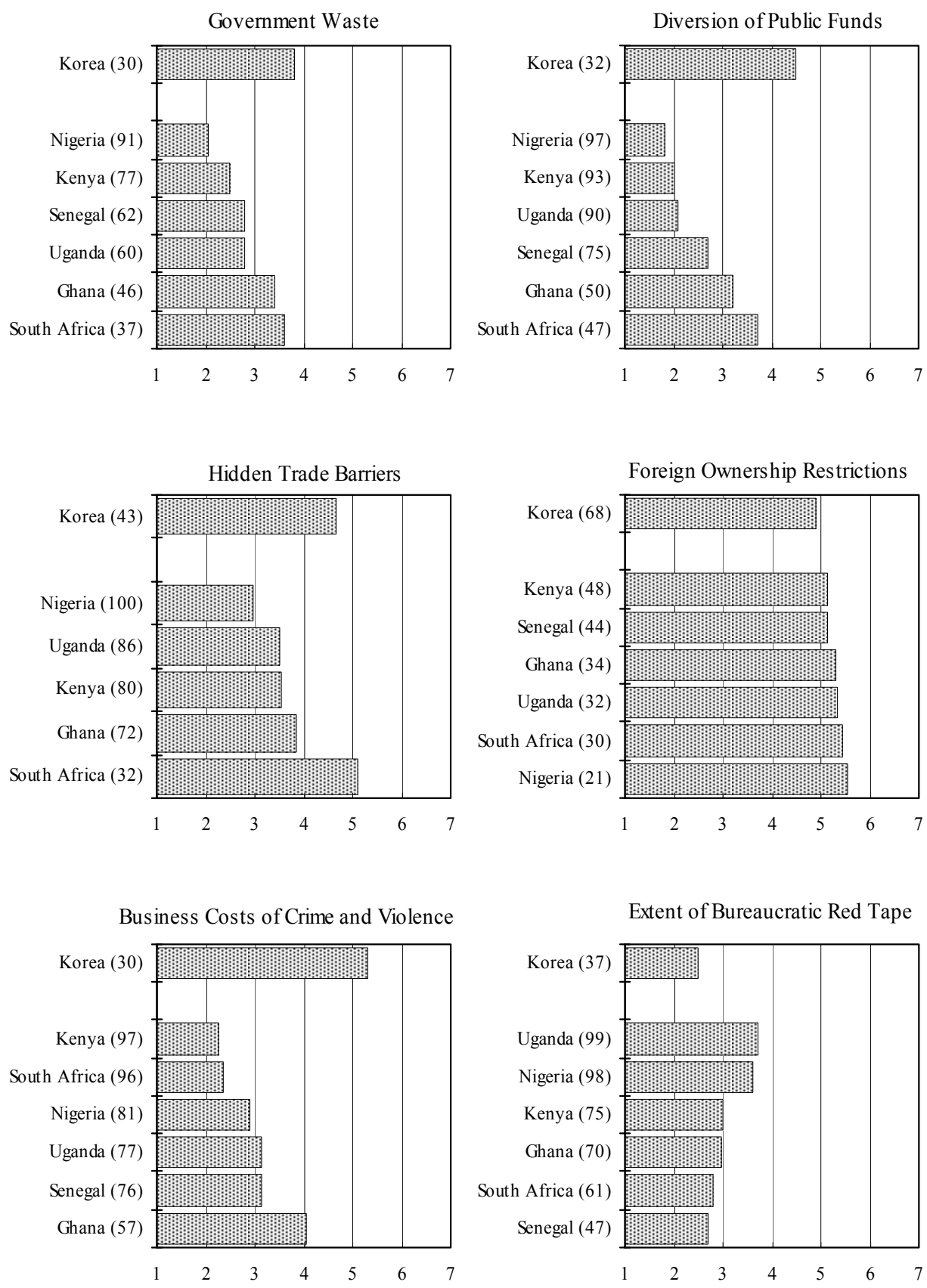

Source: The Africa Competitiveness Report, World Economic Forum

$1 /$ The numbers in paranthesis reflect the country's score out of the total 102 countries surveyed and ranked. Data reflect responses to the 2003 Executive Opinion Survey. 
Figure 3.Nigeria: Competitiveness Indicators

(Score, unless otherwise indicated) $1 /$
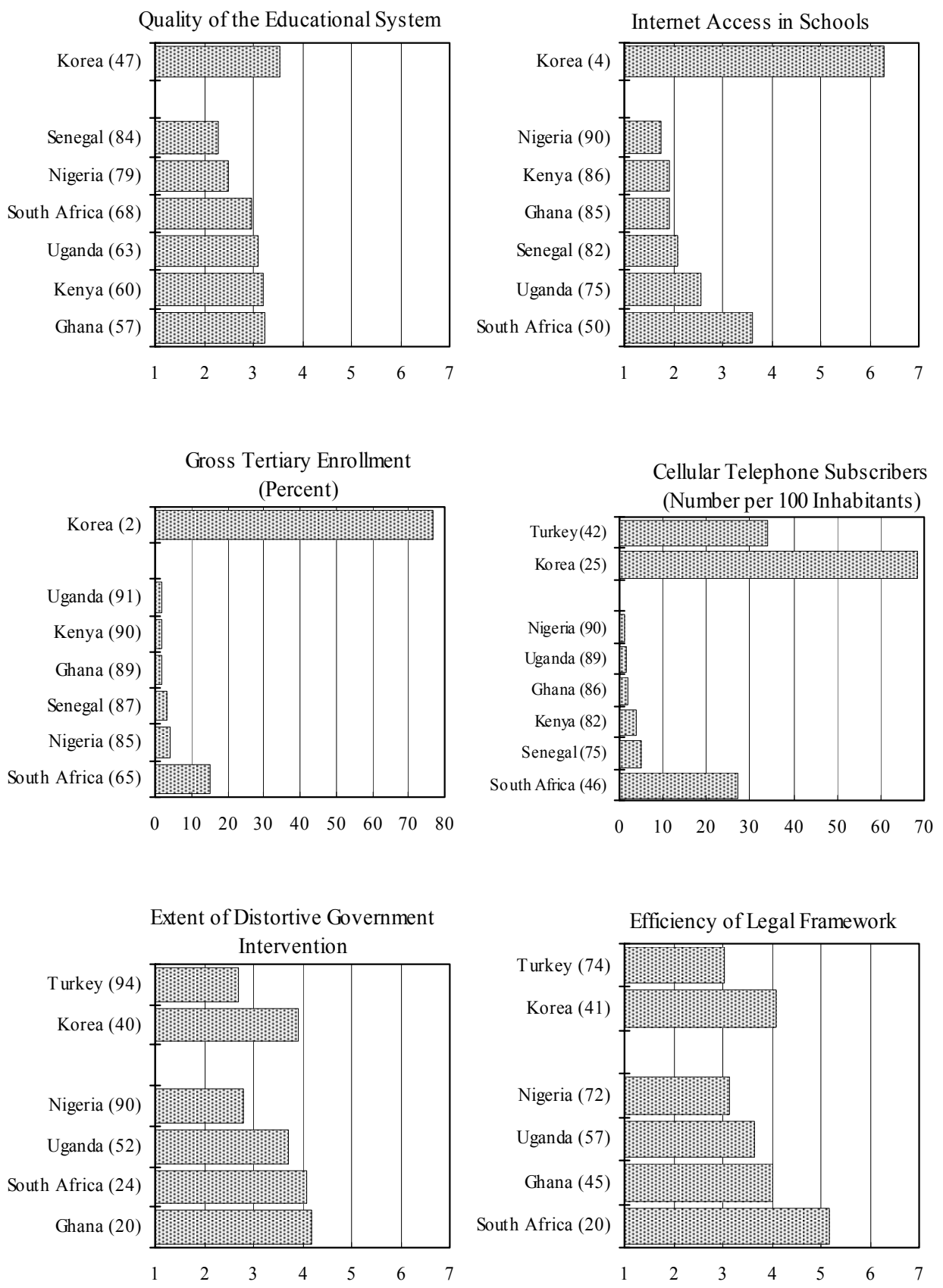

Source: The Africa Competitiveness Report, World Economic Forum

1/ The numbers in paranthes is reflect the country's score out of the total 102 countries surveyed and ranked. Data reflect responses to the 2003 Executive Opinion Survey. 
66. Firms surveyed in the World Bank's RPED cited corruption, irregular application of laws and regulations, and favoritism as major cost drivers and deterrents to investment. Rent-seeking activities were highest with establishing public utility connections, followed by license and permit processing, procurement of government contracts, customs clearance, and tax collection. With regard to the last-named item, firms indicated that they did not view the level of corporate taxation (at 30 percent) a burden but rather the harassment by tax officials. This may also explain the large presence of smaller firms in the informal sector, with estimates suggesting the informal sector accounts for as much as 40-50 percent of GDP as well as for low tax compliance.

67. A related governance issue is the problem of crime and security. According to the World Economic Forum's Executive Survey Opinion, businesses listed security and crime concerns, including theft of equipment and inventory by employees, as their sixth biggest cost driver. Firms in the World Bank's RPED survey noted that security issues were a serious concern in Lagos. Because of the frequent threat of robberies along main transportation routes, crime and security issues restrict commerce and domestic market integration. Companies also complain that security problems make it more difficult to attract highly skilled expatriates. ${ }^{44}$

68. In formulating NEEDS, the authorities have made fighting corruption, improving governance and quality of public institutions, and strengthening security its number one reform priority. The following actions have brought them closer to their goal:

- $\quad$ Nigeria has signed on to the Extractive Industries Transparency Initiative (EITI) to enhance the transparency of oil revenue management. A formal audit of the oil accounts is under way, and all results will be published. The passage of the EITI law would formally require that oil companies publish all oil- and gas-related information.

- $\quad$ The Economic Financial Crimes Commission (EFCC) has been established to fight corruption in the public sector and financial system. The passage of the anti-money laundering act in 2004 allows the EFCC to investigate and prosecute crimes committed thereunder.

- $\quad$ The government has begun publishing, on a monthly basis, revenue distributed to the three tiers of government, auditing fiscal accounts, and making audited results available on a timely basis.

- $\quad$ Main line ministries are subject to performance evaluation and reporting requirements.

${ }^{44}$ World Bank (2002). 
- $\quad$ Procurement and due process reforms, the ongoing civil service reforms, and overall efforts to streamline the government are critical to eliminating corruption, enhancing the quality of public institutions, and ensuring value for money.

- $\quad$ The police force is being strengthened and the judicial system (see discussion below) is being reformed to ensure rule of law.

\section{Physical infrastructure}

69. Nigeria's infrastructure, in terms of quality and quantity, is inferior to that in much of the rest of the world, which significantly raises the cost of doing business. ${ }^{45}$ Out of 102 countries assessed in the Global Competitiveness Report (2004), business executives ranked Nigeria's overall quality of infrastructure third to last. This outcome is consistent with the results of the World Bank's RPED survey, with manufacturing firms ranking infrastructure as their most severe business constraint. This holds true for all firms, independent of size, sector, location, or ownership (foreign or domestic).

70. Unreliable electricity is Nigeria's single largest business problem. Frequent blackouts have sharply inflated operational costs through production stoppages, output losses, and missed delivery dates. About 97 percent of the firms surveyed operated their own power generator, well above the average of 22 percent of the 55 countries surveyed in the World Bank's Investment Climate Survey. Purchasing private power generators accounted for 22 percent of firms' investment budget. Firms estimated that frequent outages caused them to lose about 85-90 working days a year, equivalent to 15 percent of their annual sales. $^{46}$

\section{Nigeria also fares poorly in other areas of infrastructure provision vital to economic development:}

- Telephone coverage is among the lowest in the world, with 0.6 lines per capita, compared with 10.2 for South Africa and 27 for Mauritius. ${ }^{47}$ The country scores low in terms of number of telephone lines and internet users and internet access in schools. Interregional variability is large, with rural areas having weaker access.

${ }^{45}$ Adequate and high-quality physical infrastructure is central to economic development. Studies have found that firms that have access to good infrastructure invest more and are more productive. See Weiss (1999).

${ }^{46}$ Only 10 percent of rural households and 40 percent of the country's population have access to electricity. Poor power service also has serious implications for the attainment of the country's health and education goals. Unreliable power has made it difficult to refrigerate vaccines and operate hospitals and also prevents children from studying at night.

${ }^{47}$ Mobile phones have started to make up for this shortcoming. 
- The port system is inefficient and costly. Lagos port is considered one of the most expensive ports in the region, with transaction costs roughly three times higher than those of any other West African port. ${ }^{48}$ It requires an average of 28 days to clear shipments, as opposed to the international norm of less than 2 days. Aside from port inefficiencies and outdated equipment and technology, key causes for the delay are the punitive trade regime, theft, and corruption in customs, which further raise the cost of importing cargo through the ports. ${ }^{49}$ The highly protective trade regime has resulted in widespread smuggling and duty evasion. In response, the authorities have instituted a 100 percent inspection requirement, which, in turn, has increased port congestion.

- $\quad$ Poor road network. The country's road density is among the lowest in Africa: 31 percent of roads are paved compared with 52 percent in middle-income countries, and only 40 percent are in good condition. Only about half of the unpaved roads are accessible in the dry season, and 40 percent of the rural communities are shut off from market-access roads. The lack of all-weather roads condemns rural areas to subsistence production and limits access to education and primary health care. A major problem has been insufficient investment, with government budgets not providing sufficient funding to complete and maintain roads. As a result, much of the investment that has taken place has lost value.

- Weak water infrastructure. About 60-70 percent of rural dwellers and 50 percent of urban dwellers lack access to adequate water supplies (including potable water) and proper sanitation facilities. A further lack of water irrigation systems in rural areas makes agriculture production more vulnerable to climatic conditions, limits opportunities to invest in higher value added crops, and overall agricultural productivity. Universal access to adequate water and sanitation services is recognized as essential to public health, individual well-being, and productive activities.

72. The weak state of Nigeria's infrastructure reflects a host of factors, including neglect, misguided policies, lack of competition and private sector involvement, weak capacity for selecting and administrating projects, and political interference and corruption. Licensing and other government entry restrictions prevented private firms from competing with state monopolies in the provision of infrastructure. The government's pricing policies were also set with little regard to commercial objectives, including cost recovery and ability to operate, maintain, and rehabilitate facilities. Corruption, weak procurement practices, and a lack of public accountability resulted in a mismanagement of funds and inefficient infrastructure investments.

\footnotetext{
${ }^{48}$ World Bank (2002).

${ }^{49}$ World Bank (2002).
} 
73. Tackling infrastructure inefficiencies is a core part of Nigeria's strategy to provide an environment conducive to private sector development and poverty reduction. Active private sector partnerships will be sought in the provision of infrastructure services, key public sector enterprises are to be privatized, and the legal and regulatory framework will be reformed to encourage competition and protect consumer welfare. Where necessary, the government will scale up funding for rehabilitation and expansion of services, particularly with regard to water and roads (see Box 1). Privatization and deregulation would help create a level playing field that would encourage market entry and competition.

\section{Business regulations}

74. Firms in Nigeria grapple with costly administrative procedures and regulations, excessive red tape and rent-seeking activities by public officials wanting to establish and operate businesses in Nigeria. According to Doing Business (World Bank, 2005), to start a business, a firm in Nigeria is expected to go through at least 10 bureaucratic procedures and wait an average of 44 days; in contrast, a firm in one of members of the Organization for Economic Cooperation and Development (OECD) faces an average of 6 procedures and a 27-day waiting period. ${ }^{50}$ A firm must also deposit capital equivalent to at least 60 percent of per capita income in Nigeria to establish a limited liability company, as required under the Company Law (the Companies and Allied Mattes Act). Many countries, seeking to spur small business start-ups, have scrapped this

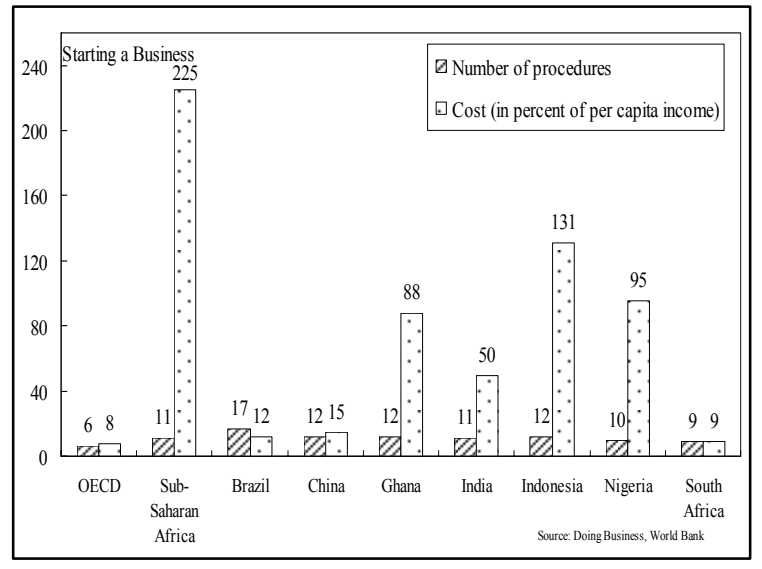
requirement.

75. Routine business applications in Nigeria are slow and costly, and firms complain that poor government services add considerably to the cost of doing business. ${ }^{51}$ The administrative process is further complicated by the federal system with its overlapping jurisdictions and procedures. Companies are frequently required to pay new, arbitrary local taxes and fees, clarify plans, and submit additional documents to local government officials. All these hurdles and extra payments raise production costs and lower profitability,

${ }^{50}$ Foreign companies have to go through additional steps, including registering with the Nigerian Investment Promotion Commission (NIPC), which they must do every year in the state in which they will operate; provide background information on company officers, and proof of share capital deposited with a local bank; and provide information on training programs for local personnel. They also face a quota restriction in hiring expatriates.

${ }^{51}$ World Bank (2002). 
discourage market entry, and weaken competition. The heavy-handed business procedures also imply opportunities for officials to extract bribes and tend to disadvantage small and medium-sized enterprises. ${ }^{52}$

\section{Box 1. NEEDS--Infrastructure Reforms}

- A major reform of the power sector is under way. A new power bill signed into law in March 2005 will facilitate the unbundling of the national power company into 18 transmission, generation, and distribution companies and encourage private participation and investment. The Nigerian Electricity Regulatory Commission (NERC) will be established to ensure a level playing field and consumer protection. Independent power producers will be allowed to generate and sell electricity. The government will focus on improving transmission lines and encourage the utilization of gas through price and other incentives. The introduction of a new collection method has already helped improve collection rates to 75 percent compared with 20 percent a few years ago. New power plants are also being built and should increase generation to 10,000 megawatts by end-2007 from 2,500 megawatts currently. Finally, the national rural electrification program aims to connect the remaining 96 local governments to the national grid by end- 2005 .

- The transportation sector is being reformed. The passage of a draft transportation bill will establish new regulations and allow private participation in the management of ports, railways, and airports. A major port reform is under way with the aim of increasing the role of Nigeria's seaports in the shipping sector within the region. Private companies will be granted long-term concessions in all government-owned ports. This, along with the customs administration reform and trade liberalization, should help expedite the movement of cargo.

- The federal government has increased budgetary resources considerably for the completion of unfinished road projects and for road maintenance. The ongoing construction of 3,000 kilometers of roads will be completed before the government embarks on new projects. The federal government is also coordinating with subnational governments about the order of priority of road projects. A federal road maintenance agency has been established to oversee road maintenance and involve private sector participation. In general, improved access to paved roads would allow farmers to move their goods to bigger markets more cheaply, making land and farming more productive and profitable. Paved roads would also improve primary school enrollment and health care access.

- The national telecommunication company is slated for privatization in $\mathbf{2 0 0 5 / 0 6}$. The sector's performance has already improved dramatically with the introduction of cellular telephony and opening of this segment to private sector competition, including foreign operators in 2001. At end2004, there were over 9 million cellular phone subscribers.

- The government has launched the National Water Supply and Sanitation Policy, which aims to make safe drinking water available to at least 60 percent of the population. Budgetary resources at all levels of government have been increased, and a national system to ensure the quality of water is being developed, consistent with the standards of the World Health Organization.

${ }^{52}$ Morrisset and Neso (2002) and Djankov and others (2005). 
76. Companies also pay high costs to obtain foreign exchange. The current regulatory regime governing foreign currency transactions is cumbersome: applications for foreign exchange have to be approved by the Central Bank of Nigeria in accordance with foreign exchange control regulations. Nigeria is, furthermore, among a handful of economies remaining that still maintain multiple foreign exchange markets.

\section{The government aims to streamline the business registration process by} simplifying forms; cutting the number of procedures; transforming the NIPC into promoter and facilitator rather than regulator; eliminating the FDI registration process through the NIPC; streamlining tax forms, requirements and incentives; and doing away with site visits. The authorities also plan to streamline foreign exchange documentation requirements and unify the official foreign exchange market. The government is currently overhauling both tax and customs administrations to streamline tax procedures, improve the quality of service provision,

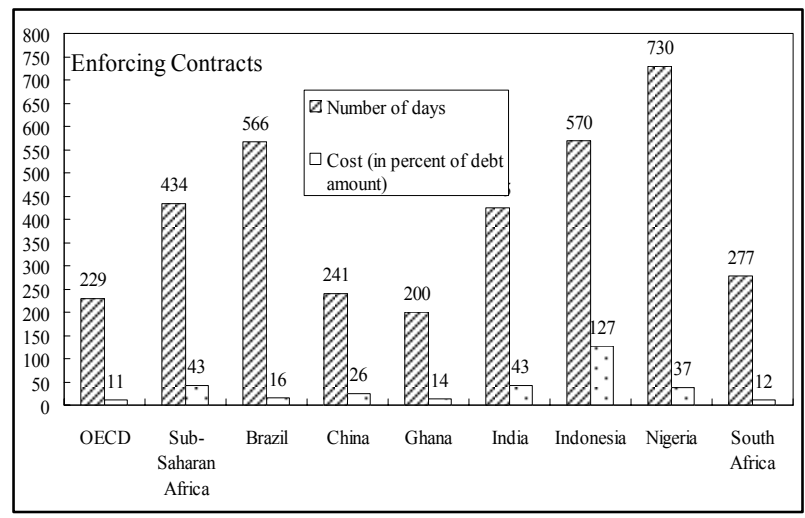
expedite trade facilitation, and broaden the tax base. These reforms, however, call for strong coordination with subnational governments to avoid overlapping functions and costs.

\section{Business legal environment}

78. Although, on paper, Nigerian laws are largely adequate, they are not adequately enforced and the courts are considered debtor-friendly and inefficient. ${ }^{53}$ Creditors usually find themselves in costly and lengthy litigation because debtors can easily obtain court injunctions to avoid repaying their debts. Cross-country comparisons show that Nigeria's court procedures are among the slowest and that commercial cases take a long time to resolve. It takes, on average, over 2 years, 23 procedures, and one-third of the debt amount to enforce a debt contract in Nigeria. Creditors and firms are consequently reluctant to consider the courts a meaningful option for loan recovery or dispute resolution. They tend to seek out-of-court options, even frivolous ones, because of their lack of faith in the efficacy of the judicial system.

\footnotetext{
${ }^{53}$ Nigeria's bankruptcy laws (Bankruptcy Act of 1979) are based on U.K. laws. Corporate bankruptcies and the use of receiverships or administrators to manage businesses during reorganization or liquidation are not uncommon in Nigeria. Less common are personal bankruptcies.
} 
79. Foreclosure procedures are also cumbersome in Nigeria. Asset recovery and liquidation come at considerable cost. The rate of recovery, for example, is about 33 percent. The cause of court delays and low recovery rates are manifold: weak court procedures, such as making it easy for debtors to appeal; a lack of specialized commercial courts or small claims court, backlogs, frequent power failures resulting in court adjournments; a low level of technology; and too few judges who can prosecute corruption.

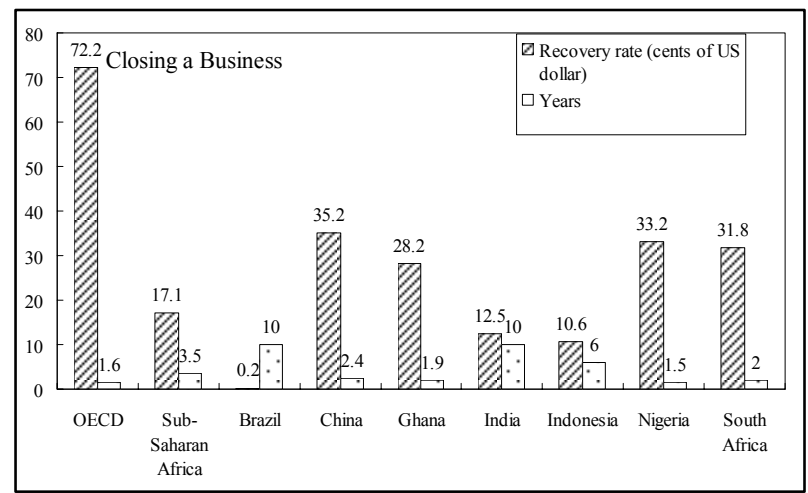

\section{The NEEDS document takes into} account shortcomings in the judicial system and the fact that after 30 years of military rule the system no longer offers a reliable basis for dispute resolution, protection of property rights, and enforcement of contractual rights. Judicial reforms will include training judges, improving court facilities, developing an alternative dispute resolution mechanism, and creating commercial courts.

\section{Lagos State, which accounts for the bulk of the country's commercial and}

financial activity, has been at the forefront of judicial reform. Since the return of civilian rule in 1999, the state has appointed over 25 young professional judges and has established a specialized commercial court to resolve commercial disputes expeditiously. The salaries of judges have been increased to attract qualified candidates and remove incentives for corruption. Furthermore, court infrastructure is being strengthened through the acquisition of computer facilities, the construction of law libraries, and the hiring of legal assistants. With donor assistance, efforts are also under way to update court procedures, such as through the introduction of modern case management techniques and simplified pretrial procedures. Similar reforms will be needed in other state jurisdictions to enhance the efficacy of the courts. 


\section{Registering and transfering property}

\section{According to Doing Business, Nigeria's regulations for registering and} transferring property, which are among the most cumbersome in the world, comprise 21 procedures, 27 percent of the property value in official fees, and a registration period of 274 days. These procedures reflect the institutional arrangements governing land ownership and transactions in Nigeria. According to the Land Use Act of 1978, all land in a state is vested solely in the governor of that state, who must consent to requests to sell, lease or mortgage the land. ${ }^{54}$ Although in practice, consent is readily given, the process is slow, costly, and associated with heavy rentseeking activities. In Lagos State, the fees associated with obtaining governor consent amount to 30 percent of the market value of the land. In addition to these costs, there are

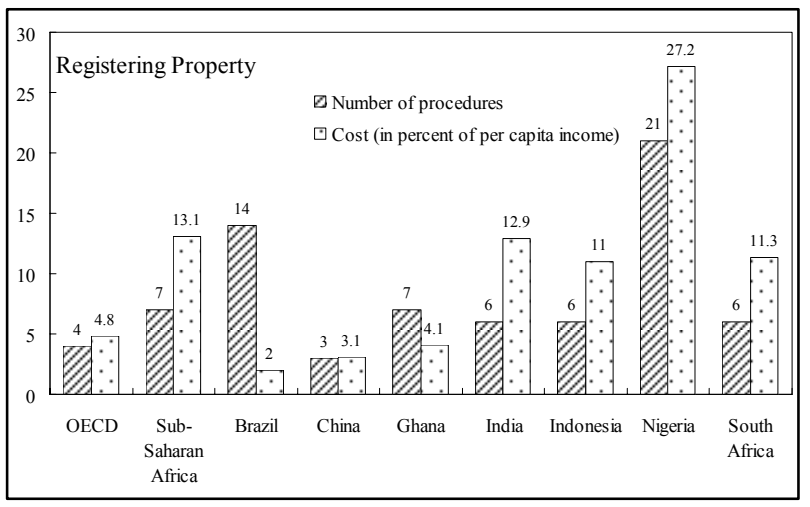
registration fees, taxes, and legal fees. Permission to lease land and use it as collateral must be approved separately. Registering collateral can take from six months to two years.

83. The property registration system is also poorly managed, and few records are kept of plot allocations and transfers. This problem is further exacerbated by large, unrecorded informal property transactions that take place to avoid the formal system. As such, land titles do not provide full security of ownership and can be contested in the courts or by state governors.

84. Land reform, an important component of the NEEDS, is viewed as central to wealth creation. It is also seen as increasing investment; improving credit access; spurring innovation in financial products, such as mortgages and term lending; and developing a private real estate market. The reforms aim to reduce documentation requirements and fees for individuals purchasing and registering property, establish transparent site visit protocols and processing deadlines, develop a registry system of plot allocation and transactions, provide easier access to information in the registry, and create a data bank of property registries. The policy governing stamp duty will also be reviewed.

85. The Federal Capital Territory (FCT) has taken the lead in reforming its land registry system and privatizing state-owned land. So far, it has computerized all land records and, in the process, has uncovered significant forgeries of certificates of title and multiple ownerships. It is now validating more than 50,000 plots allocated over the past two

\footnotetext{
${ }^{54}$ When land is allocated, the recipient receives a certificate of occupancy for a period of up to 99 years. The certificate entitles the person, with the consent of the state governor, to sell, lease, or mortgage the land.
} 
decades. Once completed, the FCT will begin selling off public houses and land with the aim of spurring the development of a private real estate market. Comprehensive land reform will require a review of the 1978 Land Use Act and the full cooperation and participation of all state governors.

\section{Financial infrastructure}

\section{Overall, the Nigerian financial system has not fostered stability or supported} investment and economic development. The financial system is underdeveloped, and the level of financial intermediation, as reflected in a narrow M2/GDP ratio, low private sector credit/GDP ratio, and large share of cash transactions, is low. The use of credit cards and leasing arrangements is limited. A large segment of the banking system does not have access to bank credit, and most lending is short term in the form of collateralized overdrafts. Movables such as equipment, inventory, or receivables cannot be pledged as security. Longterm bank lending is not available, and the corporate bond market is inactive. Some larger, more established firms have access to equity financing through the Lagos Stock Exchange. The underdeveloped financial system and cash-driven economy reflect a host of factors:

- The banking system is unsound. Banks continue to be plagued by unsound balance sheets and weak governance practices. The quality of their balance sheets continues to be undermined by a high level of nonperforming loans and operational inefficiencies. The 2002 Financial Sector Assessment Program (FSAP) report noted that misreporting, systemic underprovisioning, widespread insider lending, and illegal transactions are common. Balance sheet weaknesses have also contributed to the large spread between deposit and lending rates, averaging about 20-25 percent. Weaknesses in the legal system and corporate governance further explain the high spread (see Box 2).

- The environment is a high-risk one. Banks' reluctance to supply loans to the real economy reflects the unstable macroeconomic environment, inefficiencies in the judicial system, and shortcomings in corporate governance practices (see Box 2). Governance problems explain in part the high volume of cash transactions and the limited use of credit cards, leasing arrangements, and supplier's credits.

- The central bank lacks autonomy and accountability. Except in 2004, monetary objectives have not been met owing to insufficient operational autonomy of the central bank and fiscal dominance.

- Shortcomings in the conduct of monetary policy have also undermined the development of the financial system. The extensive reliance on reserve requirements and the high liquid asset ratio (at 40 percent) serves as a tax on financial intermediation and has hampered money market development. 
Figure 4. Nigeria: Financial Depth

Broad Money (In percent of GDP), 2000-2004
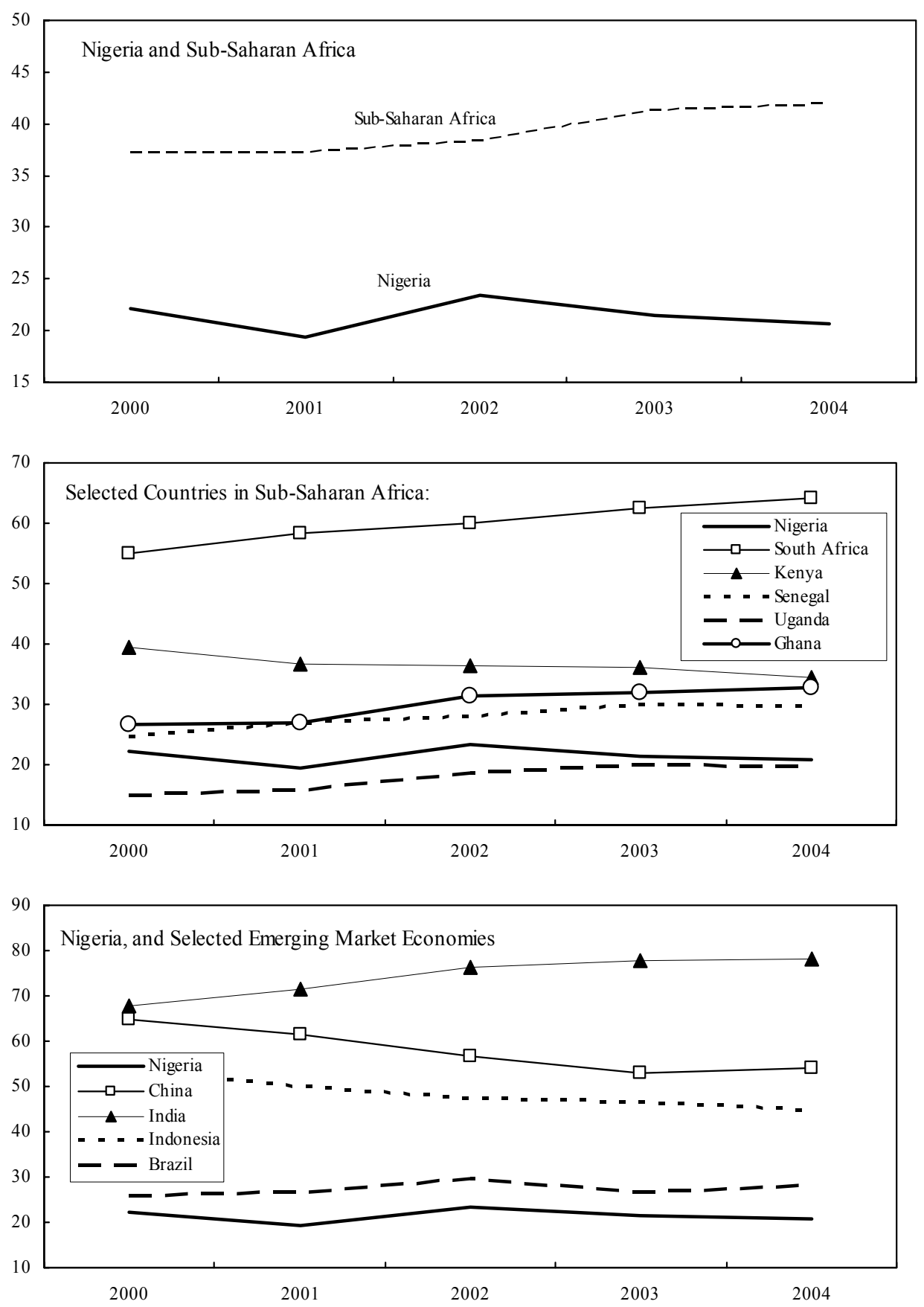

Source: IFS, and staff estimates. 
87. The 2002 FSAP also found shortcomings in the prudential and supervisory framework governing the banking system, in particular with regard to enforcement of regulations, consolidated banking supervision, and the supervision of the nonbanking system. In a number of areas, prudential regulations governing insider lending, including to shareholders, large exposure limits, loan classification, and provisioning were found to be inconsistent with international best practices.

88. The authorities, recognizing the importance of a sound and well-developed financial system for achieving the growth and poverty goals of the NEEDS, have launched a major reform to strengthen the banking system (see Box 3). More, however, will need to be done to spur financial intermediation. To encourage financial intermediation in a high-risk environment, several countries have reformed their collateral registry system to allow other pledges, such as receivables, firms' equipment or shares, and other movable property, to be used as collateral and have established public credit registries and a private credit bureau. ${ }^{55}$ Furthermore, corporate governance standards need to be strengthened in Nigeria. The national accounting, auditing, and reporting standards need to be brought in line with international best practices. Steeper penalties should be applied for misreporting and noncompliance. Standards governing small- and medium-sized enterprises (SMEs) should be strengthened and state-owned enterprises should comply with international accounting standards.

\footnotetext{
${ }^{55}$ Credit registries are information-sharing institutions that make credit information on borrowers available to lenders. Studies find that in low-income countries public credit registries play a constructive role, and, where they have been introduced, credit to SMEs and households has expanded. See Djankov, McLeish, and Shleifer (2005).
} 


\section{Box 2. Nigeria: Corporate Governance Practices}

Sound corporate governance practices are essential building blocks for fostering a good investment climate. They help creditors and investors make informed decisions, help build confidence in the company, and reduce capital costs.

Corporate governance practices have been weak in Nigeria. Nigeria's company law, Companies and Allied Matters Act, Bank and Other Financial Institutions Act, and the Securities and Exchange Commission's listing requirements incorporate many sound corporate governance features. However, past banking and corporate failures point to major weaknesses in corporate governance. Key problems are inadequate enforcement of statutory standards and a lack of sanctions for wrongdoing.

The 2002 FSAP and the World Bank's 2004 Report on the Observance of Standards and Codes (ROSC) on accounting and auditing also found serious shortcomings in regulations, compliance, and enforcement of current national standards and rules. Their main findings were as follows:

- $\quad$ The SASs are not in line with current International Accounting Standards (IAS). The ROSC indicates that are 14 international standards where there are no equivalent local standards. For instance, SAS does not provide standards for financial statement preparation and presentation, impaired assets, related party disclosure, consolidating group accounting, and companies in agriculture.

- $\quad$ Special financial reporting requirements for small companies are weaker than SASs and insufficient. In many cases, financial statements of nonlisted companies and private companies are not available.

- $\quad$ Although the Nigerian Accounting Standards Board (NASB), the standards-issuing body, has the mandate to monitor and enforce compliance with SAS, it lacks the financial and human resources and the capacity to do so, and SAS updates have been infrequent.

- A national auditing standard does not exist. Auditors are advised to follow International Standards on Auditing), but generally deviate significantly from best practices.

- There are significant compliance gaps with standards, including manipulation of accounts, misreporting, and failure to disclose relationships with related parties, including local and overseas suppliers.

- $\quad$ Pecuniary sanctions for violation of filing requirements either have not been imposed or have been minimal. As a result, they have not served as an effective deterrent for wrongdoing. This in part reflects the weak judicial system which has discouraged regulators and other stakeholders from action taking against companies in violation of statutory standards.

- $\quad$ Ethical codes governing the auditing body are not in line with international best practices. Auditors have limited skills and capacity to do in-depth reviews and often knowingly sign inaccurate reports. While audit committees exist, committee members typically do not perform their function.

- The 2001 on-site safeguard assessment also found notable shortcomings in audit and accounting practices within the CBN, such as the retention of one audit firm for over 25 years, no oversight of the external audit process, and noncompliance with SAS. 


\section{Box 3. Nigeria: Authorities' Financial Sector Reform Strategy}

- Increase the minimum capital base requirement to N25 billion at end-2005;

- $\quad$ Provide tax and other incentives to encourage banking consolidation; introduce a risk-focused and rules-based regulatory system;

- $\quad$ Improve banks' regulatory compliance and strengthen their corporate governance practices through adoption of a zero-tolerance policy;

- $\quad$ Develop an exit strategy for unsound banks;

- $\quad$ Strengthen supervision of the non-banking financial institutions, including insurances and community banks;

- $\quad$ Strengthen central bank autonomy and accountability;

- Improve corporate governance of banks and strengthen reporting requirements;

- Increase reliance on indirect instruments of monetary policy, thereby contributing to the development of the financial market;

- $\quad$ Remove the central bank as purchaser of government securities in the primary market and allow interest rates to clear the market;

- Unify the foreign exchange markets and lower burdensome foreign exchange regulations on banks.

\section{Conclusion}

89. The central challenge Nigeria faces is to create the broad-based conditions for rapid and sustained productivity growth in the private sector. Developments over the past 18 months and the development of NEEDS are evidence that Nigeria has turned the corner. NEEDS is appropriately focused on policies and reforms that will improve the investment climate and correct for past policy mistakes.

\section{Far-reaching reforms are needed for Nigeria to achieve higher sustainable} growth and attract foreign investment and technology. The growth experiences of China and India over the past decade or two can serve as an example for Nigeria. Their experiences show that higher per capita growth is attainable and that significant progress can be made in lowering poverty with appropriate policies and the right attitude. Both countries have liberalized their economies, opened them up to trade and foreign direct investment, and freed them from excessive government controls. They now rely primarily on private sector initiative to drive growth and innovation. The main challenge facing policymakers in Nigeria is to implement its reform agenda consistently over the medium term. 


\section{References}

Bleaney, M. Greenway D, 2002 "The Impact of Terms of Trade and Real Exchange Rate Volatility on Investment and Growth in Sub-Saharan African", Journal of Development Economics, 65(2): 491:500.

Djankov, Simeon D., La Porta, R. Lopez De Silanes, F., Shleifer, A., 2001, "The Regulation of Entry," World Bank Working Paper, No 2661. (Washington: World Bank).

Djankov, Simeon, McLiesh, C., Shleifer, A., 2005. "Private Credit in 129 Countries," NBER Working Paper No. 11078 http://www.nber.org/papers/w11078. Cambridge, MA

Morisset, Jacques and Neso, O., 2002 “Administrative Barriers to Foreign Investment in Developing Countries," Foreign Investment Advisory Service (Washington: World Bank), 2004.

Soenderbom, Mans, and Teal, F. (2002), "The Performance of Nigerian Manufacturing Firms: Report on the Nigerian Manufacturing Enterprise Survey 2001," Center for the Study of African Economies, University of Oxford August 2002.

Tahari, Amor, and Ghura, D., Akitoby. B., Brou, E., 2004, "Sources of Growth in SubSaharan Africa,'IMF Working Paper. WP/O4/ (Washington: International Monetary Fund)

Weiss, John, 1999. "Infrastructure and Economic Development," Economic Research Paper No. 50 African Development Bank 1999.

World Bank 2002, "An Assessment of the Private Sector in Nigeria," The World Bank Group September 2002 (Washington: World Bank). ,2003, “Nigeria Policy Options for Growth and Stability,” World Bank, Africa

Region, June 2003 (Washington: World Bank). , 2005, “Doing Business in 2005, World Bank, International Finance Corporation, and Oxford University Press (Washington: World Bank).

World Economic Forum, The African Competitiveness Report 2004, (Geneva, Switzerland: World Economic Forum). 


\section{Pension Reform in Nigeria 56}

\section{A. Introduction}

91. Nigeria launched a major reform of the pension system with the passage of the new Pensions Act in June 2004. This act seeks to establish a contributory, fully funded scheme for both the public and private sectors, based on individual accounts that will be privately managed by designated pension fund administrators, with pension funds assets held by pension assets custodians. It replaces a range of largely unregulated and highly diverse pension arrangements, including the pay-as-you-go pension systems for federal government employees; the partially funded, defined-benefit scheme administered by the Nigeria Social Insurance Trust Fund (NSITF) for workers in private sector firms with at least five employees; and, private firms' own funded pension schemes.

92. The goal of this paper is to analyze the Nigerian reform, its potential benefits, and its drawbacks. Toward that end, the paper will briefly review the literature on old-age security and other countries' experiences with similar reforms. With that framework, the paper will explore the rationale of Nigeria's pension reform, its implications, and the basic challenges ahead.

\section{B. Pension Reform: Issues and Country Experiences}

\section{The policy issue of old-age security has been receiving increased attention} worldwide as populations age and problems with existing schemes (including informal ones in less developed countries) surface. In recent decades, there has been a generalized drive to reform existing old-age security programs, including by replacing all or part of public (mainly defined-benefit) social security schemes with privately managed, definedcontribution systems based on individual accounts, in line with the 1994 study by the World Bank, Averting the Old-Age Crisis. That study identified three major objectives for old-age security systems (saving, redistribution, and insurance) and argued for differentiated government roles in light of evidence suggesting that multi-objective public schemes are problematic for both efficiency and distribution reasons (see below). It recommended a threepillar system: (i) a mandatory publicly managed pillar financed with taxes and with the unambiguous and limited function of alleviating old age poverty (redistribution objective) and coinsuring against multiple risks; (ii) a mandatory and fully funded privately managed pillar linking individual savings with pension benefits; and (iii) voluntary occupational or personal savings plans. While the redistribution and saving objectives would be dealt with separately, the insurance objective would be addressed in all three pillars.

\footnotetext{
${ }^{56}$ Prepared by Mauricio Villafuerte.
} 
94. The mandatory and fully funded, privately managed pension scheme should yield substantial benefits but requires a strong regulatory framework. Some benefits are directly associated with the drawbacks of publicly managed pay-as-you-go pension systems, a critical problem of which is that it does not clearly link contributions and benefits. That problem, combined with population dynamics, has frequently led to the promise of generous benefits that end up being financed with increasing taxes on labor and/or higher public sector debt. High labor taxes have led, in turn, to several distortions in labor markets, including lower employment, an expansion in the informal sector, increased tax evasion, and even strategic manipulations by workers to avoid costs but maximize pension benefits. In addition, the private sector should use more flexible and modern practices than the public sector in the management of pension funds. The second pillar would also have some benefits of its own, including increased transparency of fiscal liabilities, higher private capital accumulation and financial market development, and improved accountability (in fact, it should be more effective, in principle, to have the public sector rather than other public entities, regulate and supervise private operators). The 1994 World Bank study deemed a strong regulatory and supervisory framework a prerequisite for the second pillar to keep investment companies financially sound and to limit pension funds' exposure to risk.

Table 1. Some Major Pension Reforms (Defined-Contribution Systems)

\begin{tabular}{|c|c|c|c|c|}
\hline Country & Funded Pillar, Privately Managed & Safety Net & Status of Old System & Transition Mechanism \\
\hline Argentina (1994) & Optional second pillar & First pillar, flat pension & $\begin{array}{l}\text { Reformed, but open to new } \\
\text { workers }\end{array}$ & $\begin{array}{l}\text { Compensatory pension for previous years of } \\
\text { service }\end{array}$ \\
\hline Australia (1997) & Mandatory second pillar & Means-tested first pillar & Fully functional & Not needed; second pillar added to first \\
\hline Bolivia (1997) & Primary system & $\begin{array}{l}\text { Annual pension benefit for those at } \\
\text { least } 21 \text { years of age in } 1995 \text { out of } \\
\text { shares in state-owned firms }\end{array}$ & $\begin{array}{l}\text { Closed to new workers and } \\
\text { those below age } 35\end{array}$ & Compensatory pension \\
\hline Chile (1981) & Primary system & Minimum pension guarantee & Closed to new workers & $\begin{array}{l}\text { Recognition bonds payable at time of } \\
\text { retirement }\end{array}$ \\
\hline Hungary (1997) & Optional second pillar & Earnings-related first pillar & Closed to new entrants & Compensatory pension \\
\hline Kazakhstan (2000) & Primary system & Minimum pension guarantee & Closed completely & Compensatory pension \\
\hline Mexico (1995) & Primary system & Minimum pension guarantee & Closed completely & $\begin{array}{l}\text { Current workers retain rights to state pension } \\
\text { if higher }\end{array}$ \\
\hline Peru (1993) & Optional primary system & None & Open to new workers & Recognition bonds at time of retirement \\
\hline Poland (1999) & Mandatory second pillar & Notional accounts, first pillar & $\begin{array}{l}\text { Closed to new entrants and } \\
\text { workers under the age of } 30\end{array}$ & Notional initial capital \\
\hline Sweden (1994) & Mandatory second pillar & Notional accounts, first pillar & $\begin{array}{l}\text { Conventional defined = benefit } \\
\text { closed }\end{array}$ & $\begin{array}{l}\text { Compensatory pension in transition to } \\
\text { national accounts }\end{array}$ \\
\hline United Kingdom & Optional second pillar & Flat first pillar & Open to all & $\begin{array}{l}\text { Compensatory pension calculated based on } \\
\text { last contribution }\end{array}$ \\
\hline Uruguay (1995) & Optional second pillar & $\begin{array}{l}\text { Earnings-related first pillar, but with } \\
\text { ceiling }\end{array}$ & $\begin{array}{l}\text { Reformed, but open to new } \\
\text { workers }\end{array}$ & $\begin{array}{l}\text { Years of service recognized for those under } \\
40 \text {, but under new formula; older cohorts get } \\
\text { reformed benefits, phased in }\end{array}$ \\
\hline
\end{tabular}

Source: A. Schwarz and A. Demirguc-Kunt (1999).

95. Other countries' experiences with private fully funded pension schemes have, thus far, been relatively positive. ${ }^{57}$ Many Latin American countries, ${ }^{58}$ as well as some

\footnotetext{
${ }^{57}$ For detailed references see, for example, Schwarz and Demirguc (1999), Devesa-Carpio and Vidal (2002).

${ }^{58}$ In 1981, Chile introduced a fully funded, privately managed, defined-contribution scheme as the primary pension provider. Peru and Colombia (1993) decided to keep the pay-as-you-go definedbenefit scheme as the primary system. Argentina (1994) retained a pay-as-you-go defined-benefit
} 
transition economies, ${ }^{59}$ have transformed their pensions systems into funded systems under alternative arrangements. Preliminary evidence from the relatively young (with the exception of Chile) reforms suggests some generalized benefits in terms of financial sector deepening, higher gross returns on pension contributions, and higher participation rates (number of affiliates to the new systems). In Chile, the aggregate value of resources managed by pension funds rose from 1 percent of GDP in 1981 to 55 percent of GDP in 2001, the offer of financial instruments expanded substantially in size and variety, and there was evidence of increased "institutional capital" (a better legal framework, increased professionalism in the making of investment decisions, and increased transparency and integrity) in the capital markets following the pension reform (Walker and Lefort, 2002). The real average annual investment return surpassed 10 percent between 1981 and 2002, and replacement ratios were then estimated at 75-80 percent.

96. A few countries have sustained fiscal discipline, thereby, consolidating their achievement of long-term fiscal savings through the pension reform, which enables them to deal with the associated short-term and transitional costs. In addition, fiscal adjustment maximizes the impact of the pension reform on aggregate saving. In Chile, an explicit objective of the reform was to increase saving; hence, the government tightened up on other expenditure to achieve a fiscal surplus net of expenditure on social security. An added benefit of these reforms is that their implementation allowed governments to deflect the political problems associated with increasing taxes and cutting benefits under the old systems and to undertake more meaningful discussions about the sustainability of old-age security schemes.

\section{Despite their substantial benefits, the reforms implemented by the Latin} American countries and transition economies have had their share of problems. Some reforms failed mainly because short-term and transition costs were not addressed. For example, in Bolivia, which did not address the residual liabilities of the pay-as-you-go system or implement fiscal adjustment, the pension reform has increased the vulnerability of its public finances. ${ }^{60}$ More specific problems that have been identified are the failure to increase coverage ratios (measured as the ratio of active contributors to affiliates), the

scheme for the primary system, but introduced the option of a fully-funded defined-contribution scheme as a mandatory supplementary system. Uruguay (1995) retained the pay-as-you-go as the primary system, but made the fully funded defined-contribution scheme a mandatory second pillar for those of moderate income and optional, but subsidized, for those with low incomes. Mexico (1995) set up a system like the Chilean one, but with public and private fund management. El Salvador (1998), Bolivia (1997), and Costa Rica (2000) also carried out reforms.

${ }^{59}$ For example, Croatia, Estonia, Hungary, Kazakhstan, and Poland.

${ }^{60}$ Admittedly, some countries chose not to eliminate the old system as a way to reduce short-term and transition costs. However, the coexistence of old and new pension schemes creates problems, including political ones. In addition, the transition to a funded pillar never got off the ground in some countries, such as Nicaragua, because of the budgetary implications. 
persistence of high administrative charges from private operators, and limited diversification in the investment of pension funds. ${ }^{61}$ All those problems could translate into long-term fiscal costs through the activation of minimum pension guarantees and/or lower pension benefits and higher-old age poverty. In Chile and Peru, there have been intense debates about pension funds' insurance and management charges, which seem to be higher than the charges of other financial instruments and those of pension funds in other countries. Increased competition and regulatory flexibility have been proposed as efficient ways to reduce charges.

\section{Nigeria's 2004 Pension Reform Act: Implications and Challenges}

98. The pension system before the reform consisted of costly and poorly managed schemes for public workers and a centralized, partially funded, defined-benefit scheme supplemented by unregulated and unsupervised occupational (corporate funded) schemes for private sector workers.

\section{Previous pension system and the need for reform}

99. The noncontributory pay-as-you-go defined-benefit scheme for the public sector became increasingly costly and unsustainable. The fundamental problem with the old system was that benefits were very generous. Civil servants were eligible for a separation gratuity after 5 years of service and a pension after 10 years of service. At that point, the gratuity amounted to 100 percent of final salary, while the pension was 30 percent of salary, with each additional year of service increasing the gratuity by 8 percent and the pension benefit by 2 percent. After 35 years of service, a worker qualified for maximum benefitsthat is, a gratuity equal to 300 percent of final salary and a pension equal to 80 percent of final salary. In addition, benefits were adjusted after retirement by the Salary and Wages Commission to bring the benefits of existing pensioners in line with the benefits received by new retirees. Therefore, benefits were implicitly indexed to wages, because initial benefits were also linked to wages. The minimum retirement age was 50 (benefits were deferred until the age of 50 for those who left service earlier), with mandatory retirement at 60 years.

100. In addition, the public sector had a myriad of special schemes with more generous provisions. Terms were different - and more generous - for certain categories of workers, including military personnel, judges, and university professors. In fact, university professors could work until age 65 and qualify for a pension equal to 100 percent of their final salary. Military workers, on the other hand, could accrue benefits at the same rate as civil servants but were allowed to retire after only 10 years of service.

101. Because of the generous benefits, arrears accumulated as the public sector had difficulty paying current retirees their full benefits. Appropriations for pension benefits have fallen short of prescribed benefits during most of the recent years. A report by a special cabinet committee estimated that total arrears for federal retirement systems amounted to

${ }^{61}$ This is often the result of limits on investing abroad or high exposure to single parties (in particular the government). 
N85.5 billion as of May 2002 (Table 2), most of which was owed by federal parastatals. Those estimates have not been updated, but are thought to total between N100-200 billion (12 percent of Nigeria's 2004 GDP), not including arrears accumulated by state and local governments and their parastatals. As a result of the arrears, the old pension system was actually much less generous than it was designed to be.

Table 2. Nigeria: Federal Pension Liabilities, May 2002

(In billions of naira)

\begin{tabular}{lc}
\hline Retirement System & Accrued Arrears \\
\hline Civil service & 15.9 \\
Military & 0.0 \\
Police & 7.7 \\
Customs, immigration and prison services & 1.9 \\
Federal parastatals & 60.0 \\
Total & 85.5 \\
\hline
\end{tabular}

Source: IMF (2003).

102. Public pension schemes were plagued by administrative problems. The accumulation of arrears was also a manifestation of weak public expenditure management (as pension obligations were treated as mere expenditure items in the budget instead of as an insurable risk that required actuarial analysis and projections) and poor administration of the public pension schemes (the approval and payment of annuity benefits were subject to long lags). Part of the administrative problems derived from the absence of an integrated personnel and payroll system that allowed the creation of employment records.

103. Workers in the private sector were covered either by a centralized, partially funded scheme or by funded schemes set by their employers. The Nigeria Social Insurance Trust Fund (NSITF) managed a partially funded, defined-benefit scheme for workers in private sector establishments with at least five employees. ${ }^{62}$ Contributions to the NSITF were 10 percent of gross earnings ( 6.5 percent contributed by the employer), while the retirement pension rate for a worker who reached the age of 60 or more was 30 percent with 120 monthly contributions and 60 percent for 360 monthly contributions. In addition, some firms funded their own occupational pension schemes, including defined-benefit schemes. One problem with the private schemes was that they were largely unregulated and unsupervised. Therefore, no figures are available regarding their coverage and size.

\section{Main Features of the 2004 pension reforms act}

104. The Pensions Act passed in June 2004 establishes a new pension scheme that is contributory, fully funded, and based on privately managed individual accounts, with the

\footnotetext{
${ }^{62}$ It replaced the National Provident Fund, which was a savings scheme with meager monthly contributions and that was plagued by poor compliance by employers and inadequate benefit payments and one-off lump sum benefits to claimants.
} 
associated assets held by pension assets custodians. With the passage of the Pensions Act, Nigeria is at the forefront of low-income countries in the implementation of such a scheme.

105. Regarding coverage, the law makes it mandatory for employees of the public service of the Federation and the Federal Capital Territory, as well as for employees in private firms (with five or more employees), to join the contributory scheme when they begin working. Existing pensioners, judicial officers, and workers with three years or less before retirement are exempted from the scheme. Also, workers from state and local governments and associated parastatals are not affected by the new provisions.

106. Under this system, public sector employees' contributions are a minimum of 7.5 percent of their monthly emoluments (basic salary plus housing and transport allowances), but military personnel contribute 2.5 percent. Public entities have to contribute 7.5 percent, but 12.5 percent for the military. Employers and employees in the private sector contribute a minimum of 7.5 percent each of the employees' monthly emoluments.

Employers are obligated to deduct and remit contributions to a pension fund custodian (PFC) within seven days, and the PFC should, in turn, immediately notify a pension fund administrator (PFA) of its receipt of the contributions. Contributions and retirement benefits are tax-exempt.

107. Each employee opens an individual account with a PFA of his or her choice. This individual account belongs to the employee and remains with him or her through life: the employee may change employers or pension fund administrators (once a year, maximum), but the account remains the same.

108. Employees can withdraw funds from individual accounts only at the age of 50 or upon retirement thereafter. Lump sum withdrawals, however, would be allowed only when the amount remaining in the account is sufficient to set up programmed withdrawals or annuities of not less than 50 percent of an individual's monthly remuneration at the time of retirement. When an individual retires, he or she can use the balance after the lump sum payment to program monthly or quarterly withdrawals, to purchase an annuity for life through a licensed life insurance company with monthly or quarterly payments, or both.

109. The act specifically precludes taxing contributions and distributions.

110. According to the law, all employees (public and private) who have contributed for at least 20 years are entitled to a guaranteed minimum pension. The minimum pension amount will have to be specified by the government from time to time based on the recommendation of the National Pension Commission. The guaranteed minimum pension can be considered an explicit component of a first pillar of old-age security in Nigeria. However, the act does not specify who is responsible for the minimum pension.

111. In addition, the law mandates that employers maintain life insurance policies in favor of their employees for a minimum of three times their annual emoluments. This provision replaces survivor benefits for younger workers who do not accumulate a substantial retirement account.

112. A difficult issue linked to the transition to the new system has to do with the accrued pension rights of workers who shift to the new system. Public sector workers under the 
unfunded pay-as-you-go scheme will receive non-negotiable bonds redeemable upon retirement in an amount equivalent to the accrued benefits under the old scheme. In anticipation of the redemption of such bonds, the government has established the Retirement Benefits Bond Redemption Fund at the Central Bank of Nigeria and financed it with the equivalent of 5 percent of its total wage bill. ${ }^{63}$ In the case of the public sector's funded schemes and the private sector, employers have to credit the employees' individual savings accounts with any funds to which they are entitled; in the event of a deficiency, employers will have to issue a written obligation with repayment terms agreed on with the employee concerned.

113. Private schemes could continue to exist provided that they are fully funded, any shortfall is covered within 90 days, and the pension funds and assets are held by a PFC. Alternatively, the employer could also ask PENCOM to be licensed as a closed PFA. NSITF will establish a PFA that will also be regulated and supervised by PENCOM. Retirement savings accounts based on contributions to NSITF must remain with the PFA of NSITF for at least 5 years. Thereafter, each beneficiary will be free to determine which PFA will manage these funds on his or her behalf.

114. The National Pension Commission (PENCOM) is the entity charged with regulating and supervising of the pension schemes and has the power to formulate, direct, and oversee the overall policy on pension matters in Nigeria. PENCOM also has the mandate of ensuring the safety of the pension funds by issuing guidelines for licensing, approving, regulating, and monitoring the investment activities of pension funds' administrators and custodians. It comprises representatives from the government and labor, pensioners, and employers.

115. PFAs will have to be licensed by PENCOM to open retirement savings accounts for employees, decide on how pension funds should be invested in line with PENCOM's directives, maintain accounts on all transactions, provide regular information to the employees or beneficiaries, and pay retirement benefits to employees. PFAs must be limitedliability companies with the sole objective of managing the pension funds, with a paid-up share capital of N150 million, and with professional capacity to manage pension funds and administer retirement benefits. However, PFAs will not be allowed to hold the pension funds assets to safeguard the pension scheme. Rather, PFCs will have custody of pension fund assets and responsibility for executing transactions with instructions from the PFAs. PFCs must be limited-liability companies with a minimum capital of $\mathrm{N} 2$ billion (a shareholder bank must have a minimum net worth of N5 billion) to be granted an operating license. They are required to issue a guarantee for the full sum and value of the pension fund and assets they hold or will hold.

116. The investment of pension fund assets will be subject to specific guidelines from PENCOM and will include securities issued or guaranteed by the FGN and the CBN, securities and shares issued by listed corporations, bank deposits and securities, and foreign instruments (in line with the $\mathrm{CBN}$ is foreign exchange rules and with presidential approval).

${ }^{63}$ Without quantification, it is unclear if this contribution will be adequate. 
PFAs and PFCs will be allowed to deduct "clearly defined and reasonable fees, charges, costs and expenses" from the income earned from investing pension fund assets.

Table 3. Structure of Recently Reformed Pension Systems (Including Nigeria)

\begin{tabular}{|c|c|c|c|c|c|c|}
\hline & $\begin{array}{c}\text { Chile } \\
(1981)\end{array}$ & $\begin{array}{c}\text { Peru } \\
(1993)\end{array}$ & $\begin{array}{c}\text { Argentina } \\
(1994)\end{array}$ & $\begin{array}{c}\text { Mexico } \\
(1997)\end{array}$ & $\begin{array}{c}\text { Bolivia } \\
(1997)\end{array}$ & $\begin{array}{c}\text { Nigeria } \\
(2004) 1 /\end{array}$ \\
\hline Public PAYG system & Closed & Remains & Remains & Closed & Closed & Closed \\
\hline Affiliation of new workers & Mandatory & Voluntary & Voluntary & Mandatory & Mandatory & Mandatory \\
\hline $\begin{array}{c}\text { Contribution rate for savings } \\
\text { (percent of salary) }\end{array}$ & 10.0 & 8.0 & 7.7 & 12.1 & 10.0 & 15.0 \\
\hline $\begin{array}{c}\text { Commissions plus insurance } \\
\text { (percent of salary) }\end{array}$ & 2.3 & 3.7 & 3.3 & 4.5 & 2.5 & - \\
\hline Contribution collection & Decentralized & Decentralized & Centralized & Centralized & Decentralized & Decentralized \\
\hline Past contributions & Recognition bond & Recognition bond & $\begin{array}{c}\text { Compensatory } \\
\text { pension }\end{array}$ & $\begin{array}{c}\text { Previous resources/ } \\
\text { lifetime switch }\end{array}$ & $\begin{array}{c}\text { Compensatory } \\
\text { pension }\end{array}$ & Recognition bond \\
\hline Minimum pension & Yes & Yes & Yes & Yes & No & Yes \\
\hline Implicit pension debt 2/ & 100 & 37 & 86 & 42 & 48 & -- \\
\hline
\end{tabular}

Source: J. Devesa-Carpio and C. Vidal-Meliá (2002).

1/ Nigerian Pension Reform Act, 2004.

2/ In percent of GDP. Data from Brooks and James (1999).

\section{Implications of the reform}

117. The reform establishes a mandatory and fully funded privately managed pillar focused on old age savings. However, the new scheme allows for voluntary (and not taxed) contributions (the third pillar under the 1994 World Bank framework). There is no mandatory publicly managed pillar financed with taxes and with an explicit redistributive function, but there will be a minimum pension guarantee that is not yet clear how it will be financed. In addition, there is no coinsurance against a multitude of risks, but the new system provides for an employer-financed life insurance policy.

118. The reform improves the sustainability and reduces the vulnerability of the pension system for future pensioners. By fully funding the pension scheme, Nigeria reduces its vulnerability to adverse demographic trends and increases the probability that it will have the resources to pay benefits when workers retire. In addition, individual and privately managed retirement accounts with fully portable benefits should increase workers' confidence in the pension system.

\section{However, Nigeria has not dealt explicitly with the unsustainability of benefits} under the old PAYG system. The level of benefits for current pensioners, public sector employees within three years of qualifying for benefits, and even the accrued pension rights of current workers moving from the old to the new system are, in principle, protected by the pension reform legislation and cannot be adjusted even though they are recognized as being too generous. The inability to tackle this issue raises questions about equity and the transition costs of carrying two systems, as explained below.

120. The equity issue that arises has to do with the treatment of future public sector pensioners relative to current ones. In fact, the reform implies a reduced level of pension benefits for future public sector workers. Based on simulations undertaken by World Bank 
and IMF staff, the 15 percent contribution rate for federal government workers would result in a replacement rate at retirement (defined as the fraction of previous wages that initial pension benefits replace) for new workers of about 40 percent, compared with at least 80 percent for current pensioners. In addition, the new workers have to make part of the contributions into the new system. It could be argued that arrears and/or delays in distributing benefit payments to current pensioners reduce their effective replacement rate, but this asymmetry could lead to pressures to adjust future benefits (for example, through a higher minimum pension guarantee). However, the Pensions Act implies that these arrears will be satisfied in full, making the de facto benefits for current workers extremely generous.

121. The long-run fiscal savings from the reform will be limited if the benefits under the old pension system are not scaled down. In the short term, pension-related fiscal outlays will be substantially higher than under the previous scheme because the government will have to (i) deposit its contribution to the individual retirement accounts (equivalent to a fixed percentage of its wage bill), (ii) pay pensions to existing pensioners until they die, (iii) contribute an equivalent of 5 percent of the total wage bill to fund the future redemption of bonds issued in recognition of accrued pension rights under the old system for active workers migrating to the new system, and (iv) cover any shortfall to finance the actual redemption of such bonds as active workers retire. ${ }^{64}$ The last three items are referred to as transition costs and are basically linked to the level of benefits under the PAYG system. Over time, those outlays should fall, and the government's pension bill should be lower than under the previous PAYG system. In net present value terms, however, preliminary simulations done by World Bank and IMF staffs in 2003 suggested that the new system would cost only 10 percent less than the PAYG system if the benefits under the old pension system were not reduced. $^{65}$

\footnotetext{
${ }^{64}$ The 2005 federal government budget includes an allocation of N125 billion for pension-related with outlays, compared N70 billion in 2004.

${ }^{65}$ International experience shows the importance of carefully planning how to address the transition costs of the pension reform. For example, in Bolivia, pension costs are placing a high and increasing pressure on the budget because no provisions were made to address the residual liabilities of the PAYG system or to adjust in other spending or revenue items.
} 
Table 4: Simulation of Long-term Fiscal Costs

\begin{tabular}{lll}
\hline Benefit Arrangements & $\begin{array}{l}\text { Calculation of Total } \\
\text { Liabilities }\end{array}$ & $\begin{array}{l}\text { Ratio of Long-Run } \\
\text { Financing Costs } \\
\text { relative to 1979 Law }\end{array}$ \\
\hline $\begin{array}{l}\text { Pension according to the } \\
\text { benefit table specified in the } \\
\text { pension law of 1979 }\end{array}$ & $\begin{array}{l}\text { Present value of } \\
\text { expenditures over the } \\
\text { simulation horizon }\end{array}$ & 1.00 \\
\hline $\begin{array}{l}\text { Pension from individual } \\
\text { account with past non- } \\
\text { contributory service } \\
\text { compensated through }\end{array}$ & $\begin{array}{l}\text { Present value of } \\
\text { contributions }+ \text { present } \\
\text { recognition bonds }\end{array}$ & $\begin{array}{l}\text { value of recognition bonds } \\
+ \text { present value of pensions } \\
\text { to non switchers }\end{array}$ \\
&
\end{tabular}

Source: WB and IMF, 2003.

122. The minimum pension guarantee could create a substantial contingent liability for the government. The amount of this guarantee (for both public and private workers) still has to be determined by PENCOM. However, even if the objective of reducing old-age poverty is justified, the proper design of a guarantee is complicated by some difficult choices. First, its redistributive impact will depend on the coverage of the fully funded pension system, with the chance that mostly urban, formal, and relatively higher-income segments of the labor market benefit from such a policy. Second, it would be hard to define consistent thresholds for different segments of the labor market. Third, for those workers whose calculated pension is not close to the minimum pension, the guarantee would provide an incentive to retire as early as possible after accruing 20 years of service. In addition, if benefits for current beneficiaries are not revised, political pressures could build up to guarantee comparable benefits under the new pension system.

\section{The reform could increase the rate of saving in the economy and lead to a} deepening of capital markets. The national saving rate will increase as long as the increase in saving in funded retirement accounts is not offset by reductions in other forms of public or private saving. Two facts increase the probability that other forms of saving will not decline: much of the new saving will be done by low- to middle-income workers, who probably have relatively few financial savings, and public sector workers are not contributing to the old pension system. Regarding public savings, the sharp increase in oil revenue that is taking place at the same time as the pension reform is projected to boost the savings rate despite sizable increases in spending.

\section{Remaining challenges and the authorities' agenda}

\section{One critical challenge facing Nigeria ahead is the development of a} comprehensive regulatory and institutional framework. The Pension Act provides a general framework but not the detailed laws and regulations that will still need to be prepared. In addition, PENCOM's regulatory and administrative capacity need to be further 
developed. These will be difficult tasks, given capacity and governance constraints in Nigeria.

125. PENCOM is undertaking several activities in this area, concentrating on (i) the establishment of a regulatory and supervisory framework, including rules and regulations that govern the creation of custodian and investment management institutions that can hold and manage pension assets without exposing members to the risk of poor returns or losses of principal; (ii) the establishment of its own institutional structure and the recruitment and training of staff and management; (iii) the development of an IT strategy and acquisition of core software applications for surveillance and analysis; (iv) full-scale audit, reconciliation, and actuarial valuation of pension entitlements for federal government employees and retirees, and (v) the development of a strategy to reduce benefit arrears.

\section{Conclusions}

126. Nigeria decided to tackle the unsustainability of the pay-as-you-go scheme for public employees and the diversity of pension schemes for private workers by introducing a uniform, contributory, fully funded, and privately managed pension scheme. The pension reform, as currently designed, creates substantial short-term fiscal costs, and, apparently, limited savings in long-term fiscal costs. It also implies a sizable reduction in benefits for future pensioners relative to current beneficiaries. These problems suggest that there are strong equity and fiscal reasons for reducing both statutory benefits for current pensioners and documented liabilities for workers shifting from the old to the new system. At the same time, however, the lowest-income beneficiaries should be protected through the implementation of progressive cuts in statutory benefits.

\section{The reform's potential benefits in terms of improved management of pension} funds and financial deepening will depend critically on the establishment of adequate technological, institutional, and regulatory frameworks. They should help monitor the activities of private operators and ensure that future pensioners participate actively in saving for their old age. The authorities' agenda in these areas in coming months is ambitious and would benefit from the support of the World Bank, which has substantial expertise in this area. 


\section{References}

De Ferranti, D., et. al., 2002, “The Future of Pension Reform in Latin America”, Finance and Development

International Monetary Fund, 2003, "Nigeria. Pension Reform: Issues and Options", (unpublished and confidential)

Devesa, J. E., and C. Vidal-Melia, 2002, "The Reformed Pension Systems in Latin America", Social Protection Discussion Paper No. 0209, The World Bank

Gillingham R. and Kanda, 2001, "Pension Reform in India”, WP/01/125, IMF

Mackenzie, et.al., 1997, "Pension Regimes and Saving”, Occasional Paper No.153, International Monetary Fund

Schwarz, A. M. and A. Demirguc-Kunt, 1999, "Taking Stock of Pension Reforms around the World”, Social Protection Discussion Paper No. 9917, The World Bank

Walker, E. and F. Lefort, 2002, "Pension reform and capital markets: are there any (hard) links?", World Bank

World Bank, 1994, "Averting the Old-Age Crisis: Policies to Protect the Old and Promote Growth”, World Bank Policy Research Report, Oxford University Press

World Bank and International Monetary Fund, 2003, "Nigeria: Analysis of the Government's Pension Reform Proposal" (unpublished and confidential) 


\section{Nigerian Trade Policy ${ }^{66}$}

\section{A. Introduction}

128. This chapter provides an overview of trade policies in Nigeria, with a particular focus on changes in the policies since the staff's last survey in $2002 .{ }^{67}$ In recent years, Nigeria has made little progress in liberalizing trade, and its trade policy regime is one of the most restrictive in the world. The trade regime's strong anti-export bias is partially offset by a plethora of export promotion incentives. Although little is known about the specific effects of these incentives, the low level of non-oil exports suggests that they are largely ineffective. ${ }^{68}$

129. Nigeria's homegrown strategy, NEEDS, adopted in 2004, recognizes the shortcomings of the current trade policy framework. Consistent with the trade policy reforms elaborated in NEEDS, the government is in the process of significantly lowering import barriers, initiatives the staff supports. The section concludes with suggestions as to how the trade reforms can be broadened and deepened.

\section{B. Trade Policy Framework}

130. Nigeria pursues an active trade policy agenda. Its import trade protection regime is characterized by high levels of protection in the form of both tariffs and import bans. On the export side, a wide range of specific policy measures are designed to promote non-oil exports. Nigeria's multilateral and regional trade policies are framed by its membership in the World Trade Organization (WTO) and Economic Community of West African States (ECOWAS), respectively. Oil exports are also influenced by Nigeria's membership in OPEC.

\section{Import tariffs}

131. Currently, the (unweighted) average level of tariffs is exceptionally high at almost 30 percent. ${ }^{69}$ Indeed, of the 181 Fund member countries for which information was available in 2004, only 5 countries - The Bahamas, Comoros, Nigeria, Tonga, and Tunisia-

\footnotetext{
${ }^{66}$ Prepared by Lynge Nielsen.

${ }^{67}$ Trade and Openness Policies in Nigeria, Selected Issues Paper, Country Report 03/50, IMF.

${ }^{68}$ The low level of non-oil/gas exports also suggests that Nigeria has not benefited appreciably from the plethora of preferential market access schemes provided by industrial countries.

${ }^{69}$ In addition, importers are charged a port development levy of 7 percent of duty payable (equivalent to 2 percent of the simple average tariff), a comprehensive import supervision scheme charge of 1 percent (for preshipment inspection), and an ECOWAS community levy of 0.5 percent. Product-specific levies a 2 percent tax on vehicles and parts, a 10 percent tax on sugar, and a 10 percent levy on rice imports.
} 
had average tariffs (including other duties and charges) of 30 percent or higher. Nigeria's tariff schedule has 19 bands, ranging from 2.5 percent to 150 percent, with a modal rate of 15 percent. Despite the many bands, tariff dispersion is relatively moderate; for instance, for about one-fourth of all tariff lines, the tariff is set at the modal rate. Other positive features of the Nigerian tariff system, which ensure a given level of protection at lower costs to the economy, are that all tariffs are ad valorem and that no tariff-quotas are used.

\section{Protection of agriculture is particularly high, with average applied tariffs of} about 50 percent, twice the level of protection of other sectors. The last major tariff revision took place in March 2003, but had little effect on the overall level of protection. Average unweighted duty rates fell marginally, but the effective level of protection did not fall concomitantly, and the spread between duties on finished goods and duties on raw materials widened. Duties were cut on raw materials, base metals, and capital equipment and raised on various intermediate and final products, such as plastics and aluminum articles. Tariffs on corn, rice, and other agricultural products were also increased. In late 2004, minor amendments to the tariff schedule were introduced: they involved increasing the tariff rates on various packing materials from a range of 5-25 percent to a uniform rate of 60 percent and increasing the tariff rates on various types of natural starches from a range of 15-45 percent to a uniform rate of 75 percent.

\section{All agricultural tariff lines and 7 percent of other tariff lines are bound,} resulting in the binding of about 20 percent of all tariff lines. The average bound rate of 118 percent reflects relatively higher bindings on agricultural products. The large share of tariff lines without bindings and the large spread between bound and applied tariff rates do not make for a tariff system in which economic agents can have confidence that current actual tariffs rates will not increase. This, in turn, may affect private investment decisions negatively. 
$-60-$

Table 1. Nigeria: Import Prohibitions as of November 2004

Product Harmonized System Code

Effective as of September 2003

Wheat flour

Sorghum

Mosquito repellent coils

1001.0000

1007.0000

3808.1000

Rethreaded/used tires

4012.1000-4012.9000

8701-8705

Motor vehicles $^{\mathrm{a}}$

Gaming machines

Cement in bags

Vegetable oil in bulk

9504.1000-9504.3000

Used refrigerators

Used air-conditioners

2523.2910

1507.1100-1516.2000

8418.2100

8415.1000

Used compressors

Printed fabrics ${ }^{\mathrm{b}}$

Frozen poultry and poultry products

8414.8000 and 8415.3000

Chapters 52-55

0207.0000-0207.3600

Cassava and cassava products ${ }^{\mathrm{c}}$

$0714.1000,1106.2000,1108.1400$ and 1903.000

Toothpicks

Bottled water (sparking and non-sparking)

Biscuits

Noodles (including spaghetti)

Fruit juice in retail packs ${ }^{\mathrm{d}}$

Barite, bentonite, and attapulgite

Sugar confectioneries (sweets and chocolate)

Exercise books

Envelopes

Beer (bottled and canned)

Toilet rolls

Introduced in January 2004

Textiles, excluding the following

Nylon tire cord

Multifilament nylon chafer fabric and tracing cloth

Mattress tickings

Narrow fabrics

Trimmings and linings

Made-up fishing nets

Mosquito netting materials

Gloves for industrial use

Canvas fabrics for manufacture of fan belts

Moulding cups

Elastic bands

Motifs

Textile fabrics and articles for technical use

Transmission or conveyor belts or belting of textile materials

Polypropylene primary backing material

Fibre rope

Mutilated rags

Sacks and bags

Men's footwear and bags of leather and plastic

Soaps and detergents

Furniture

Assembled bicycles (excluding CKD)

Flowers (plastic and fresh)

Fresh fruit

Cutlasses, axes, pickaxes, spades, and shovels

Wheelbarrows

Pork and pork products, beef and beef products, mutton, lamb, and goat meat

2201.0000-2202.0000

1905.3000

1902.1100-1902.4000

2009.1100-2009.9000

2508.1000 .11 and 2508.1000 .19

1704.1000-1704.9000 and 1806.1000-1806.9000

4820.2000

4817.1000

2203

4803

Chapters 50-63

5902.1000-5902.9000

$5111.2000,5112.2000$ and 5901.9000

5903.1000-5903.9000

5806.1000-5806.4000

$5909.000,6117.9000,5808.9000,6003.000,6307.9000$

5608.1100

5608.1900 and 5609.9000

6116.1000-6116.9900

5907.000-5908.0000

6212.9000

5604.9000

5810.1000-5810.9000

5911.1000-5911.9000

5910.9000

$5512.1100-5512.9900$

5607.1000-5607.9000

6310.1100

6305.1000-6305.2000

3926.2000, 6401.1000-6405.9000, 4202.1100-4202.9900

3401.1100-3402.9000

9401.1000-9401.9000 and 9403.1000-9406.0000

8712.0000

0603.1000-0603.9000 and 6702.1000-6702.9000

0801.1100-0814.0000

$8201.1000-8201.9000$

8716.8000

0210.1900, 1602.4900, 0202.2000, 1602.5000, 1602.9000, 0204.1000, 0204.2200, 0304.3000, 0204.4200, 0204.4300, 0210.7900, 0204.5000, $0208.9000,0210.9900$, and 1602.9000

Toothpaste

Pencils

Ballpoint pens

Plastic plates, knives, spoons, forks, cups, buckets, bowls, bins,

3306.1000

9609.1000-9609.9000

9608.1000

3924.9000

4808.1000 and $4819.1000-4819.6000$

0106.3100-0106.9000, 0208.9000, and 0210.9900

Live or dead birds

Source: WTO.

a. Above eight years old and excluding tractors, trucks, trailers/trailer heads, and buses. In addition, the importation of any vehicle through land borders is prohibited.

b. All other textiles must be imported through Apapa and Tin Can Island ports in 20ft containers in the following range: (i) other textiles (non-printed) 110,000-140,000 meters; (ii) brocade/damask 120,000-130,000 meters; (iii) and, lace/embroidery 70,00080,000 meters. A minimum import price of $\$ 0.40$ /meter shall apply to all textiles under HS Chapters $50-63$. The importation of all textiles through land borders is prohibited.

c. The importation of all cassava and cassava products through land borders is prohibited.

d. Fruit juice may be imported in concentrates or drums only.

e. Drugs and pharmaceutical raw materials may only be imported through Calabar and Apapa ports, and Lagos and Kano airports. 


\section{Import bans}

134. Nigeria has a long history of banning imports of a broad range of products. After heavy use of such bans in the 1980s and early 1990s, their importance waned in the mid1990 s, as protection began to take the form of tariffs, among other forms, in line with Nigeria's WTO commitments.

135. In recent years, the use of import bans has once again become more prevalent, with major expansions in the list of prohibited products taking place in 2001, 2003, and 2004. In January 2004, bans were introduced on most types of textiles, men's footwear, plastic and leather bags, soaps and detergents, furniture, bicycles, flowers (plastic and fresh), fresh fruit, wheelbarrows, various meat products, toothpaste, pencils, and corrugated boards and cartons. In late 2004, Nigeria banned imports of cocoa powder and cake in order to encourage the use of locally processed cocoa. To offset the potentially negative effects of higher input costs on downstream producers, the government also launched a publicity campaign to encourage the consumption of chocolate drinks, including in schools. In early 2005 bans on various pharmaceutical products were introduced, but the government decided concurrently to lift the import ban on used cars because it had proved to be ineffective. ${ }^{70}$

\section{Import bans have proved to be difficult to enforce and many banned products} are readily available in Nigeria. Exemptions are also provided on a case-by-case basis, and some import bans are partially lifted from time to time. ${ }^{71}$ For example, at times specific companies have been permitted to import fruit juices even though the importation of such juices is banned, and the import ban on wheat flour has been suspended on occasion in line with developments in local market conditions. A particular objective in the latter case has been to encourage the use of cassava flour. ${ }^{72}$

\section{Most import bans are introduced at the behest of local manufacturing interests} and serve defensive protectionist purposes. However, the prohibition on imports of barites and bentonites is officially maintained for balance of payments reasons. ${ }^{73}$ Nigeria has also notified the WTO that the import bans on wheat flour, sorghum, millet, and kaolin were put in place for safeguard reasons. Nigeria has not imposed any antidumping and countervailing duties since 1998, opting instead to use import bans pending the integration of the WTO Agreement on Safeguards into domestic legislation.

\footnotetext{
${ }^{70}$ The ban was introduced in 2001. At the same time, imports of all vehicles across land borders were prohibited.

${ }^{71}$ Exemptions require the written approval of the president.

${ }^{72}$ Nigeria is the world's largest cassava producer. Bread can be baked using a mixture of cassava and wheat flour, and the Ministry of Agriculture is encouraging local bread producers to use a flour mix containing 10 percent cassava.

${ }^{73}$ Nigeria notified the WTO in 1999 that the ban on barites and bentonites would be lifted in 2000 , but as of end-2004 the ban was still in effect.
} 
138. Import bans are also used to encourage the production of goods deemed to benefit economic development objectives. For instance, to ensure a larger domestic share of value added in the booming cellular phone industry, an import ban on recharge cards was to have gone into effect at the end of 2004; the deadline, however, was extended because local companies were not yet ready to commence production. The government is also encouraging rice production by strengthening agricultural extension services and improving the availability of fertilizer and new types of seeds. In support of these initiatives, the government has announced the introduction of an import ban on rice starting in January 2006.

139. Imports of various products are also banned owing to security, health, or morality concerns. Examples are weapons, textile materials containing hazardous chemicals, and secondhand clothing. Finally, there are certain restrictions on products that can be imported across land borders (for example, cement, and medicine), and minimum shipment volumes for others (for example, cement imports cannot be less than 10,000 tons, and textile products must be imported in 20 -foot containers containing not less than 130,000 meters of fabric).

\section{Other import barriers}

140. Among other import barriers are discriminatory government procurement policies, the use of the tax code and other legislation to promote domestic production, inappropriate customs clearance procedures, and heavy-handed administration of standards and certification policies. It is difficult to gauge the extent to which such barriers hamper trade, but the prominent discussion such practices garner in the local press as well as among trading partners suggests that informal trade barriers are a significant problem. Specific examples of trade barriers are the requirement that uniforms of public officers be sourced locally, value added tax (VAT) exemption for locally produced fertilizer, and tax incentives under the investment act for companies that use domestic sources. However significant such specific policies are in particular sectors, it is probably the informal and more intractable barriers that distort trade the most.

\section{Export-promotion policies}

141. A broad range of policies have been put in place to encourage exports, such as lowering the cost of production (either by cutting red tape, lowering tax liabilities, lowering the costs of inputs, and improving the availability of financing).

\section{The Nigerian Export Processing Zone Authority (NEPZA) was established in} 1992, and it created Five Zones. Having had little success in attracting companies, the NEPZA converted the export-processing zones into free trade zones in $2001 .^{74}$ Currently,

\footnotetext{
${ }^{74}$ The change from export-processing zones to free trade zones essentially consisted in abrogating the rule that companies located in the zone should export at least 75 percent of their production.
} 
only the zones in Calabar and Onne are operational. The companies located in the Calabar free trade zone mostly market their products locally, but also in part within the West African sub-region, whereas the Onne zone is being used mainly to facilitate the export of liquefied natural gas. Incentives include tax holidays and fewer restrictions on foreign ownerships. In 2004, 22 firms in Calabar employed some 2,000 workers, and in Onne about 100 firms employed some 7,000 workers. Exports from Calabar amounted to \$50 million in 2003. Some states have also established export-processing zones, but it is unclear whether these zones are operational.

\section{Companies registered with the Nigerian Export Promotion Council (NEPC)} may benefit from various export incentives. An export-expansion grant scheme entitles eligible firms to a 4 percent grant on their export receipts. The scheme was introduced in 2002, but suspended in mid-2004 owing to concerns about fraudulent claims by companies. With stricter safeguards and eligibility rules in place, the scheme was re-launched in January 2005. Other incentives are a duty-drawback scheme providing a 60 percent refund to qualified importers, an export-adjustment fund scheme compensating companies for the cost disadvantages of infrastructural deficiencies and other factors beyond the control of the companies, and an export development fund providing financial assistance to private sector export companies to cover part of their initial expenses related to export promotion.

\section{The manufactures-in-bond scheme allows for the duty-free import of raw} materials - whether prohibited or not - for the production of export goods by companies posting bonds to guarantee the payment of duties in case the exports do not materialize. The scheme has proved difficult to administer and is under review. In November 2004, the import ban on certain U.S. textile and yarn products was lifted to encourage their use in a special manufactures-in-bond scheme.

145. Although highly underused, the Nigerian Export-Import Bank offers commercial bank guarantees and direct lending to facilitate exports. The Foreign Input Facility provides normal commercial terms of three to five years (or longer) for the importation of machinery and raw materials used for generating exports, and the Industrial Export Stimulation Facility provides exporters of manufactured goods with credits to import capital equipment and packaging and raw materials.

146. Besides the granting of tax holidays to companies located in free trade zones, tax relief is also provided to manufacturers exporting at least 50 percent of their production. Another tax incentive is tax relief for commercial banks that lend to exporters (a tax exemption is granted on interest earned from loans for export activities). 


\section{Export bans and taxes}

147. Nigeria bans the exports of a few products in accordance with the provisions in Nigeria's Export Prohibition Act. Currently, the products that cannot be exported are raw hides and skin, timber (rough and sawn), scrap metals, unprocessed rubber latex and rubber lumps, rice, yams, corn, beans, artifacts, and antiquities. Whereas the bans on hides, timber, metals, and rubber serve the purpose of ensuring lower-cost inputs for the manufacturing industry, the bans on rice, corn, and other food items are imposed on food-security grounds.

148. Export taxes are permitted under the 1992 Export Amendment Decree, which prescribes that all raw materials and unprocessed commodities (mineral or agricultural) may be subject to export levies as determined by the Nigerian Export Promotion Council. Currently, a levy of $\$ 5$ per ton is imposed on cocoa exports and a levy of $\$ 3$ per ton on other raw materials.

\section{Trade Performance}

149. The current trade policy framework combines high general barriers to trade and a plethora of derogations granted thereto by administrative fiat. The high import barriers entail an antiexport bias to the economy that is partly mitigated by various export incentive schemes. Much like a tax system with high tax rates and a widespread use of tax credits, the Nigerian trade policy framework allows the government to guide productive activities in directions of its choosing.

150. Nigeria's trade policy framework is significantly more restrictive than that found in most other countries, and it has become increasingly restrictive in recent years. In its 2005 trade policy review, the WTO concluded that Nigeria's trade policy regime had become more protectionist since its 1998 trade policy review. Over that same period, an array of developed, developing, and transition countries have pursued significant trade liberalization policies.

151. That Nigeria's trade policies are not aligned with those found elsewhere is not in itself a problem, but it is an issue that the restrictive policy framework is associated with a very weak export performance. Nigeria - with more than 2 percent of the world's population - has a share of the world's exports of about $1 / 3$ of 1 percent, of which more than 90 percent is oil and gas exports (Table 2). Over the past decade, Nigeria's non-oil and gas exports on a per capita basis amounted to only 1 percent of the world's average - the fourthlowest share in the world. ${ }^{75}$ Over a decade in which the world economy became significantly more integrated, Nigeria's non-oil and gas exports remained stuck at about 3 percent of GDP (6 percent of non-oil and gas GDP).

\footnotetext{
${ }^{75}$ Total exports of goods and services less oil exports for countries classified as fuel exporters in World Economic Outlook (WEO). Among 178 countries for which data are available, only Burundi, Ethiopia, and Rwanda had lower non-oil exports than Nigeria.
} 


\begin{tabular}{|c|c|c|c|c|c|c|c|c|c|c|c|}
\hline & 1994 & 1995 & 1996 & 1997 & 1998 & 1999 & 2000 & 2001 & 2002 & 2003 & $\begin{array}{l}\text { Prel. } \\
2004 \\
\end{array}$ \\
\hline \multicolumn{12}{|c|}{ (In percent of world total) } \\
\hline Exports of goods and services & 0.2 & 0.2 & 0.2 & 0.2 & 0.2 & 0.2 & 0.3 & 0.3 & 0.2 & 0.3 & 0.3 \\
\hline Of which: Non-oil/gas sector & 0.02 & 0.02 & 0.03 & 0.03 & 0.02 & 0.02 & 0.02 & 0.02 & 0.02 & 0.02 & 0.02 \\
\hline Imports of goods and services & 0.2 & 0.2 & 0.2 & 0.2 & 0.2 & 0.2 & 0.2 & 0.2 & 0.2 & 0.3 & 0.2 \\
\hline Of which: Non-oil/gas sector & 0.1 & 0.1 & 0.1 & 0.1 & 0.1 & 0.1 & 0.1 & 0.1 & 0.1 & 0.1 & 0.1 \\
\hline FDI & 0.2 & 0.2 & 0.3 & 0.4 & 0.2 & 0.1 & 0.1 & 0.3 & 0.4 & 0.5 & 0.6 \\
\hline Of which: Non-oil/gas sector & 0.07 & 0.07 & 0.08 & 0.14 & 0.06 & 0.04 & 0.04 & 0.14 & 0.11 & 0.05 & 0.09 \\
\hline \multicolumn{12}{|l|}{ GDP } \\
\hline Nominal & 0.1 & 0.1 & 0.2 & 0.1 & 0.1 & 0.1 & 0.1 & 0.2 & 0.1 & 0.2 & 0.2 \\
\hline Purchasing power parity & 0.3 & 0.3 & 0.3 & 0.3 & 0.3 & 0.3 & 0.3 & 0.3 & 0.3 & 0.3 & 0.3 \\
\hline \multicolumn{12}{|c|}{ (In percent of world total on a per capita basis) } \\
\hline Exports of goods and services & 10 & 10 & 12 & 12 & 8 & 9 & 15 & 12 & 11 & 14 & 15 \\
\hline Of which: Non-oil/gas sector & 1 & 1 & 1 & 1 & 1 & 1 & 1 & 1 & 1 & 1 & 1 \\
\hline Imports of goods and services & 9 & 10 & 10 & 10 & 9 & 10 & 9 & 10 & 11 & 11 & 11 \\
\hline Of which: Non-oil/gas sector & 6 & 7 & 6 & 7 & 6 & 7 & 5 & 7 & 6 & 7 & 6 \\
\hline FDI & 12 & 10 & 16 & 18 & 9 & 5 & 4 & 12 & 16 & 23 & 28 \\
\hline Of which: Non-oil/gas sector & 4 & 4 & 4 & 7 & 3 & 2 & 2 & 7 & 5 & 2 & 4 \\
\hline \multicolumn{12}{|l|}{ GDP } \\
\hline Nominal & 6 & 6 & 8 & 6 & 5 & 6 & 7 & 7 & 6 & 7 & 8 \\
\hline Purchasing power parity & 14 & 14 & 14 & 14 & 13 & 13 & 13 & 13 & 12 & 13 & 14 \\
\hline \multirow{2}{*}{\multicolumn{12}{|c|}{ Memorandum items: }} \\
\hline & & & & & & & & & & & \\
\hline Trade balance 1/ & 2 & 1 & 8 & 8 & -5 & -2 & 21 & 9 & 0 & 9 & 17 \\
\hline Exports of goods and services & 34 & 34 & 36 & 47 & 33 & 37 & 54 & 43 & 41 & 50 & 55 \\
\hline Of which: Non-oil/gas sector & 3 & 4 & 4 & 5 & 5 & 4 & 3 & 3 & 4 & 3 & 3 \\
\hline Imports of goods and services & 32 & 33 & 28 & 39 & 38 & 40 & 33 & 34 & 41 & 41 & 37 \\
\hline Of which: Non-oil/gas sector & 22 & 23 & 18 & 26 & 24 & 28 & 20 & 23 & 25 & 24 & 21 \\
\hline Non-oil/gas trade balance 2/ & -30 & -31 & -26 & -35 & -27 & -36 & -33 & -36 & -35 & -38 & -36 \\
\hline Exports of goods and services & 6 & 7 & 7 & 8 & 7 & 6 & 7 & 6 & 6 & 6 & 6 \\
\hline Imports of goods and services & 36 & 38 & 33 & 43 & 34 & 42 & 39 & 41 & 41 & 44 & 42 \\
\hline World exports 3/ & 20 & 22 & 22 & 23 & 23 & 23 & 25 & 24 & 24 & 25 & 27 \\
\hline Developing countries' exports 3/ & 23 & 25 & 25 & 25 & 25 & 27 & 31 & 30 & 32 & 34 & 37 \\
\hline Sub-saharan African countries' exports 3/ & 28 & 29 & 30 & 30 & 28 & 29 & 35 & 33 & 32 & 33 & 35 \\
\hline Oil export price (\$/barrel) & 16 & 17 & 21 & 20 & 13 & 18 & 28 & 24 & 25 & 29 & 38 \\
\hline \multicolumn{12}{|l|}{$\begin{array}{l}\text { 1/ In percent of GDP. } \\
\text { 2/ In percent of non-oil/gas GDP. } \\
\text { 3/ Exports of goods and services in perc }\end{array}$} \\
\hline
\end{tabular}

152. Trade policies also influence the broader policy framework that determines private sector choices of when and how to consume, invest, save, and trade with the outside world. In that regard, it is worth noting that Nigeria's poor export performance is also associated with low levels of foreign direct investment and weak economic growth. Except for investment in the oil and gas sectors, foreign investors have been largely absent 
from Nigeria, and little progress has been made toward closing the income gap with other countries.

153. Nigeria's export performance is also relatively weaker than that of two other control groups: fuel exporters and ECOWAS member countries. Whereas growth in Nigerian exports of goods, other than gas and oil, and services over the past decade was broadly in line with the exports of other countries in these two groups, exports other than oil and gas relative to output remained significantly lower in Nigeria than in most other countries.

\section{Where To Go From Here?}

154. As noted in the introduction, the NEEDS takes into account that Nigeria's current trade policies are largely failing to achieve any reasonable objectives and makes a strong case for adopting significantly more liberal policies in support of the government's growth and poverty-reduction

objectives. The inefficiencies of pre-NEEDS trade policies are succinctly described as follows: "The old development models of import substitution industrialization and statism, in which government assumed the dominant role as producer and controller in the economy, created perverse incentives, inefficiencies, and wastes." ${ }^{, 76}$ In the NEEDS, trade policy reform is appropriately considered an integral component of broader structural policies aimed at improving the business environment. Furthermore, the NEEDS recognizes that, without

${ }^{76}$ Nigerian National Planning Commission, 2004, page 10. 
further trade reforms - in particular, a lowering of import tariffs - progress in regional economic integration will prove elusive. Although the NEEDS is short on the specifics of what a more rational trade policy should look like, it makes clear that such a policy framework will have to be more predictable than the existing one and provide a lower and more uniform level of protection.

\section{Tariff reform}

155. The first NEEDS-inspired trade reform is scheduled to go into effect on July 1, 2005. With this tariff reform, Nigeria will adopt the ECOWAS common external tariff (CET) (with tariff bands of $0,5,10$, and 20 percent). An additional temporary 50 percent tariff band will be applied to selected import-competing goods. The maximum rate will decrease from 150 percent to 50 percent, while the average unweighted tariff rate will fall from about 30 percent to less than 20 percent. $^{77}$ The next steps in the authorities' reform program are the elimination of all import bans by end-2006 and the elimination of the 50 percent tariff band by end-2007.

\section{Reduction of non-tariff barriers}

156. While the government goes a long way toward establishing a less distortionary trade policy framework, it could consider accelerating the timetable for eliminating the import bans and the 50 percent tariff ban. Both of these measures hamper the development of free trade within ECOWAS. Furthermore, the import bans may be inconsistent with Nigeria's commitments to the WTO and are a constant source of friction between Nigeria and its trading partners. In the period leading up to the abolition of import bans, it is also advisable not to introduce any new bans; in particular, one can question the purpose of introducing a ban on rice in January 2006 if all import bans are to be abolished by year-end.

\section{Export promotion policies}

157. The rationalization of the import-protection policies will promote exports, but Nigeria would be well served by also encouraging exports directly by abolishing all export taxes and bans. Recent efforts to strengthen prudential oversight in the administration of the export-expansion grant scheme is welcome, but a broader strategic review of all export incentive schemes may suggest additional ways to streamline and rationalize the incentive system. Insofar as a case can be made for maintaining any particular incentive scheme, efforts should be directed toward delivering more targeted and effective assistance in a manner that minimizes the risk for abuse. The tax and investment codes

${ }^{77}$ Given the dominant role of oil-related revenues, import duties are not a significant source of fiscal revenues; it only amounted to 6 percent of total revenues in 2004 . The negative revenue impact from the tariff reform is mitigated by an expected strong growth in recorded imports resulting partly from a lowering of unrecorded imports. 
should also be pruned of export incentives, and the Value-added Tax code should be amended to make exports zero-rated rather than exempted. Finally, consideration should be given to centralizing export-promotion policies at the federal level so as to prevent companies from shopping around from state to state for the highest possible subsidies and concessions.

\section{Regional cooperation}

\section{Stronger regional trade links are critical in establishing a competitive,} integrated, but also open West African economic space. The ECOWAS customs union project is an important part of fostering stronger trade links, and, given Nigeria's dominant position in ECOWAS, Nigerian leadership is essential for that project to succeed. With the recent implementation of tariff reforms in Guinea, all but three of ECOWAS' 15 member countries have now broadly adopted the tariff schedule included in the proposed CET. In the 12 CET countries complying with the common external tariff, average unweighted tariff rates are 15 percent (including other duties and charges), with Liberia's and Cape Verde's tariffs being slightly lower and Nigeria's tariffs being more than double this average (Table 3). With regard to fostering the internal ECOWAS market, a lack of implementation of agreed measures has been an issue in several countries, but Nigeria has lagged behind other countries in implementing ECOWAS' Trade Liberalization Program. ${ }^{78}$ Looking

\begin{tabular}{|lc|}
\hline Table 3. Average Tariffs in ECOWAS Countries, end-2004 1 \\
\hline Country & Percent \\
\hline Benin & 15 \\
Burkina Faso & 15 \\
Cape Verde & 11 \\
Côte d'Ivoire & 15 \\
Gambia, The & 14 \\
Ghana & 15 \\
Guinea & 16 \\
Guinea-Bissau & 15 \\
Liberia & 12 \\
Mali & 15 \\
Niger & 15 \\
Nigeria & 33 \\
Senegal & 15 \\
Sierra Leone & 15 \\
Togo & 15 \\
& \\
Unweighted average & 16 \\
\hline & \\
\hline & \\
\hline
\end{tabular}
forward, Nigeria needs to take on a more proactive role in assuring that the trade integration program remains on track. Otherwise, the establishment of a fully functioning customs union by January 2008 will be jeopardized.

\footnotetext{
78 The Trade Liberalization Programme was introduced in 1990 with the aim of gradually liberalizing intra-ECOWAS trade over 15 years. The program provides for duty- and quotafree intra-ECOWAS trade in unprocessed goods and traditional handicrafts, with industrial goods benefiting from tariff reductions. Implementation is behind schedule.
} 


\section{Multilateral cooperation}

159. In the Doha Round negotiations, Nigeria should seize the opportunity to commit to binding all tariffs and lowering bindings significantly to approximate applied levels, steps that would enhance the predictability of the tariff system. Consideration could also be given to coordinating offers on new tariff bindings with other ECOWAS countries so as to minimize differences in tariff bindings at the regional level.

\section{E. Conclusions}

160. Nigeria's current trade protection regime is in dire need of reform. Although its high barriers to import have had the predictable consequence of stifling exports other than gas and oil, it has done little to encourage the development of either the agriculture or manufacturing sectors. The current system's reliance on administrative fiat rather than legislation to implement policies makes the system more flexible and therefore more adaptable to changing circumstances; unfortunately, the same flexibility has made the system prone to abuse as special interest groups' clamor for more protection has tended to prevail over general interest groups' call for lower protection. Over time, rent-seeking activities have become entrenched and the system progressively more restrictive.

161. The authorities' intention to break with past practices in the trade policy area is welcome. The tariff reforms to be implemented on July 1, 2005, represent a significant first step toward a more rational trade protection regime, but other reforms should follow soon after. The cumulative benefits from opening up the trade system are not necessarily frontloaded, and, although the trade system is being liberalized, economic agents who are negatively affected will engage in end runs to roll back the reforms. Momentum is thus of the essence if the trade reforms are to succeed. 


\section{References}

Nigeria's Export Promotion Policy, Government of Nigeria: mimeograph.

Meeting Everyone's Needs: National Economic Empowerment and Development Strategy, Nigerian National Planning Commission, 2004.

Trade Policy Review of Nigeria, WTO Secretariat, (WT/TPR/S/147, 13 April 2005).

2005 Report on Foreign Trade Barriers. United States Trade Representative. 
Table 1. Nigeria: Revised Gross Domestic Product by Sector of Origin at Current Prices, 2000-04

\begin{tabular}{|c|c|c|c|c|c|}
\hline & 2000 & 2001 & 2002 & 2003 & 2004 \\
\hline & \multicolumn{4}{|c|}{ (In millions of naira) } & \\
\hline Primary sector & $3,384,186$ & $3,813,987$ & $3,795,695$ & $5,225,444$ & $\ldots$ \\
\hline Agricultural activities & $1,192,910$ & $1,584,312$ & $1,700,451$ & $1,940,587$ & $\ldots$ \\
\hline Agriculture & $1,000,069$ & $1,328,733$ & $1,411,048$ & $1,628,349$ & $\ldots$ \\
\hline Livestock & 116,393 & 153,453 & 175,838 & 189,247 & $\ldots$ \\
\hline Forestry & 22,437 & 27,463 & 29,111 & 31,146 & $\ldots$ \\
\hline Fishing & 54,010 & 74,664 & 84,454 & 91,845 & $\ldots$ \\
\hline Mining and quarrying & $2,191,276$ & $2,229,675$ & $2,095,245$ & $3,284,857$ & $\ldots$ \\
\hline Of which: crude petroleum and gas & $2,186,682$ & $2,223,671$ & $2,089,470$ & $3,278,767$ & $\ldots$ \\
\hline Secondary sector & 200,841 & 244,586 & 293,612 & 342,988 & $\ldots$ \\
\hline Manufacturing & 168,037 & 201,393 & 250,187 & 293,083 & $\ldots$ \\
\hline Utilities & 2,200 & 2,438 & 4,234 & 5,153 & $\ldots$ \\
\hline Building and construction & 30,604 & 40,755 & 39,191 & 44,753 & $\ldots$ \\
\hline Tertiary sector & 952,610 & $1,119,598$ & $1,364,858$ & $1,779,358$ & $\ldots$ \\
\hline Transport & 129,092 & 145,661 & 179,365 & 239,378 & $\ldots$ \\
\hline Communication & 1,638 & 2,114 & 3,027 & 3,637 & $\ldots$ \\
\hline Wholesale and retail trade & 527,485 & 642,860 & 772,721 & $1,041,209$ & $\ldots$ \\
\hline Hotel and restaurants & 6,455 & 7,252 & 8,291 & 9,719 & $\ldots$ \\
\hline Finance and insurance & 43,775 & 54,383 & 79,449 & 70,113 & $\ldots$ \\
\hline Real estate & 165,070 & 171,768 & 206,626 & 276,583 & $\ldots$ \\
\hline Other private services & 44,077 & 55,385 & 66,405 & 87,907 & $\ldots$ \\
\hline Government services & 35,017 & 40,176 & 48,974 & 50,812 & $\ldots$ \\
\hline Gross domestic product at factor cost & $4,537,637$ & $5,178,171$ & $5,454,165$ & $7,347,790$ & $9,376,155$ \\
\hline Oil & $2,186,682$ & $2,223,671$ & $2,089,470$ & $3,278,767$ & $4,521,655$ \\
\hline Non-oil & $2,350,955$ & $2,954,500$ & $3,364,696$ & $4,069,023$ & $4,854,500$ \\
\hline Total indirect taxes (net) & 140,663 & 163,392 & 180,643 & 187,625 & 201,570 \\
\hline Subsidies & $-1,906$ & $-2,500$ & $-2,500$ & $-2,500$ & $-2,686$ \\
\hline Gross domestic product at market prices & $4,676,394$ & $5,339,063$ & $5,632,308$ & $7,532,915$ & $9,575,040$ \\
\hline \multicolumn{6}{|l|}{ Memorandum items: } \\
\hline Oil GDP & 48.2 & 42.9 & 38.3 & 44.6 & 48.2 \\
\hline Non-oil GDP & 51.8 & 57.1 & 61.7 & 55.4 & 51.8 \\
\hline Agricultural activities & 26.4 & 30.7 & 31.3 & 26.5 & $\ldots$ \\
\hline Secondary & 4.4 & 4.7 & 5.4 & 4.7 & $\ldots$ \\
\hline Tertiary sectors & 21.0 & 21.6 & 25.0 & 24.2 & $\ldots$ \\
\hline
\end{tabular}

Sources: Federal Office of Statistics; National Planning Commission; and staff estimates. 
Table 2. Nigeria: Revised Gross Domestic Product by Sector of Origin at Constant 1990 Prices, 2000-04

(In millions of naira)

\begin{tabular}{|c|c|c|c|c|c|}
\hline & 2000 & 2001 & 2002 & 2003 & $\begin{array}{c}2004 \\
\text { Prel. }\end{array}$ \\
\hline Primary sector & 232,466 & 239,052 & 230,615 & 263,299 & $\ldots$ \\
\hline Agricultural activities & 117,110 & 121,605 & 126,763 & 131,977 & $\ldots$ \\
\hline Agriculture & 98,179 & 101,988 & 105,189 & 110,742 & $\ldots$ \\
\hline Livestock & 11,427 & 11,778 & 13,108 & 12,870 & $\ldots$ \\
\hline Forestry & 2,203 & 2,108 & 2,170 & 2,118 & $\ldots$ \\
\hline Fishing & 5,302 & 5,731 & 6,296 & 6,246 & $\ldots$ \\
\hline Mining and quarrying & 115,356 & 117,447 & 103,852 & 131,322 & $\ldots$ \\
\hline Of which: crude petroleum and gas & 114,507 & 116,130 & 102,627 & 129,870 & $\ldots$ \\
\hline Secondary sector & 21,963 & 23,484 & 25,791 & 27,305 & $\ldots$ \\
\hline Manufacturing & 18,375 & 19,337 & 21,977 & 23,332 & $\ldots$ \\
\hline Utilities & 241 & 234 & 372 & 410 & $\ldots$ \\
\hline Building and construction & 3,347 & 3,913 & 3,443 & 3,563 & $\ldots$ \\
\hline Tertiary sector & 81,594 & 84,546 & 95,567 & 96,681 & $\ldots$ \\
\hline Transport & 12,698 & 12,653 & 14,870 & 15,737 & $\ldots$ \\
\hline Communication & 161 & 184 & 251 & 239 & $\ldots$ \\
\hline Wholesale and retail trade & 39,777 & 43,133 & 46,478 & 48,154 & $\ldots$ \\
\hline Hotel and restaurants & 635 & 630 & 687 & 639 & $\ldots$ \\
\hline Finance and insurance & 4,306 & 4,724 & 6,586 & 4,609 & $\ldots$ \\
\hline Real estate & 16,237 & 14,921 & 17,130 & 18,183 & $\ldots$ \\
\hline Housing & 4,336 & 4,811 & 5,505 & 5,779 & $\ldots$ \\
\hline Community and other services & 0 & 0 & 0 & 0 & $\ldots$ \\
\hline Government services & 3,444 & 3,490 & 4,060 & 3,341 & $\ldots$ \\
\hline Gross domestic product at factor cost & 336,858 & 347,998 & 352,941 & 391,300 & 415,332 \\
\hline Oil & 114,507 & 116,130 & 102,627 & 129,870 & 134,470 \\
\hline Non-oil & 222,351 & 231,868 & 250,314 & 261,430 & 280,862 \\
\hline Total indirect taxes (net) & 9,800 & 9,380 & 9,994 & 10,438 & 10,438 \\
\hline Subsidies & 133 & 163 & 186 & 194 & 209 \\
\hline Gross domestic product at market prices & 346,525 & 357,216 & 362,749 & 401,544 & 425,561 \\
\hline
\end{tabular}

Sources: Federal Office of Statistics; National Planning Commission; and staff estimates. 
Table 3. Nigeria: Revised Gross Domestic Product by Expenditure Category at Current Prices, 2000-04

(In millions of naira)

\begin{tabular}{|c|c|c|c|c|c|}
\hline & 2000 & 2001 & 2002 & 2003 & $\begin{array}{r}2004 \\
\text { Prel. }\end{array}$ \\
\hline External balance & $1,031,950$ & 575,369 & $-48,571$ & 619,374 & $1,648,357$ \\
\hline Exports of goods and nonfactor services & $2,537,758$ & $2,310,724$ & $2,296,286$ & $3,746,500$ & $5,231,686$ \\
\hline Goods & $2,429,388$ & $2,194,359$ & $2,159,568$ & $3,566,046$ & $5,007,385$ \\
\hline Nonfactor services & 108,370 & 116,365 & 136,718 & 180,454 & 224,301 \\
\hline Imports of goods and nonfactor services & $1,505,808$ & $1,735,356$ & $2,344,857$ & $3,127,126$ & $3,583,329$ \\
\hline Goods & $1,011,614$ & $1,184,500$ & $1,665,788$ & $2,249,894$ & $2,568,561$ \\
\hline Nonfactor services & 494,194 & 550,856 & 679,069 & 877,232 & $1,014,768$ \\
\hline Domestic demand & $3,644,444$ & $4,763,694$ & $5,680,879$ & $6,913,540$ & $7,926,683$ \\
\hline Consumption & $2,696,889$ & $3,477,497$ & $4,203,851$ & $5,116,020$ & $5,786,478$ \\
\hline Government & 978,668 & $1,445,737$ & $1,364,903$ & $1,787,610$ & $2,117,953$ \\
\hline Private & $1,718,221$ & $2,031,760$ & $2,838,948$ & $3,328,410$ & $3,668,526$ \\
\hline $\begin{array}{l}\text { Gross investment } \\
\text { Stock changes }\end{array}$ & 947,555 & $1,286,198$ & $1,477,029$ & $1,797,521$ & $2,140,204$ \\
\hline Gross fixed investment & 947,555 & $1,286,198$ & $1,477,029$ & $1,797,521$ & $2,140,204$ \\
\hline Government fixed investment & 447,984 & 737,590 & 564,590 & 727,045 & 874,120 \\
\hline Private fixed investment & 499,572 & 548,607 & 912,439 & $1,070,476$ & $1,266,085$ \\
\hline Gross domestic product at market prices & $4,676,394$ & $5,339,063$ & $5,632,308$ & $7,532,915$ & $9,575,040$ \\
\hline Net factor income from abroad & $-644,978$ & $-476,732$ & $-782,164$ & $-1,097,634$ & $-1,574,475$ \\
\hline Gross national product at market prices & $4,031,416$ & $4,862,331$ & $4,850,144$ & $6,435,281$ & $8,000,566$ \\
\hline Net transfers from abroad & 160,339 & 143,074 & 170,897 & 273,033 & 369,374 \\
\hline National disposable income & $4,191,756$ & $5,005,405$ & $5,021,041$ & $6,708,314$ & $8,369,939$ \\
\hline National savings $1 /$ & $1,494,867$ & $1,527,908$ & 817,190 & $1,592,294$ & $2,583,461$ \\
\hline Gross domestic savings 2/ & $1,979,506$ & $1,861,566$ & $1,428,457$ & $2,416,895$ & $3,788,562$ \\
\hline
\end{tabular}

Sources: Federal Office of Statistics; National Planning Commission; and staff estimates.

1/ National disposable income less aggregate consumption.

2/ Domestic disposable income less aggregate consumption. 
Table 4. Nigeria: Revised Gross Domestic Product by Expenditure at Constant 1990 Prices, 2000-04 (In millions of naira)

\begin{tabular}{|c|c|c|c|c|c|}
\hline & 2000 & 2001 & 2002 & 2003 & $\begin{array}{c}2004 \\
\text { Prel. }\end{array}$ \\
\hline External balance & 150,755 & 125,189 & 58,978 & 120,733 & 127,073 \\
\hline Exports of goods and nonfactor services & 303,880 & 291,955 & 259,450 & 342,328 & 353,085 \\
\hline Goods & 290,903 & 277,253 & 244,003 & 325,839 & 337,947 \\
\hline Nonfactor services & 12,977 & 14,703 & 15,447 & 16,489 & 15,138 \\
\hline Imports of goods and nonfactor services & 153,125 & 166,766 & 200,473 & 221,595 & 226,013 \\
\hline Goods & 102,870 & 113,829 & 142,416 & 159,432 & 162,008 \\
\hline Nonfactor services & 50,254 & 52,937 & 58,057 & 62,163 & 64,005 \\
\hline Domestic demand & 195,770 & 232,027 & 303,771 & 280,811 & 298,489 \\
\hline Consumption & 152,701 & 180,981 & 224,791 & 207,800 & 217,897 \\
\hline Government & 79,907 & 100,009 & 83,054 & 95,398 & 98,272 \\
\hline Private & 72,794 & 80,972 & 141,736 & 112,402 & 119,625 \\
\hline Gross investment & 43,069 & 51,046 & 78,981 & 73,011 & 80,592 \\
\hline Stock changes & 2 & 0 & 0 & 0 & 0 \\
\hline Gross fixed investment & 43,069 & 51,046 & 78,981 & 73,011 & 80,592 \\
\hline Government & 19,577 & 23,203 & 30,377 & 28,081 & 29,849 \\
\hline Private & 23,492 & 27,843 & 36,453 & 33,697 & 35,819 \\
\hline Gross domestic product at market prices & 346,525 & 357,216 & 362,749 & 401,544 & 425,561 \\
\hline Net factor income from abroad & $-65,587$ & $-45,814$ & $-66,871$ & $-77,781$ & $-99,308$ \\
\hline Gross national product at market prices & 280,938 & 311,402 & 295,878 & 323,763 & 326,254 \\
\hline Net transfers from abroad & 16,305 & 13,749 & 14,611 & 19,348 & 23,298 \\
\hline National disposable income & 297,243 & 325,152 & 310,489 & 343,111 & 349,551 \\
\hline National savings 1 / & 144,542 & 144,171 & 85,698 & 135,311 & 131,655 \\
\hline Gross domestic savings $2 /$ & 193,824 & 176,235 & 137,958 & 193,744 & 207,664 \\
\hline
\end{tabular}

Sources: Federal Office of Statistics; National Planning Commission; and staff estimates.

1/ National disposable income less aggregate consumption.

2/ Domestic disposable income less aggeragate consumption. 
Table 5. Nigeria: Selected Petroleum Statistics, 2000-04

\begin{tabular}{|c|c|c|c|c|c|}
\hline & 2000 & 2001 & 2002 & 2003 & 2004 \\
\hline Production and exports & \multicolumn{5}{|c|}{ (Millions of barrels per day) } \\
\hline Production 1/ & 2.261 & 2.238 & 1.960 & 2.453 & 2.492 \\
\hline Domestic allocation & 0.302 & 0.389 & 0.447 & 0.431 & 0.418 \\
\hline Exports 2/ & 1.952 & $\begin{array}{r}1.849 \\
\text { (U.S. }\end{array}$ & $\begin{array}{l}1.513 \\
\text { ars per bar }\end{array}$ & 2.022 & 2.075 \\
\hline Average price of Nigerian crude & 28.00 & 24.48 & 25.05 & 29.02 & 38.28 \\
\hline U.K. Brent, average price $3 /$ & 28.31 & 24.41 & 25.00 & 28.85 & 38.28 \\
\hline Export values 2/ & 20,151 & 16,574 & 13,834 & 21,415 & 28,993 \\
\hline & \multicolumn{5}{|c|}{ (in Naira per liter, unless otherwise indicated) } \\
\hline Domestic petroleum product prices 4/ & & & & & \\
\hline Crude oil (naira per barrel) $5 /$ & 950.00 & 950.00 & 1980.00 & $2,487.00$ & $5,141.65$ \\
\hline Premium motor spirits & 22.00 & 22.00 & 26.00 & 31.50 & $\ldots$ \\
\hline Kerosene & 17.00 & 17.00 & 24.00 & 29.08 & $\ldots$ \\
\hline Gas oil/diesel & 21.00 & 21.00 & 26.00 & 31.50 & $\ldots$ \\
\hline Domestic consumption of petroleum products & \multicolumn{5}{|c|}{ (In thousands of metric tons) } \\
\hline Premium motor spirits & $4,799.6$ & $5,397.6$ & $6,928.9$ & $6,294.1$ & \\
\hline Kerosene & $1,217.0$ & $1,744.4$ & $1,281.9$ & 906.3 & \\
\hline Gas oil/diesel & $2,195.3$ & $2,179.2$ & $1,910.0$ & $1,886.1$ & \\
\hline Fuel oil (high and low “pour”) & $\ldots$ & 174.4 & 220.9 & $1,287.6$ & \\
\hline Liquefied petroleum gas & $\ldots$ & 13.8 & $\ldots$ & $\ldots$ & $\ldots$ \\
\hline Aviation spirits & $\ldots$ & $\ldots$ & $\ldots$ & $\ldots$ & $\ldots$ \\
\hline
\end{tabular}

Sources: Central Bank of Nigeria; Nigerian National Petroleum Corporation; and Fund staff estimates.

1/ Includes condensates.

2/ Balance of payments basis, including exports of condensate.

3/ U.K. Brent, light-blend 38 API, f.o.b. United Kingdom.

4/ For 2003, simple averages for the year.

5/ Price at which the NNPC buys government equity crude for domestic refining. 
Table 6. Nigeria: Selected Indicators of Agricultural Production and Prices, 2000-03

\begin{tabular}{|c|c|c|c|c|}
\hline & 2000 & 2001 & 2002 & 2003 \\
\hline \multicolumn{5}{|l|}{ Food crops } \\
\hline Millet & 6,765 & 7,088 & 7,231 & 7,377 \\
\hline Sorghum & 8,854 & 9,408 & 9,687 & 9,974 \\
\hline Maize & 6,491 & 6,592 & 6,698 & 6,806 \\
\hline Rice (paddy) & 3,865 & 3,989 & 4,085 & 4,183 \\
\hline Yams & 26,451 & 27,589 & 28,979 & 30,439 \\
\hline Cassava & 36,795 & 37,949 & 39,410 & 40,927 \\
\hline \multicolumn{5}{|l|}{ Export crops } \\
\hline Cocoa & 170 & 171 & 172 & 173 \\
\hline Groundnuts & 2,390 & 2,361 & 2,375 & 2,389 \\
\hline Palm kernels & 629 & 632 & 645 & 658 \\
\hline Cotton & 353 & 359 & 379 & 400 \\
\hline Sheanuts & 448 & 455 & 463 & 471 \\
\hline Rubber & 275 & 279 & 284 & 289 \\
\hline \multicolumn{5}{|c|}{ Average prices for food crops } \\
\hline Millet & 21,264 & 33,528 & $\ldots$ & $\ldots$ \\
\hline Sorghum & 19,284 & 34,945 & $\ldots$ & $\ldots$ \\
\hline Maize & 20,719 & 37,351 & $\ldots$ & $\ldots$ \\
\hline Rice & 46,997 & 51,003 & $\ldots$ & $\ldots$ \\
\hline Yams & 20,975 & 56,333 & $\ldots$ & $\ldots$ \\
\hline Cassava & 10,969 & 20,613 & $\ldots$ & ... \\
\hline \multicolumn{5}{|c|}{ Average prices for export crops } \\
\hline Cocoa & 90,000 & 100,744 & $\ldots$ & $\ldots$ \\
\hline Groundnuts & 44,110 & 44,843 & $\ldots$ & $\ldots$ \\
\hline Palm kernels & 21,260 & 23,379 & $\ldots$ & $\ldots$ \\
\hline Cotton & 35,000 & 33,204 & $\ldots$ & $\ldots$ \\
\hline Rubber & 59,400 & 69,800 & $\ldots$ & $\ldots$ \\
\hline
\end{tabular}

Sources: Federal Office of Statistics; Federal Ministry of Agriculture; and Central Bank of Nigeria. 
Table 7. Nigeria: Index of Industrial Production, 2000-03

\begin{tabular}{|c|c|c|c|c|}
\hline & 2000 & 2001 & 2002 & 2003 \\
\hline & \multicolumn{4}{|c|}{$(1985=100)$} \\
\hline Total industrial production & 134.6 & 145.3 & 145.2 & $\ldots$ \\
\hline Manufacturing & 136.9 & 146.3 & 146.3 & $\ldots$ \\
\hline Sugar confectionary & 56.8 & 47.5 & 52.8 & $\ldots$ \\
\hline Soft drinks & 164.8 & 194.0 & 208.3 & $\ldots$ \\
\hline Beer and stout & 120.6 & 125.7 & 128.3 & $\ldots$ \\
\hline Cotton textiles & 98.5 & 93.7 & 95.0 & $\ldots$ \\
\hline Synthetic fabrics & 717.3 & 665.6 & 718.1 & $\ldots$ \\
\hline Footwear & 46.1 & 44.9 & 46.2 & $\ldots$ \\
\hline Paints & 114.0 & 114.4 & 121.0 & $\ldots$ \\
\hline Refined petroleum & 114.0 & 133.0 & 133.9 & $\ldots$ \\
\hline Cement & 88.7 & 93.5 & 94.5 & $\ldots$ \\
\hline Roofing sheets & 30.9 & 27.6 & 30.4 & $\ldots$ \\
\hline Vehicle assembly & 13.7 & 15.0 & 17.6 & $\ldots$ \\
\hline Soap and detergent & 189.1 & 210.1 & 214.0 & $\ldots$ \\
\hline Radio and televisions & 3.9 & 3.3 & 3.8 & $\ldots$ \\
\hline Mineral production & 137.5 & 144.9 & 133.7 & $\ldots$ \\
\hline Petroleum & 138.8 & 146.3 & 134.9 & $\ldots$ \\
\hline Gas & 191.5 & 225.0 & 240.3 & $\ldots$ \\
\hline Cassiterite & 26.1 & 24.5 & 25.0 & $\ldots$ \\
\hline Columbite & 98.2 & 97.7 & 98.3 & $\ldots$ \\
\hline Coal & 10.8 & 11.3 & 11.4 & $\ldots$ \\
\hline Limestone & 5.9 & 6.4 & 6.5 & $\ldots$ \\
\hline \multirow[t]{2}{*}{ Electricity production } & 136.1 & 144.6 & 146.7 & $\ldots$ \\
\hline & \multicolumn{4}{|c|}{ (In thousands of megawatts) } \\
\hline Electricity consumption & 8,689 & 9,035 & 8,894 & $\ldots$ \\
\hline Industrial & 2,200 & 2,200 & 2,200 & $\ldots$ \\
\hline Commercial and street lighting & 2,083 & 2,083 & 2,083 & $\ldots$ \\
\hline Residential & 4,406 & 4,752 & 4,611 & $\ldots$ \\
\hline
\end{tabular}

Source: Central Bank of Nigeria. 


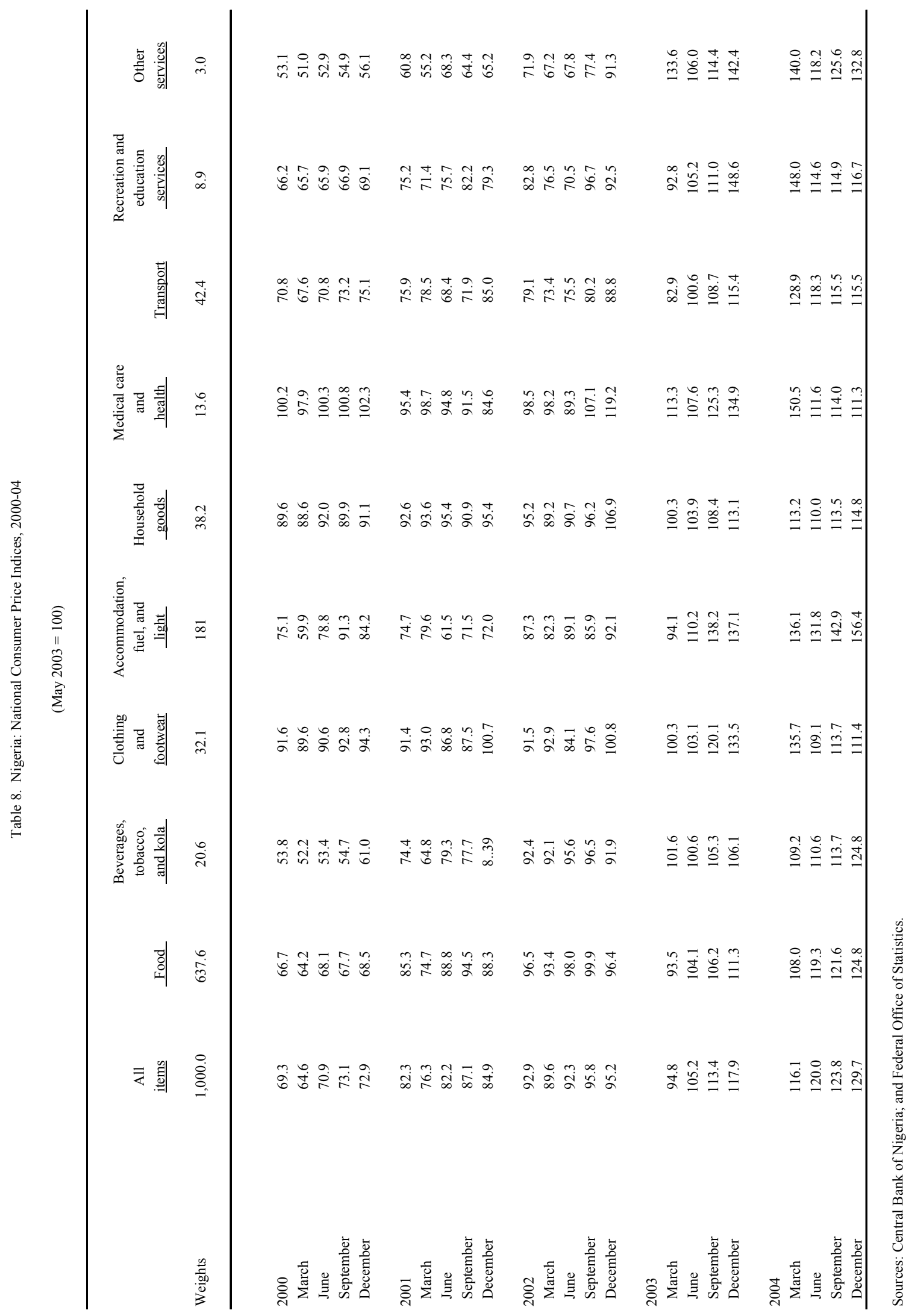




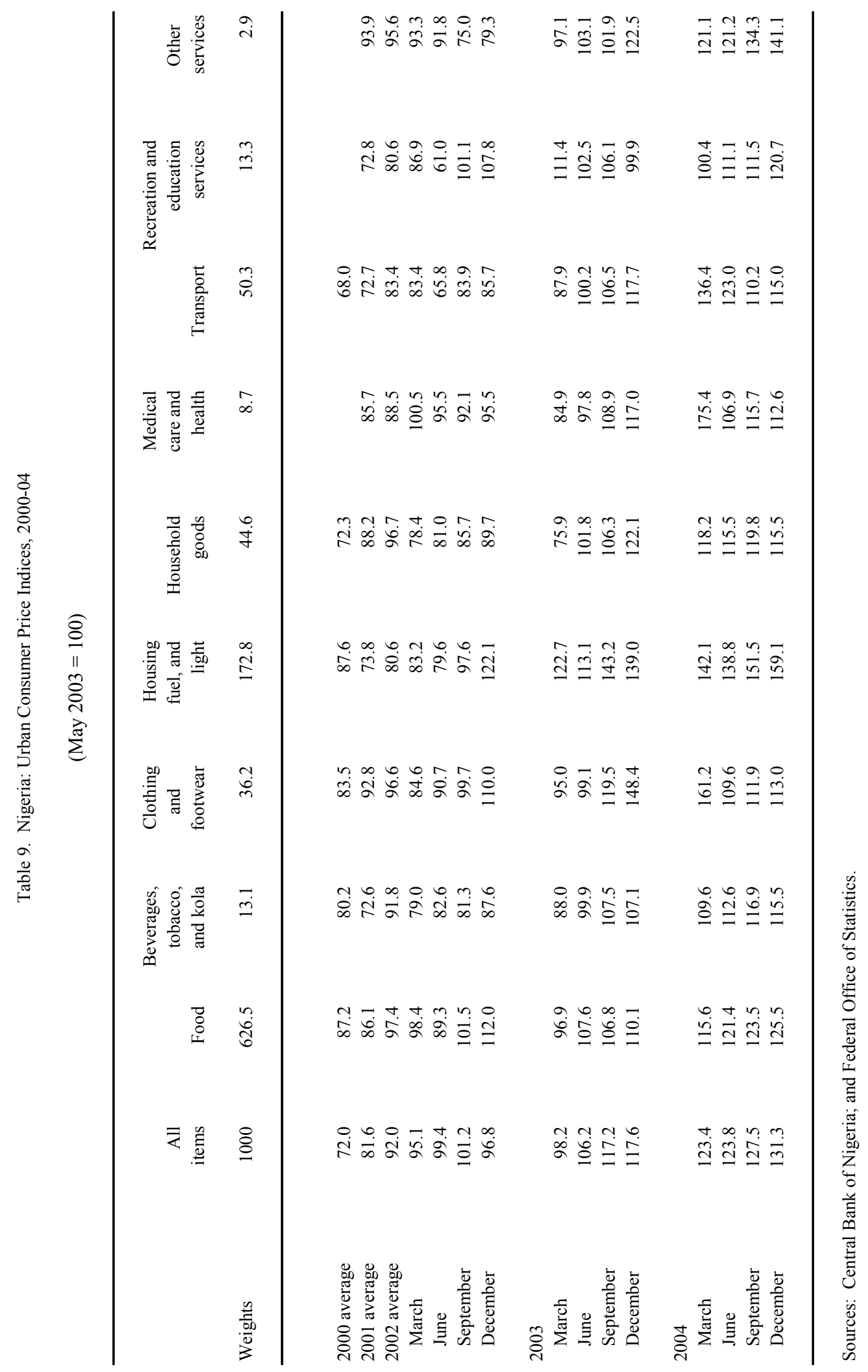




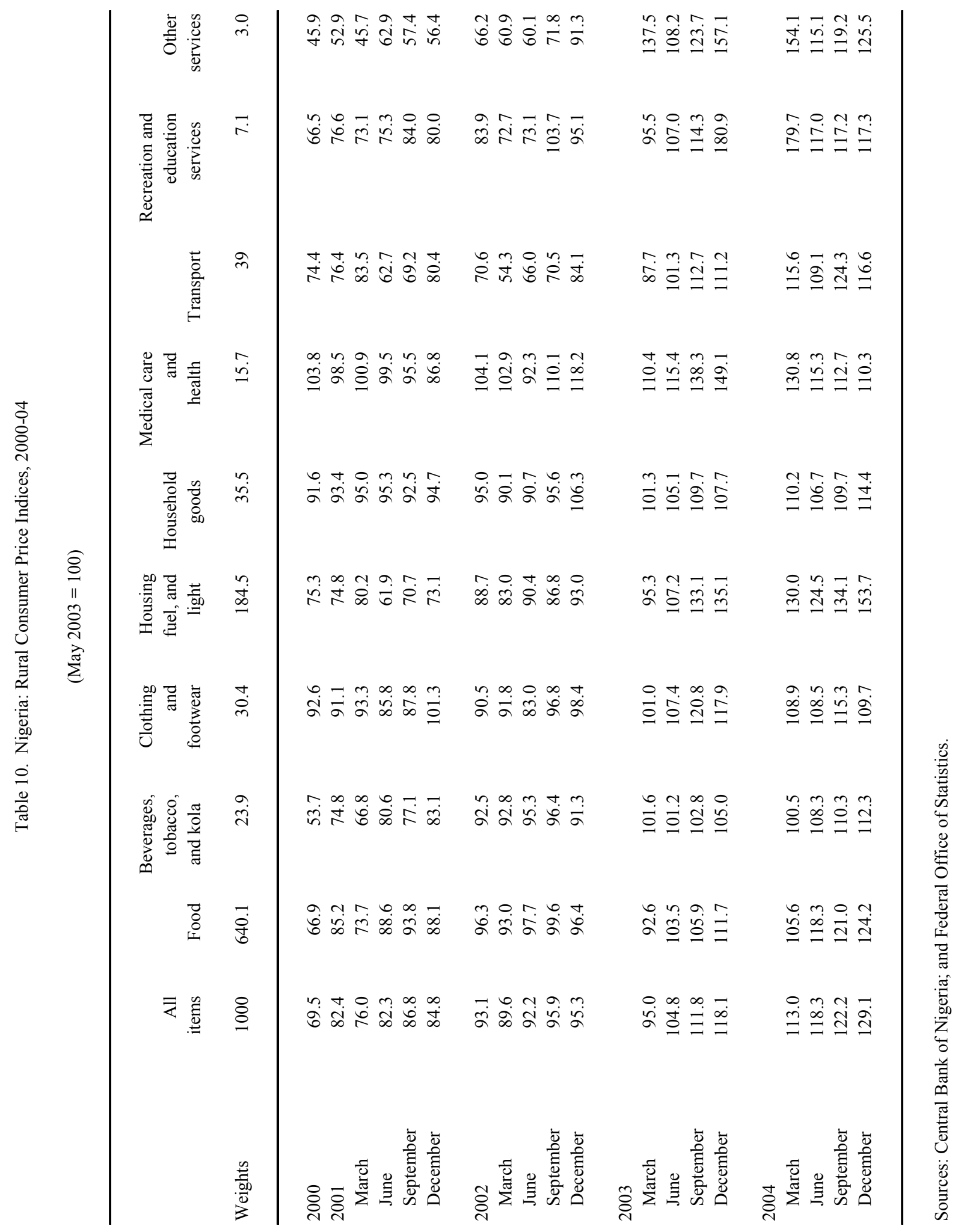


Table 11. Nigeria: Consolidated Government Revenue, 2000-04 1/

(in millions of naira)

\begin{tabular}{lrrrrr}
\hline & & & & & Prel. \\
& 2000 & 2001 & 2002 & 2003 & 2004 \\
\hline & & & & & \\
Total revenue & $1,986,949$ & $2,247,884$ & $2,052,825$ & $2,794,767$ & $4,123,586$ \\
& & & & & \\
Tax revenue & 636,082 & 876,376 & 732,710 & $1,072,559$ & $1,535,766$ \\
Taxes on net income, profits, and capital gains & 436,442 & 560,110 & 422,701 & 701,363 & $1,126,268$ \\
$\quad$ Petroleum profits tax & 332,542 & 405,941 & 223,999 & 437,964 & 825,843 \\
$\quad$ Company income tax 2/ & 51,147 & 68,726 & 89,104 & 114,770 & 130,129 \\
$\quad$ Education tax & 7,444 & 16,214 & 9,570 & 9,704 & 17,430 \\
$\quad$ Personal income tax 3/ & 45,308 & 69,230 & 100,028 & 138,925 & 152,865 \\
Domestic taxes on goods and services & 83,937 & 121,522 & 108,601 & 136,402 & 157,345 \\
$\quad$ Value-added tax & 58,470 & 91,789 & 108,601 & 136,402 & 157,345 \\
$\quad$ Taxes on petroleum products & 25,467 & 29,733 & 0 & 0 & 0 \\
Taxes on international trade and transactions & 115,703 & 194,744 & 201,408 & 234,793 & 252,154 \\
$\quad$ Import duties, excises, and fees 4/ & 101,521 & 170,549 & 181,408 & 195,462 & 217,154 \\
$\quad$ Customs levies 5/ & 14,182 & 24,195 & 20,000 & 39,331 & 35,000 \\
& & & & & \\
Nontax revenue & $1,350,867$ & $1,371,508$ & $1,320,115$ & $1,722,209$ & $2,587,819$ \\
Oil crude export proceeds & $1,001,068$ & 954,816 & 719,287 & 966,716 & $1,440,377$ \\
Royalty & 192,531 & 206,593 & 169,234 & 245,517 & 357,666 \\
Domestic crude 6/ & 96,430 & 134,037 & 304,238 & 386,356 & 635,424 \\
Federal government independent revenue 7/ & 37,828 & 44,335 & 68,134 & 54,164 & 58,894 \\
Upstream gas proceeds/Other oil & 23,010 & 31,727 & 59,223 & 69,455 & 95,457 \\
& & & & & \\
Memorandum item: & & & & & \\
Privatization proceeds & 18,104 & 85,800 & 19,698 & & \\
& & & & & \\
\hline
\end{tabular}

Sources: Federal Ministry of Finance; and staff estimates.

1/ Includes the Federal, state and local governments.

2/ Mainly company income tax collected by the Federal Inland Revenue Service Revenue.

3/ Consists of personal income tax, other taxes and fees collected by state governments.

The Federal Inland Revenue Service also collects a small amount of personal income tax from armed forces personnel and inhabitants of the Federal Capital Territory.

4/ Consists of import duties, excise duties, and fees that go directly to the Federation account.

$5 /$ Consists mainly of earmarked import levies of a 5 percent port development surcharge,

a 1 percent Nigerian Shippers Council surcharge, and a 1 percent Raw Materials Research and Development Council surcharge.

6/ Proceeds fom the sale of crude oil to domestic refineries.

$7 /$ Consists of dividends from public enterprises, directors' fees and loan recoveries. 
Table 12. Nigeria: Consolidated Government Expenditure, 2000-04 1/

(in millions of naira)

\begin{tabular}{lrrrrr}
\hline & & & & & \\
& 2000 & 2001 & 2002 & 2003 & 2004 \\
\hline Total expenditure & & & & & \\
Recurrent expenditure & $1,706,562$ & $2,509,965$ & $2,290,434$ & $2,889,658$ & $3,388,731$ \\
Goods and services & 651,615 & 770,120 & 868,107 & 906,651 & 967,770 \\
$\quad$ Federal government personnel costs & 350,078 & 403,073 & 477,596 & 514,371 & 570,640 \\
Federal government overhead & 278,701 & 285,169 & 368,484 & 367,950 & 442,562 \\
Customs levies & 71,377 & 117,904 & 109,112 & 146,422 & 128,078 \\
Education Fund & 14,182 & 24,195 & 20,000 & 39,331 & 35,000 \\
Interest payments due & 7,444 & 16,214 & 9,570 & 9,704 & 17,430 \\
$\quad$ Domestic interest & 279,911 & 326,638 & 360,941 & 343,245 & 344,700 \\
$\quad$ Foreign interest & 104,165 & 154,796 & 170,635 & 169,725 & 188,822 \\
Capital expenditure & 175,747 & 171,842 & 190,306 & 173,520 & 155,877 \\
Domestically-financed budgetary & 250,506 & 440,955 & 264,002 & 240,896 & 318,833 \\
Foreign financed & 233,762 & 433,070 & 251,078 & 230,886 & 288,900 \\
NNPC operations & 16,744 & 7,885 & 12,924 & 10,010 & 29,933 \\
JVC cash calls & 289,856 & 429,754 & 351,451 & 451,062 & 454,879 \\
NNPC priority projects & 267,736 & 391,680 & 345,604 & 451,062 & 454,879 \\
Extrabudgetary outlays/Other/NDDC & 22,119 & 38,074 & 5,848 & 0 & 0 \\
Judiciary & 0 & 10,000 & 22,171 & 54,958 & 55,865 \\
Net lending & 9,641 & 15,000 & 15,415 & 26,186 & 28,146 \\
& 0 & 0 & 7,400 & 0 & 0 \\
State and local governments & & & & $1,563,239$ \\
\hline
\end{tabular}

Sources: Federal Ministry of Finance and staff estimates.

1/ Consists of the Federal, state and local governments. 
Table 13. Nigeria: Federation Account Operations, 2000-04

(In millions of naira)

\begin{tabular}{|c|c|c|c|c|c|}
\hline & 2000 & 2001 & 2002 & 2003 & 2004 \\
\hline Total revenue & $1,007,585$ & $1,096,418$ & $1,171,447$ & $1,450,603$ & $1,993,740$ \\
\hline Petroleum revenue & 855,051 & 857,201 & 900,935 & $1,140,370$ & $1,646,458$ \\
\hline Foreign-generated oil and gas revenue (net) & 740,384 & 735,656 & 596,697 & 754,014 & $1,011,033$ \\
\hline Gross government export proceeds & 947,163 & 934,284 & 778,510 & $1,036,172$ & $1,535,835$ \\
\hline Royalty and petroleum profit tax & 525,073 & 639,234 & 393,232 & 683,481 & $1,183,510$ \\
\hline First charges / Deductions & $-731,852$ & $-837,862$ & $-575,045$ & $-965,638$ & $-1,708,311$ \\
\hline Domestically-generated oil revenue (net) & 114,667 & 121,545 & 304,238 & 386,356 & 635,424 \\
\hline Petroleum naira revenue & 114,667 & 121,545 & 304,238 & 386,356 & 635,424 \\
\hline Transfer to Petroleum Special Trust Fund & 0 & 0 & 0 & 0 & 0 \\
\hline Nonpetroleum revenue & 152,534 & 239,217 & 270,512 & 310,233 & 347,283 \\
\hline Company income tax & 51,028 & 68,660 & 89,104 & 114,770 & 130,129 \\
\hline Customs and excise & 101,506 & 170,557 & 181,408 & 195,462 & 217,154 \\
\hline Total expenditure & $1,020,954$ & $1,212,101$ & $1,167,331$ & $1,471,816$ & $1,987,352$ \\
\hline Federation account distribution 1/ & $1,020,954$ & $1,212,101$ & $1,167,331$ & $1,471,816$ & $1,987,352$ \\
\hline Federal government & 514,969 & 530,658 & 543,818 & 616,948 & 878,468 \\
\hline State government & 256,501 & 391,327 & 321,422 & 419,845 & 582,222 \\
\hline Local government & 213,751 & 245,487 & 269,446 & 346,866 & 448,868 \\
\hline Special funds & 35,733 & 44,629 & 32,644 & 88,157 & 77,794 \\
\hline Federal Capital Territory & 10,210 & 12,780 & 5,539 & 20,170 & 18,239 \\
\hline Ecology / Derivation and Ecology & 20,419 & 25,491 & 8,945 & 19,433 & 18,749 \\
\hline Statutory stabilization & 5,105 & 6,358 & 4,471 & 9,711 & 9,326 \\
\hline Derivation / Development of Natural Resources & 0 & 0 & 13,690 & 38,843 & 31,479 \\
\hline Mineral-producing areas & 0 & 0 & 0 & 0 & 0 \\
\hline Overall balance & $-13,369$ & $-115,683$ & 4,116 & $-21,213$ & 6,389 \\
\hline Financing & 13,369 & 115,683 & $-4,116$ & 21,213 & $-6,389$ \\
\hline \multicolumn{6}{|l|}{ Memorandum items: } \\
\hline First charges / Deductions & 731,852 & 837,862 & 575,045 & 965,638 & $1,708,311$ \\
\hline JVC cash calls & 260,000 & 391,990 & 345,604 & 451,062 & 454,879 \\
\hline NNPC priority projects & 24,750 & 38,074 & 5,848 & 0 & 0 \\
\hline External debt service & 175,034 & 232,192 & 143,063 & 235,657 & 235,027 \\
\hline National priority projects & 0 & 0 & 0 & 0 & 0 \\
\hline Special reserve/excess proceeds & 227,003 & 97,225 & 0 & 141,724 & 758,561 \\
\hline $13 \%$ natural resource derivation & 45,066 & 78,381 & 80,530 & 137,195 & 259,844 \\
\hline
\end{tabular}

Sources: Federal Ministry of Finance; and staff estimates.

1/ The current allocation formula of Federation account revenue is 48.5 percent for the Federal government, 24.9 percent for state governmen 20.6 percent for local governments, and 6 percent for special funds. 
Table 14. Nigeria: Summary Federal Government Fiscal Operations, 2000-04 1/

(in millions of naira, unless otherwise indicated)

\begin{tabular}{|c|c|c|c|c|c|}
\hline & 2000 & 2001 & 2002 & 2003 & 2004 \\
\hline Total revenue & $1,291,042$ & $1,322,229$ & $1,122,215$ & $1,420,819$ & $1,944,226$ \\
\hline Distribution from Federation account & 514,969 & 530,658 & 543,818 & 616,948 & 878,468 \\
\hline Drawdown of Federation stabilization account & 0 & 64 & 0 & 0 & 0 \\
\hline Federal government share of value-added tax & 8,770 & 13,359 & 15,747 & 19,778 & 22,815 \\
\hline Independent revenue $2 /$ & 38,057 & 44,405 & 68,134 & 54,164 & 58,894 \\
\hline Autonomous foreign exchange market profit & 0 & 0 & 0 & 0 & 0 \\
\hline Education Trust Fund & 8,302 & 16,214 & 9,570 & 9,704 & 17,430 \\
\hline Customs levies & 14,182 & 24,195 & 20,000 & 39,331 & 35,000 \\
\hline First charges/deductions & 729,246 & 680,070 & 494,515 & 729,929 & 984,049 \\
\hline External debt service & 175,034 & 232,192 & 143,063 & 210,130 & 197,307 \\
\hline National priority projects & 42,459 & 18,124 & 0 & 0 & 0 \\
\hline JVC cash calls and NNPC priority projects & 284,750 & 429,754 & 351,451 & 451,062 & 454,879 \\
\hline Excess proceeds & 227,003 & $\ldots$ & $\ldots$ & 68,736 & 331,863 \\
\hline Judiciary & 9,641 & $\ldots$ & $\ldots$ & $\ldots$ & $\ldots$ \\
\hline 13 percent derivation grant & 45,066 & $\ldots$ & 0 & 0 & 0 \\
\hline Transfer for Petroleum Special Trust Fund (PSTF) & 0 & 0 & 0 & 0 & 0 \\
\hline PSTF independent revenue $3 /$ & 0 & 0 & 0 & 0 & 0 \\
\hline Other & 0 & 53,737 & 0 & 0 & 0 \\
\hline Total expenditure & $1,220,744$ & $1,625,255$ & $1,389,170$ & $1,510,036$ & $1,559,326$ \\
\hline Recurrent expenditure & 684,850 & 762,016 & 719,956 & 791,656 & 843,615 \\
\hline Goods and services & 350,078 & 403,107 & 477,596 & 514,371 & 570,640 \\
\hline Personnel costs & 278,701 & 285,118 & 368,484 & 367,950 & 442,562 \\
\hline Overhead & 71,377 & 117,989 & 109,112 & 146,422 & 128,078 \\
\hline PSTF & 0 & 0 & 0 & 0 & 0 \\
\hline Interest payments due & 312,288 & 358,909 & 213,061 & 242,055 & 230,829 \\
\hline Domestic interest & 104,168 & 154,796 & 170,635 & 169,725 & 188,822 \\
\hline Foreign interest & 208,121 & 204,113 & 42,426 & 72,330 & 42,007 \\
\hline Local contractors & 0 & 0 & 0 & 0 & 0 \\
\hline Other & 22,484 & 0 & 29,299 & 35,230 & 42,146 \\
\hline Capital expenditure & 246,098 & 433,486 & 317,762 & 267,317 & 260,833 \\
\hline Domestically financed & 233,843 & 425,601 & 304,838 & 257,308 & 230,900 \\
\hline Budgetary & 176,825 & 403,567 & 304,838 & 257,308 & 230,900 \\
\hline National priority projects & 42,459 & 18,124 & 0 & 0 & 0 \\
\hline PSTF & 14,559 & 3,910 & 0 & 0 & 0 \\
\hline Foreign financed & 12,254 & 7,885 & 12,924 & 10,010 & 29,933 \\
\hline Net lending $4 /$ & 0 & 0 & 0 & 0 & 0 \\
\hline JVC cash calls and NNPC priority projects & 284,750 & 429,754 & 351,451 & 451,062 & 454,879 \\
\hline Other/Extra budgetary expenditure & 5,046 & 0 & 0 & 0 & 0 \\
\hline Overall balance (commitment basis) & 70,299 & $-303,027$ & $-266,955$ & $-89,217$ & 384,900 \\
\hline Balancing item & 13,300 & 0 & 0 & 0 & 0 \\
\hline Overall balance (cash basis) & 56,999 & $-303,027$ & $-266,955$ & $-89,217$ & 384,900 \\
\hline Financing & $-56,999$ & 303,027 & 266,955 & 89,217 & $-384,900$ \\
\hline Privatization & 18,104 & 0 & 0 & 0 & 0 \\
\hline External loans (net) & 45,341 & $-26,290$ & $-105,352$ & $-127,791$ & $-125,368$ \\
\hline Borrowings & 12,254 & 7,885 & 12,924 & 10,010 & 29,933 \\
\hline Amortization due & $-135,513$ & $-34,174$ & $-100,637$ & $-137,800$ & $-155,300$ \\
\hline Change in arrears (acc. + , red. -$)$ & 0 & 0 & 0 & 0 & 0 \\
\hline Rescheduling & 168,600 & 0 & $-17,639$ & 0 & 0 \\
\hline Domestic & $-102,340$ & 329,316 & 372,307 & 217,008 & $-259,532$ \\
\hline Banking system (net) 5/ & $-99,615$ & 118,724 & 398,848 & 298,567 & $-418,819$ \\
\hline Nonbank & $-2,725$ & $-30,216$ & $-26,541$ & $-81,560$ & 159,287 \\
\hline \multicolumn{6}{|l|}{ Memorandum items: } \\
\hline Primary balance 6/ & 382,587 & 55,882 & $-53,894$ & 152,838 & 615,729 \\
\hline Primary balance (in percent of GDP) & 8.2 & 1.0 & -1.0 & 2.0 & 6.4 \\
\hline GDP at market prices & $4,676,394$ & $5,339,063$ & $5,632,308$ & $7,532,915$ & $9,575,040$ \\
\hline
\end{tabular}

Source: Federal Ministry of Finance; and staff estimates.

1/ Consists of the Federal government and the Petroleum Special Trust Fund (PSTF).

2/ Consists of dividends from public enterprises, directors' fees and loan recoveries from public enterprises.

3/ Miscellaneous revenues.

3/ Consists of interest earned on PSTF balances held as deposits and treasury bills.

4/ To state governments.

5/ Includes adjustment for PSTF deposits held in the commercial and merchant banking system, which are classified as private deposits

6/ Primary balance is defined as total revenue less total expenditure, excluding interest payments due. 
Table 15. Nigeria: Total Expenditure of the Federal Government by Functional Classification, 2000-03 1/

\begin{tabular}{|c|c|c|c|c|}
\hline & 2000 & 2001 & 2002 & 2003 \\
\hline & \multicolumn{4}{|c|}{ (In millions of naira) } \\
\hline Administration & 174,578 & 230,065 & 405,313 & 395,807 \\
\hline General administration & 95,882 & 103,112 & 183,379 & 232,764 \\
\hline National Assembly & 6,655 & 19,813 & 21,635 & 24,395 \\
\hline Defense & 37,490 & 63,472 & 108,148 & 61,723 \\
\hline Internal security & 34,551 & 43,669 & 92,152 & 76,925 \\
\hline Economic services & 130,222 & 307,960 & 273,648 & 145,431 \\
\hline Agriculture and natural services & 13,609 & 64,944 & 44,804 & 16,045 \\
\hline Road and construction & 18,487 & 28,642 & 45,126 & 34,704 \\
\hline Manufacturing, mining, and quarrying & 10,514 & 7,284 & 39,663 & 584 \\
\hline Transport and communications & 9,605 & 53,176 & 53,663 & 29,309 \\
\hline Housing & 0 & 56,356 & 44,479 & 9,496 \\
\hline National priority projects & 40,377 & 18,124 & 0 & 0 \\
\hline JVC cash calls/NNPC priority projects & 0 & 0 & 0 & 0 \\
\hline Petroleum Trust Fund & 14,559 & 3,910 & 20 & 0 \\
\hline Counterpart funding & 7,028 & 0 & 0 & 411 \\
\hline Niger Delta Development Commission & 944 & 10,000 & 0 & 9,045 \\
\hline Others & 15,098 & 65,524 & 45,894 & 45,838 \\
\hline Social and community services & 86,768 & 189,326 & 266,378 & 167,798 \\
\hline Education & 49,563 & 59,745 & 109,455 & 79,436 \\
\hline Health & 20,445 & 44,652 & 63,171 & 39,686 \\
\hline Housing & 0 & 56,356 & 44,479 & 9,496 \\
\hline Other & 16,759 & 28,574 & 49,273 & 39,181 \\
\hline Transfers & 469,815 & 433,032 & 437,297 & 377,405 \\
\hline Outstanding domestic liabilities & 0 & 0 & 0 & 0 \\
\hline Interest due & 279,911 & 326,638 & 360,941 & 343,244 \\
\hline Domestic & 104,165 & 154,796 & 170,635 & 169,724 \\
\hline External & 175,747 & 171,842 & 190,306 & 173,520 \\
\hline Other recurrent tranfers $1 /$ & 143,206 & 30,046 & 76,355 & 34,150 \\
\hline Other capital transfers & 46,698 & 76,348 & 0 & 11 \\
\hline \multirow[t]{2}{*}{ Total } & 861,383 & $1,160,384$ & $1,382,636$ & $1,086,441$ \\
\hline & \multicolumn{4}{|c|}{ (In percent of total) } \\
\hline Administration & 20.3 & 19.8 & 29.3 & 36.4 \\
\hline General administration & 11.1 & 8.9 & 13.3 & 21.4 \\
\hline National Assembly & 0.8 & 1.7 & 1.6 & 2.2 \\
\hline Defense & 4.4 & 5.5 & 7.8 & 5.7 \\
\hline Internal security & $\begin{array}{l}4.0 \\
\text { U.v }\end{array}$ & $\begin{array}{l}3.8 \\
\text { U.U }\end{array}$ & $\begin{array}{l}6.7 \\
\text { U.u }\end{array}$ & $\begin{array}{l}7.1 \\
\text { U.v }\end{array}$ \\
\hline Economic services & 15.1 & 26.5 & 19.8 & 13.4 \\
\hline Agriculture and water services & 1.6 & 5.6 & 3.2 & 1.5 \\
\hline Construction & 2.1 & 2.5 & 3.3 & 3.2 \\
\hline Manufacturing, mining, and quarrying & 1.2 & 0.6 & 2.9 & 0.1 \\
\hline Transport and communications & 1.1 & 4.6 & 3.9 & 2.7 \\
\hline Housing & 0.0 & 4.9 & 3.2 & 0.9 \\
\hline National priority projects & 4.7 & 1.6 & 0.0 & 0.0 \\
\hline JVC cash calls/NNPC priority projects & 0.0 & 0.0 & 0.0 & 0.0 \\
\hline Petroleum Trust Fund & 1.7 & 0.3 & 0.0 & 0.0 \\
\hline Counterpart funding & 0.8 & 0.0 & 0.0 & 0.0 \\
\hline Niger Delta Development Commission & 0.1 & 0.9 & 0.0 & 0.8 \\
\hline Others & 1.8 & 5.6 & 3.3 & 4.2 \\
\hline Social and community services & 10.1 & 16.3 & 19.3 & 15.4 \\
\hline Education & 5.8 & 5.1 & 7.9 & 7.3 \\
\hline Health & 2.4 & 3.8 & 4.6 & 3.7 \\
\hline Housing & 0.0 & 4.9 & 3.2 & 0.9 \\
\hline Other & 1.9 & 2.5 & 3.6 & 3.6 \\
\hline Transfers & 54.5 & 37.3 & 31.6 & 34.7 \\
\hline Outstanding domestic liabilities & 0.0 & 0.0 & 0.0 & 0.0 \\
\hline Interest due & 32.5 & 28.1 & 26.1 & 31.6 \\
\hline Domestic & 12.1 & 13.3 & 12.3 & 15.6 \\
\hline External & 20.4 & 14.8 & 13.8 & 16.0 \\
\hline Other recurrent transfers 2/ & 16.6 & 2.6 & 5.5 & 3.1 \\
\hline Other capital transfers & 15.2 & 15.2 & 15.2 & 16.2 \\
\hline Total & 100 & 100 & 100 & 100 \\
\hline
\end{tabular}

Sources: Annual reports of the Central Bank of Nigeria and staff estimates of the interest due.

1/ Includes pensions, gratuities and contingencies. 
Table 16. Nigeria: Recurrent Expenditure of the Federal Government by Functional Classification, 2000-03

\begin{tabular}{|c|c|c|c|c|}
\hline & 2000 & 2001 & 2002 & 2003 \\
\hline & \multicolumn{4}{|c|}{ (In millions of naira) } \\
\hline Administration & 121,299 & 180,810 & 331,736 & 307,849 \\
\hline General administration & 59,332 & 75,080 & 146,807 & 166,058 \\
\hline National Assembly & 4,766 & 19,804 & 20,163 & 22,395 \\
\hline Defense & 31,046 & 47,072 & 86,054 & 51,044 \\
\hline Internal security & 26,154 & 38,855 & 78,713 & 68,352 \\
\hline Economic services & 29,816 & 53,011 & 65,911 & 96,032 \\
\hline Agriculture & 4,806 & 7,065 & 12,439 & 7,534 \\
\hline Road and construction & 11,480 & 7,202 & 9,276 & 16,945 \\
\hline Transport and communications & 2,428 & 33,935 & 36,579 & 22,670 \\
\hline Others & 11,102 & 4,809 & 7,616 & 48,883 \\
\hline Social and community services & 58,802 & 79,634 & 189,432 & 102,566 \\
\hline Education & 39,034 & 39,885 & 100,240 & 64,756 \\
\hline Health & 11,580 & 24,524 & 50,563 & 33,255 \\
\hline Others & 8,189 & 15,226 & 38,628 & 4,556 \\
\hline Transfers & 423,117 & 356,684 & 437,297 & 377,394 \\
\hline Interest due & 279,911 & 326,638 & 360,941 & 343,244 \\
\hline Domestic & 104,165 & 154,796 & 170,635 & 169,724 \\
\hline External & 175,747 & 171,842 & 190,306 & 173,520 \\
\hline Others 2/ & 143,206 & 30,046 & 76,355 & 34,150 \\
\hline \multirow[t]{2}{*}{ Total } & 633,035 & 670,140 & $1,024,375$ & 883,840 \\
\hline & & \multicolumn{3}{|c|}{ (In percent of total) } \\
\hline Administration & 19.2 & 27.0 & 32.4 & 34.8 \\
\hline General administration & 9.4 & 11.2 & 14.3 & 18.8 \\
\hline National Assembly & 0.8 & 3.0 & 2.0 & 2.5 \\
\hline Defense & 4.9 & 7.0 & 8.4 & 5.8 \\
\hline Internal security & 4.1 & 5.8 & 7.7 & 7.7 \\
\hline Economic services & 4.7 & 7.9 & 6.4 & 10.9 \\
\hline Agriculture and water & 0.8 & 1.1 & 1.2 & 0.9 \\
\hline Construction & 1.8 & 1.1 & 0.9 & 1.9 \\
\hline Transport and communications & 0.4 & 5.1 & 3.6 & 2.6 \\
\hline Others & 1.8 & 0.7 & 0.7 & 5.5 \\
\hline Social and community services & 9.3 & 11.9 & 18.5 & 11.6 \\
\hline Education & 6.2 & 6.0 & 9.8 & 7.3 \\
\hline Health & 1.8 & 3.7 & 4.9 & 3.8 \\
\hline Others & 1.3 & 2.3 & 3.8 & 0.5 \\
\hline Transfers & 66.8 & 53.2 & 42.7 & 42.7 \\
\hline Interest due & 44.2 & 48.7 & 35.2 & 38.8 \\
\hline Domestic & 16.5 & 23.1 & 16.7 & 19.2 \\
\hline External & 27.8 & 25.6 & 18.6 & 19.6 \\
\hline Others $1 /$ & 22.6 & 4.5 & 7.5 & 3.9 \\
\hline Total & 100.0 & 100.0 & 100.0 & 100.0 \\
\hline
\end{tabular}

Sources: Annual reports of the Central Bank of Nigeria, except for interest due estimated by the staff.

1/ Includes pensions, gratuities and contingencies . 
Table 17. Nigeria: Capital Expenditure of the Federal Government by Functional Classification, 2000-03 1/

\begin{tabular}{|c|c|c|c|c|}
\hline & 2000 & 2001 & 2002 & 2003 \\
\hline & \multicolumn{4}{|c|}{ (In millions of naira) } \\
\hline Administration & 53,280 & 49,255 & 73,577 & 87,959 \\
\hline General administration & 36,550 & 28,032 & 36,572 & 66,706 \\
\hline National Assembly & 1,889 & 9 & 1,472 & 2,000 \\
\hline Defense & 6,444 & 16,400 & 22,094 & 10,680 \\
\hline Internal security & 8,397 & 4,814 & 13,440 & 8,573 \\
\hline Economic services & 111,508 & 259,758 & 215,353 & 98,282 \\
\hline Agriculture and natural resources & 8,803 & 57,879 & 32,364 & 8,511 \\
\hline Road and construction & 7,006 & 21,440 & 35,850 & 17,759 \\
\hline Manufacuring, mining, and quarrying & 10,514 & 7,284 & 39,663 & 584 \\
\hline Transport and communications & 7,177 & 19,241 & 17,083 & 6,640 \\
\hline Housing & 0 & 56,356 & 44,479 & 9,496 \\
\hline National priority projects & 40,377 & 18,124 & 0 & 0 \\
\hline JVC cash calls/NNPC priority projects & 0 & 0 & 0 & 0 \\
\hline PTF & 14,559 & 3,910 & 20 & 0 \\
\hline Counterpart funding & 7,028 & 0 & 0 & 411 \\
\hline Niger Delta Development Commission & 944 & 10,000 & 0 & 9,045 \\
\hline Others & 15,098 & 65,524 & 45,894 & 45,838 \\
\hline Social and community services & 27,965 & 53,336 & 32,467 & 55,736 \\
\hline Education & 10,529 & 19,860 & 9,215 & 14,680 \\
\hline Health & 8,866 & 20,128 & 12,608 & 6,431 \\
\hline Others & 8,570 & 13,348 & 10,644 & 34,625 \\
\hline Transfers & 46,698 & 76,348 & 0 & 11 \\
\hline Outstanding domestic liabilities & 0 & 0 & 0 & 0 \\
\hline Other & 46,698 & 76,348 & 0 & 11 \\
\hline \multirow[t]{2}{*}{ Total } & 239,451 & 438,697 & 321,398 & 241,989 \\
\hline & \multicolumn{4}{|c|}{ (In percent of total) } \\
\hline Administration & 22.3 & 11.2 & 22.9 & 36.3 \\
\hline General administration & 15.3 & 6.4 & 11.4 & 27.6 \\
\hline National Assembly & 0.8 & 0.0 & 0.5 & 0.8 \\
\hline Defense & 2.7 & 3.7 & 6.9 & 4.4 \\
\hline Internal security & 3.5 & 1.1 & 4.2 & 3.5 \\
\hline Economic services & 46.6 & 59.2 & 67.0 & 40.6 \\
\hline Agriculture and water resources & 3.7 & 13.2 & 10.1 & 3.5 \\
\hline Road and construction & 2.9 & 4.9 & 11.2 & 7.3 \\
\hline Manufacuring, mining, and quarrying & 4.4 & 1.7 & 12.3 & 0.2 \\
\hline Transport and communications & 3.0 & 4.4 & 5.3 & 2.7 \\
\hline Housing & 0.0 & 12.8 & 13.8 & 3.9 \\
\hline National priority projects & 16.9 & 4.1 & 0.0 & 0.0 \\
\hline JVC cash calls/NNPC priority projects & 0.0 & 0.0 & 0.0 & 0.0 \\
\hline PTF & 6.1 & 0.9 & 0.0 & 0.0 \\
\hline Counterpart funding & 2.9 & 0.0 & 0.0 & 0.2 \\
\hline Niger Delta Development Commission & 0.4 & 2.3 & 0.0 & 3.7 \\
\hline Others & 6.3 & 14.9 & 14.3 & 18.9 \\
\hline Social and community services & 11.7 & 12.2 & 10.1 & 23.0 \\
\hline Education & 4.4 & 4.5 & 2.9 & 6.1 \\
\hline Health & 3.7 & 4.6 & 3.9 & 2.7 \\
\hline Others & 3.6 & 3.0 & 3.3 & 14.3 \\
\hline Transfers & 19.5 & 17.4 & 0.0 & 0.0 \\
\hline Outstanding domestic liabilities & 0.0 & 0.0 & 0.0 & 0.0 \\
\hline Other & 19.5 & 17.4 & 0.0 & 0.0 \\
\hline Total & 100.0 & 100.0 & 100.0 & 100.0 \\
\hline
\end{tabular}

Source: Annual reports of the Central Bank of Nigeria.

1/ The figures are based on budgetary data and exclude extrabudgetary expenditure. 





Table 19. Nigeria: Summary of Budgetary Operations of State and Local Governments and special funds, 2000-03 1/

\begin{tabular}{|c|c|c|c|c|}
\hline & 2000 & 2001 & 2002 & 2003 \\
\hline & \multicolumn{4}{|c|}{ (In millions of naira) } \\
\hline Revenue & 501,953 & 727,557 & 832,072 & $1,220,541$ \\
\hline Statutory share of Federation account revenue 2/ & 368,544 & 523,470 & 518,864 & 828,696 \\
\hline \multicolumn{5}{|l|}{ Statutory share of Federation stabilization } \\
\hline account revenue & 5,781 & 7,061 & 9,570 & 996 \\
\hline Share of value-added tax & 44,197 & 64,233 & 71,359 & 105,535 \\
\hline State allocation & 0 & 0 & 0 & 0 \\
\hline Independent revenue 3 / & 45,308 & 69,230 & 100,028 & 138,925 \\
\hline Other & 38,123 & 63,563 & 132,252 & 146,389 \\
\hline Expenditure 4/ & 355,680 & 529,930 & 894,357 & $1,282,921$ \\
\hline Recurrent & 196,784 & 294,710 & 565,765 & 808,772 \\
\hline Capital & 158,896 & 235,220 & 328,592 & 474,149 \\
\hline Balance (deficit -) & 146,273 & 197,627 & $-62,286$ & $-62,380$ \\
\hline Financing & $-146,273$ & $-197,627$ & 62,286 & 62,380 \\
\hline Foreign loans & 156 & 0 & 15,879 & 14,680 \\
\hline Domestic loans & 3,835 & 0 & 32,452 & 71,030 \\
\hline Other (Residual) 5/ & $-150,264$ & $-197,627$ & 13,955 & $-23,330$ \\
\hline
\end{tabular}

Source: Central Bank of Nigeria (Annual reports).

1/ These data, obtained through annual surveys undertaken by the Central Bank of Nigeria, are only illustrative.

2/ This revenue is on gross basis (ie. before deductions for payments of various commitments made by the sub national gover 3/ Mainly personal income tax collected by state governments.

4/ Total spending is underestimated because only a sample of local governments are covered and deductions at source may nc have been included.

5/ Reflects an underestimation of expenditure. 
Table 20. Nigeria: Liquidity of Commercial Banks, 2000-04

\begin{tabular}{|c|c|c|c|c|c|}
\hline & 2000 & 2001 & 2002 & 2003 & 2004 \\
\hline & \multicolumn{5}{|c|}{ (In millions of naira) } \\
\hline Total liquid assets & 398,254 & 477,317 & 747,621 & 600,539 & 820,726 \\
\hline Cash in vault (currency) & 34,976 & 64,835 & 76,211 & 90,099 & 87,217 \\
\hline Reserves with central bank $1 /$ & 127,787 & 239,605 & 223,126 & 227,998 & 214,897 \\
\hline \multicolumn{6}{|l|}{ Of which: } \\
\hline Reserve requirements & 77,782 & 125,258 & 139,702 & 152,276 & 165,303 \\
\hline Current accounts & 54,872 & 94,359 & 105,320 & 120,025 & 111,673 \\
\hline Net interbank positions & $-39,748$ & 368 & $-11,232$ & $-55,289$ & $-52,805$ \\
\hline Balances held with other banks (net) & 37,086 & 54,872 & 51,377 & 42,881 & 82,470 \\
\hline Interbank placements (net) & 11,786 & 3,239 & 4,933 & 9,836 & $-11,411$ \\
\hline Money at call (net) & $-1,086$ & $-5,305$ & $-10,547$ & $-10,880$ & 1,012 \\
\hline Uncleared effects & $-87,534$ & $-52,438$ & $-56,996$ & $-97,126$ & $-124,876$ \\
\hline Treasury bills & 275,774 & 173,107 & 460,229 & 338,116 & 572,426 \\
\hline Treasury certificates & 0 & 0 & 0 & 750 & 0 \\
\hline Other liquid assets 2 / & -534 & -598 & -712 & $-1,135$ & $-1,009$ \\
\hline Certificate deposits (net) & -572 & -627 & -877 & $-1,138$ & $-1,044$ \\
\hline Bills discounted & 38 & 30 & 165 & 4 & 36 \\
\hline Free liquid assets & 320,472 & 352,059 & 607,919 & 448,264 & 655,423 \\
\hline Total deposit liabilities & 702,105 & 947,183 & $1,157,112$ & $1,337,296$ & $1,661,482$ \\
\hline Demand deposits & 345,001 & 448,021 & 503,870 & 577,664 & 728,552 \\
\hline Time, savings, and foreign currency deposits & 357,103 & 499,162 & 653,241 & 759,633 & 932,930 \\
\hline & & & (In percent) & & \\
\hline \multicolumn{6}{|l|}{ Liquidity reserve ratios 3 / } \\
\hline Actual & 45.6 & 37.2 & 52.5 & 33.5 & 39.4 \\
\hline Required & 30.0 & 40.0 & 40.0 & 42.0 & 42.0 \\
\hline \multicolumn{6}{|l|}{ Cash reserves (deposits at the CBN) } \\
\hline In percent of demand deposits & 37.0 & 53.5 & 44.3 & 39.5 & 29.5 \\
\hline In percent of total deposit liabilities & 18.2 & 25.3 & 19.3 & 17.0 & 12.9 \\
\hline Required 4/ & 10.0 & 12.5 & 12.5 & 14.5 & 14.5 \\
\hline
\end{tabular}

Source: Central Bank of Nigeria.

1/ As reported by the commercial banks.

2/ Comprising certificates of deposit, and bills discounted.

3/ Total liquid assets less penalty and cash reserve requirements as a percent of total deposit liabilities.

4/ The base to calculate the reserve requirement comprises banks' total deposit liabilities (i.e., demand, savings, and time deposits) except foreign currency deposits; certificate of deposits; promissory notes held by the non-bank public; bankers' acceptances and since January 2002, VAT and customs dutires collected by banks on behalf of the federal government held more than for seven days. Starting in 2002, the CRR's maintenance period was changed from 30 to 15 days. Cash must be held in a separate account with the CBN. Vault cash is not an eligible asset. 
Table 21. Nigeria: Selected Interest Rates, 2000-04

(In percent; end of period)

\begin{tabular}{|c|c|c|c|c|c|c|c|c|}
\hline & \multirow[b]{2}{*}{2000} & \multirow[b]{2}{*}{2001} & \multirow[b]{2}{*}{2002} & \multirow[b]{2}{*}{2003} & \multicolumn{4}{|c|}{2004} \\
\hline & & & & & Q1 & Q2 & Q3 & Q4 \\
\hline Minimum rediscount rate & 14.0 & 20.5 & 16.5 & 15.0 & 15.0 & 15.0 & 15.0 & 15.0 \\
\hline Treasury bill rate (stop rate) & 13.0 & 20.3 & 13.8 & 14.9 & 14.0 & 14.3 & 14.4 & 14.3 \\
\hline Seven-day Nibor & 15.9 & 25.3 & 15.1 & 20.8 & 16.9 & 17.6 & 15.2 & 16.3 \\
\hline Savings deposit rate $1 /$ & 4.9 & 5.0 & 3.7 & 3.2 & 5.7 & 3.3 & 4.4 & 4.4 \\
\hline Prime lending rate $1 /$ & 19.5 & 26.0 & 20.6 & 19.6 & 19.5 & 19.2 & 19.0 & 18.9 \\
\hline
\end{tabular}

Source: Central Bank of Nigeria.

1/ At commercial banks. 
Table 22. Nigeria: Imports, 2000-03 1/

\begin{tabular}{|c|c|c|c|c|}
\hline & 2000 & 2001 & 2002 & 2003 \\
\hline & \multicolumn{4}{|c|}{ (In millions of U.S. dollars) } \\
\hline Imports from the world & 5,823 & 7,926 & 8,727 & 14,936 \\
\hline Industrial countries & 3,903 & 4,904 & 5,114 & 7,849 \\
\hline United States & 660 & 816 & 1,121 & 2,315 \\
\hline Japan & 284 & 360 & 432 & 364 \\
\hline France & 325 & 372 & 363 & 480 \\
\hline Germany & 594 & 781 & 531 & 1,088 \\
\hline Italy & 272 & 201 & 260 & 636 \\
\hline Netherlands & 252 & 392 & 278 & 320 \\
\hline United Kingdom & 755 & 1,070 & 1,095 & 1,420 \\
\hline Africa & 244 & 712 & 398 & 747 \\
\hline \multicolumn{5}{|l|}{ Of which } \\
\hline Côte d'Ivoire & 17 & 57 & 5 & 11 \\
\hline Ghana & 14 & 12 & 18 & 22 \\
\hline Niger & 1 & 0 & 1 & 1 \\
\hline South Africa & 68 & 231 & 189 & 291 \\
\hline Asia (excluding Japan) & 1,003 & 1,648 & 2,522 & 2,759 \\
\hline China, P.R.: Mainland & 253 & 527 & 739 & 1,067 \\
\hline China, P.R.: Hong Kong & 88 & 96 & 108 & 153 \\
\hline India & 199 & 316 & 310 & 377 \\
\hline Indonesia & 45 & 108 & 108 & 123 \\
\hline Korea & 127 & 223 & 311 & 434 \\
\hline Singapore & 61 & 104 & 498 & 79 \\
\hline Thailand & 114 & 116 & 174 & 139 \\
\hline Other & 673 & 663 & 694 & 3,580 \\
\hline Russia & 195 & 116 & 91 & 145 \\
\hline Turkey & 19 & 21 & 28 & 24 \\
\hline Ukraine & 16 & 49 & 41 & 88 \\
\hline Brazil & 179 & 175 & 180 & 183 \\
\hline & \multicolumn{4}{|c|}{ (In percent of total) } \\
\hline Industrial Countries & 67.0 & 61.9 & 58.6 & 52.6 \\
\hline Africa & 4.2 & 9.0 & 4.6 & 5.0 \\
\hline Asia & 17.2 & 20.8 & 28.9 & 18.5 \\
\hline Other & 11.6 & 8.4 & 8.0 & 24.0 \\
\hline & \multicolumn{4}{|c|}{ (In millions of U.S. dollars) } \\
\hline \multicolumn{5}{|l|}{ Memorandum items: } \\
\hline Total merchandise imports in BoP & -671 & -738 & -735 & -877 \\
\hline
\end{tabular}

Sources: IMF, Direction of Trade statistics, and staff estimates.

1/ c.i.f. basis, based on partner-country data. 
Table 23. Nigeria: Exports, 2000-03 1/

\begin{tabular}{|c|c|c|c|c|}
\hline & 2000 & 2001 & 2002 & 2003 \\
\hline & \multicolumn{4}{|c|}{ (In millions of U.S. dollars) } \\
\hline World & 27,042 & 18,045 & 18,340 & 24,061 \\
\hline Industrial countries & 18,431 & 12,196 & 11,037 & 16,276 \\
\hline \multicolumn{5}{|l|}{ Of which: } \\
\hline United States & 11,495 & 7,320 & 5,819 & 9,205 \\
\hline Canada & 615 & 357 & 229 & 753 \\
\hline Japan & 109 & 173 & 549 & 965 \\
\hline Austria & 0 & 0 & 0 & 0 \\
\hline France & 1,657 & 1,142 & 997 & 1,359 \\
\hline Germany & 112 & 244 & 365 & 505 \\
\hline Netherlands & 253 & 365 & 288 & 535 \\
\hline Portugal & 686 & 461 & 491 & 589 \\
\hline Spain & 2,345 & 1,175 & 1,019 & 1,483 \\
\hline Switzerland & 0 & 1 & 0 & 27 \\
\hline United Kingdom & 7 & 45 & 11 & 96 \\
\hline Africa & 1,901 & 1,146 & 1,732 & 2,010 \\
\hline \multicolumn{5}{|l|}{ Of which: } \\
\hline Cameroon & 246 & 125 & 113 & 313 \\
\hline Côte d'Ivoire & 842 & 341 & 270 & 360 \\
\hline Ghana & 262 & 271 & 379 & 454 \\
\hline Senegal & 247 & 175 & 119 & 254 \\
\hline South Africa & 266 & 198 & 388 & 589 \\
\hline Asia & 5,254 & 3,067 & 3,525 & 3,634 \\
\hline \multicolumn{5}{|l|}{ Of which: } \\
\hline China,P.R.: Mainland & 140 & 127 & 73 & 123 \\
\hline India & 3,919 & 2,083 & 2,157 & 2,392 \\
\hline Indonesia & 606 & 537 & 961 & 770 \\
\hline Korea & 231 & 75 & 41 & 100 \\
\hline Other & 1,456 & 1,635 & 2,046 & 2,141 \\
\hline \multicolumn{5}{|l|}{ Of which: } \\
\hline Turkey & 0 & 0 & 0 & 0 \\
\hline Brazil & 667 & 1,051 & 1,538 & 1,636 \\
\hline \multirow[t]{2}{*}{ Chile } & 281 & 110 & 141 & 86 \\
\hline & \multicolumn{4}{|c|}{ (In percent of total) } \\
\hline Industrial Countries & 68 & 68 & 60 & 68 \\
\hline Africa & 7 & 6 & 9 & 8 \\
\hline Asia & 19 & 17 & 19 & 15 \\
\hline Other & 5 & 9 & 11 & 9 \\
\hline & \multicolumn{4}{|c|}{ (In millions of U.S. dollars) } \\
\hline \multicolumn{5}{|l|}{ Memorandum items: } \\
\hline Total merchandise exports in BoP & 23,761 & 19,598 & 17,672 & 27,250 \\
\hline of which: oil exports & 23,093 & 18,927 & 16,935 & 26,515 \\
\hline
\end{tabular}

Source: IMF, Direction of Trade statistics, and staff estimates.

1/ f.o.b. basis, based on partner country data. 
Table 24. Nigeria: External Public Debt Stock, 2000-03 1/

\begin{tabular}{|c|c|c|c|c|}
\hline & 2000 & 2001 & 2002 & 2003 \\
\hline & \multicolumn{4}{|c|}{ (In millions of U.S. dollars) } \\
\hline Multilateral & 3,342 & 3,037 & 2,961 & 3,042 \\
\hline World Bank & 2,149 & 1,958 & 1,951 & 1,988 \\
\hline African Development Bank & 990 & 909 & 838 & 873 \\
\hline Other (including arrears) & 203 & 170 & 172 & 181 \\
\hline Bilateral & 23,296 & 23,211 & 25,384 & 27,472 \\
\hline Paris Club 2/ & 23,272 & 23,199 & 25,381 & 27,470 \\
\hline Medium- and long-term debt & 23,272 & 22,831 & 22,966 & 23,897 \\
\hline Pre-cutoff & 21,731 & 21,058 & $\ldots$ & $\ldots$ \\
\hline Post cutoff & 1,541 & 1,774 & $\ldots$ & $\ldots$ \\
\hline Arrears (pre- and post cut-off) & 0 & 368 & 2,415 & 3,573 \\
\hline Other bilateral & 24 & 11 & 3 & 2 \\
\hline Commercial & 3,596 & 3,438 & 2,648 & 2,403 \\
\hline Par bonds (London Club debt) & 2,043 & 2,043 & 1,442 & 1,442 \\
\hline Promissory notes & 1,446 & 1,292 & 1,153 & 911 \\
\hline Other (including arrears) & 107 & 103 & 53 & 50 \\
\hline \multirow[t]{2}{*}{ Total } & 30,234 & 29,686 & 30,993 & 32,917 \\
\hline & \multicolumn{4}{|c|}{ (In percent of total) } \\
\hline Multilateral & 11.1 & 10.2 & 9.6 & 9.2 \\
\hline World Bank & 7.1 & 6.6 & 6.3 & 6.0 \\
\hline African Development Bank & 3.3 & 3.1 & 2.7 & 2.7 \\
\hline Other & 0.7 & 0.6 & 0.6 & 0.5 \\
\hline Bilateral & 77.1 & 78.2 & 81.9 & 83.5 \\
\hline Paris Club 2/ & 77.0 & 78.1 & 81.9 & 83.5 \\
\hline Other bilateral & 0.1 & 0.0 & 0.0 & 0.0 \\
\hline Commercial & 11.9 & 11.6 & 8.5 & 7.3 \\
\hline Par bonds & 6.8 & 6.9 & 4.7 & 4.4 \\
\hline Promissory notes & 4.8 & 4.4 & 3.7 & 2.8 \\
\hline
\end{tabular}

Sources: Nigerian authorities; Paris Club; and Fund staff estimates.

1/ In 2000-03, as reported by creditors. These figures are tentative pending the reconciliation of Nigeria's obligations with Paris Club creditors. In 2004, as reported by DMO.

2/ In 2000, including late interest as reported by the Paris Club and capitalized moratorium interest as estimated by Fund staff. 
Table 25. Nigeria: External Debt Service 2000-03

\begin{tabular}{|c|c|c|c|c|}
\hline & 2000 & 2001 & 2002 & 2003 \\
\hline Total debt service due & 3,434 & 3,248 & 2,931 & 2,936 \\
\hline Interest payments due before rescheduling & 1,719 & 1,535 & 1,557 & 1,569 \\
\hline Multilateral & 187 & 132 & 143 & 142 \\
\hline Bilateral & 1,345 & 1,204 & 1,224 & 1,285 \\
\hline Commercial & 187 & 199 & 191 & 142 \\
\hline Amortization payments before rescheduling & 1,715 & 1,713 & 1,373 & 1,368 \\
\hline Multilateral & 423 & 364 & 331 & 367 \\
\hline Bilateral & 1,166 & 1,225 & 914 & 876 \\
\hline Commercial & 126 & 124 & 129 & 124 \\
\hline Rescheduling (principal, interest) & 22,102 & 746 & $\cdots$ & .. \\
\hline current maturities & 247 & 149 & $\ldots$ & ... \\
\hline arrears & 21,362 & 0 & $\ldots$ & ... \\
\hline capitalized moratorium interest & 493 & 597 & $\ldots$ & $\ldots$ \\
\hline Flow accumulation of arrears & $-20,381$ & 375 & 1,900 & 1,127 \\
\hline Cash Debt Service Payments: & 1,714 & 2,127 & 1,031 & 1,809 \\
\hline Multilaterals & 610 & 497 & 474 & 509 \\
\hline Bilaterals & 790 & 1,308 & 237 & 1,034 \\
\hline Paris Club & 725 & 1,274 & 162 & 1,021 \\
\hline Other bilaterals & 66 & 35 & 76 & 13 \\
\hline Commercial banks & 313 & 322 & 320 & 267 \\
\hline Brady bonds & 129 & 134 & 128 & 90 \\
\hline Promisory notes & 185 & 188 & 192 & 176 \\
\hline Debt conversion program & 58 & 27 & 22 & 18 \\
\hline Cash interest paid & 815 & 1,823 & 350 & 548 \\
\hline Cash principal paid & 898 & 304 & 680 & 1,262 \\
\hline
\end{tabular}

Sources: Central Bank of Nigeria; Debt Management Office; Creditors; and Fund staff estimates. 


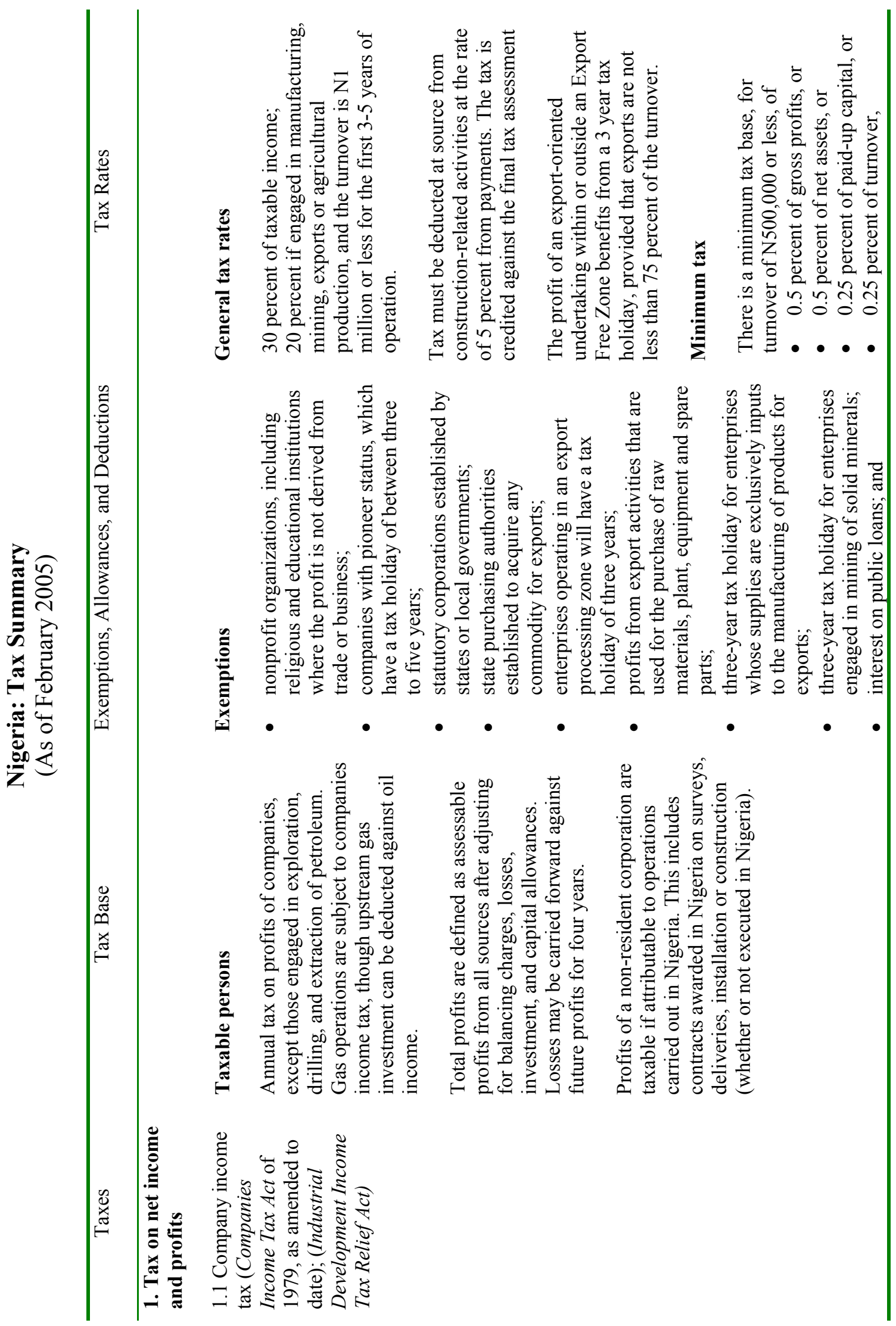




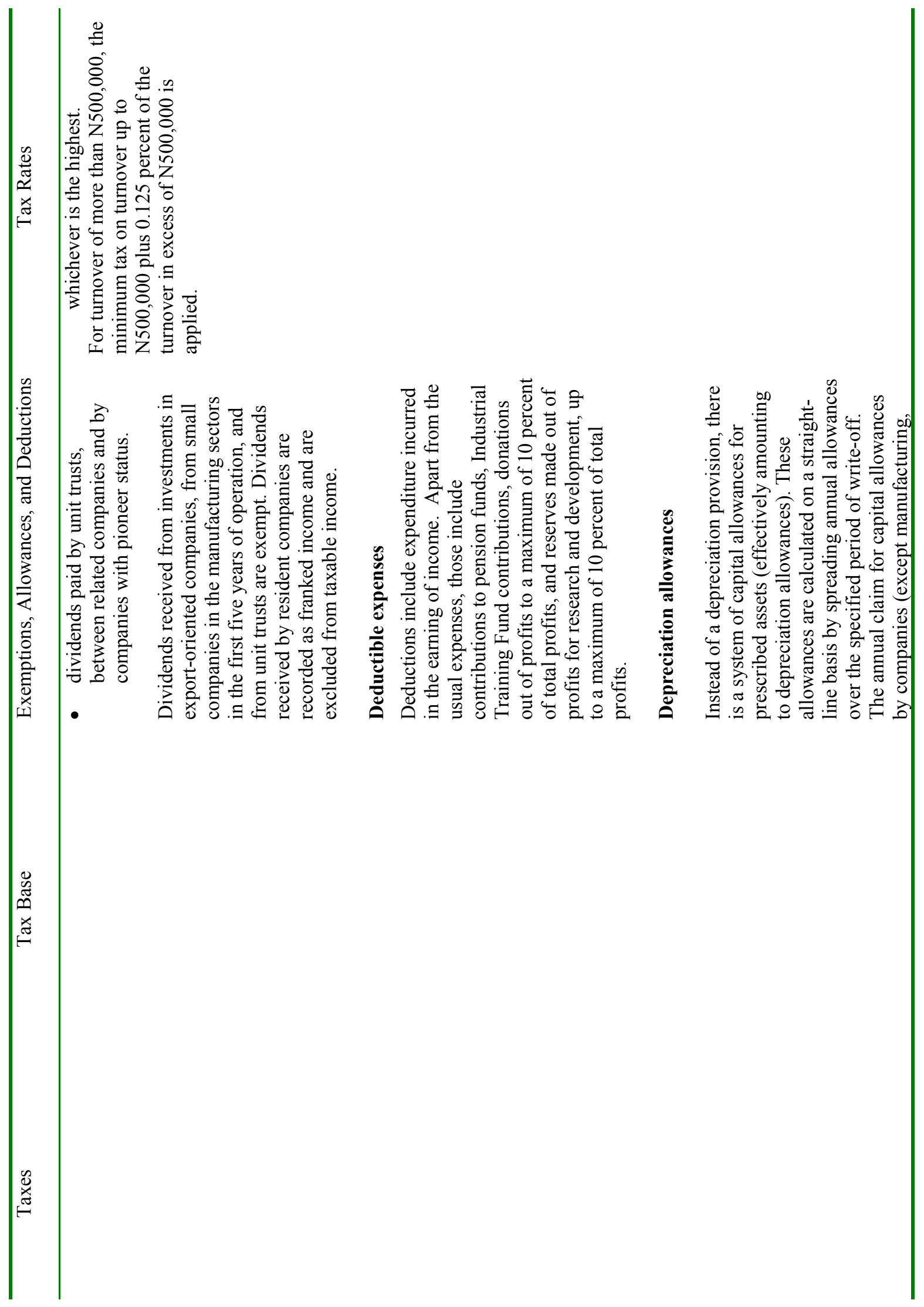




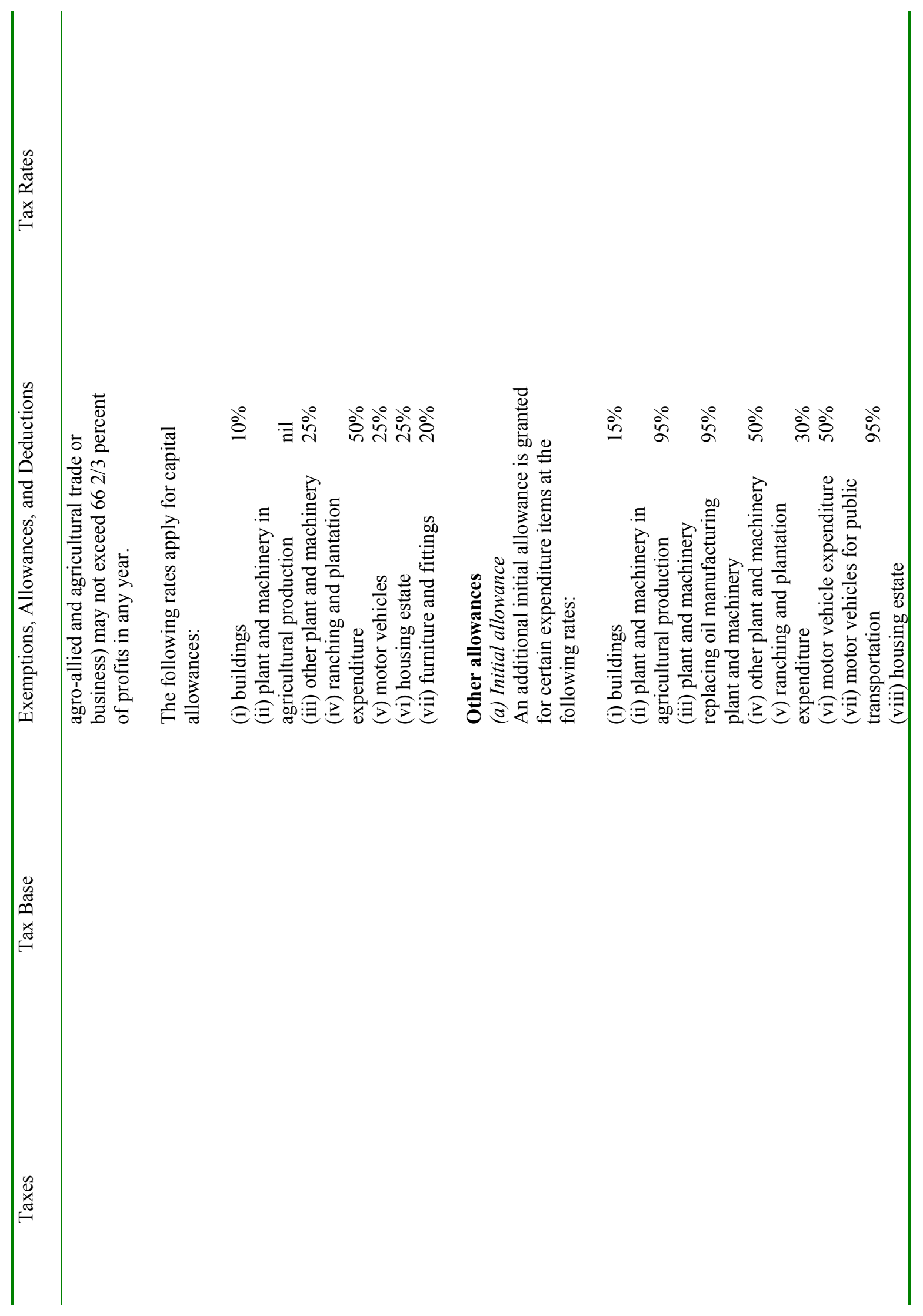


- 99 -

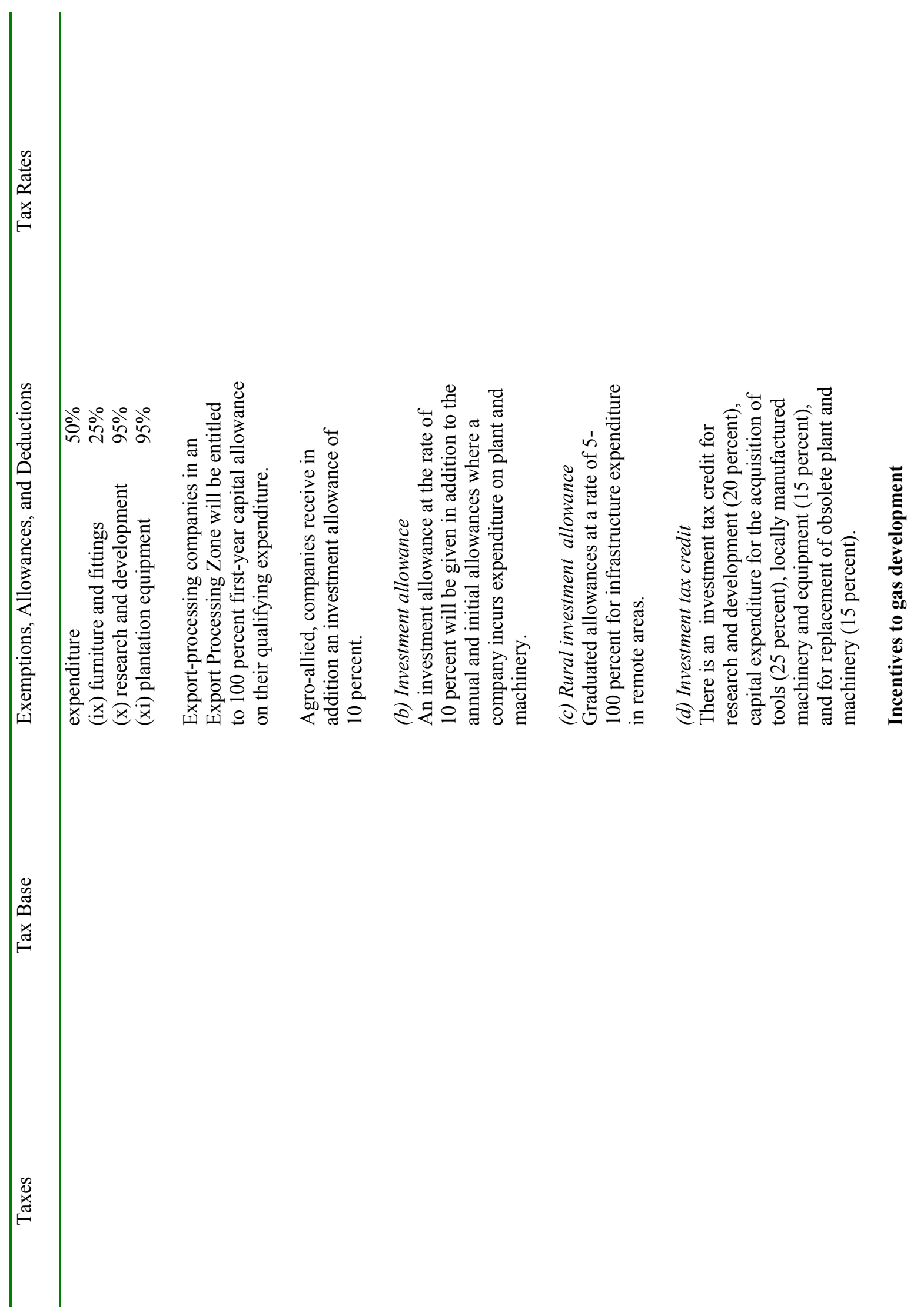




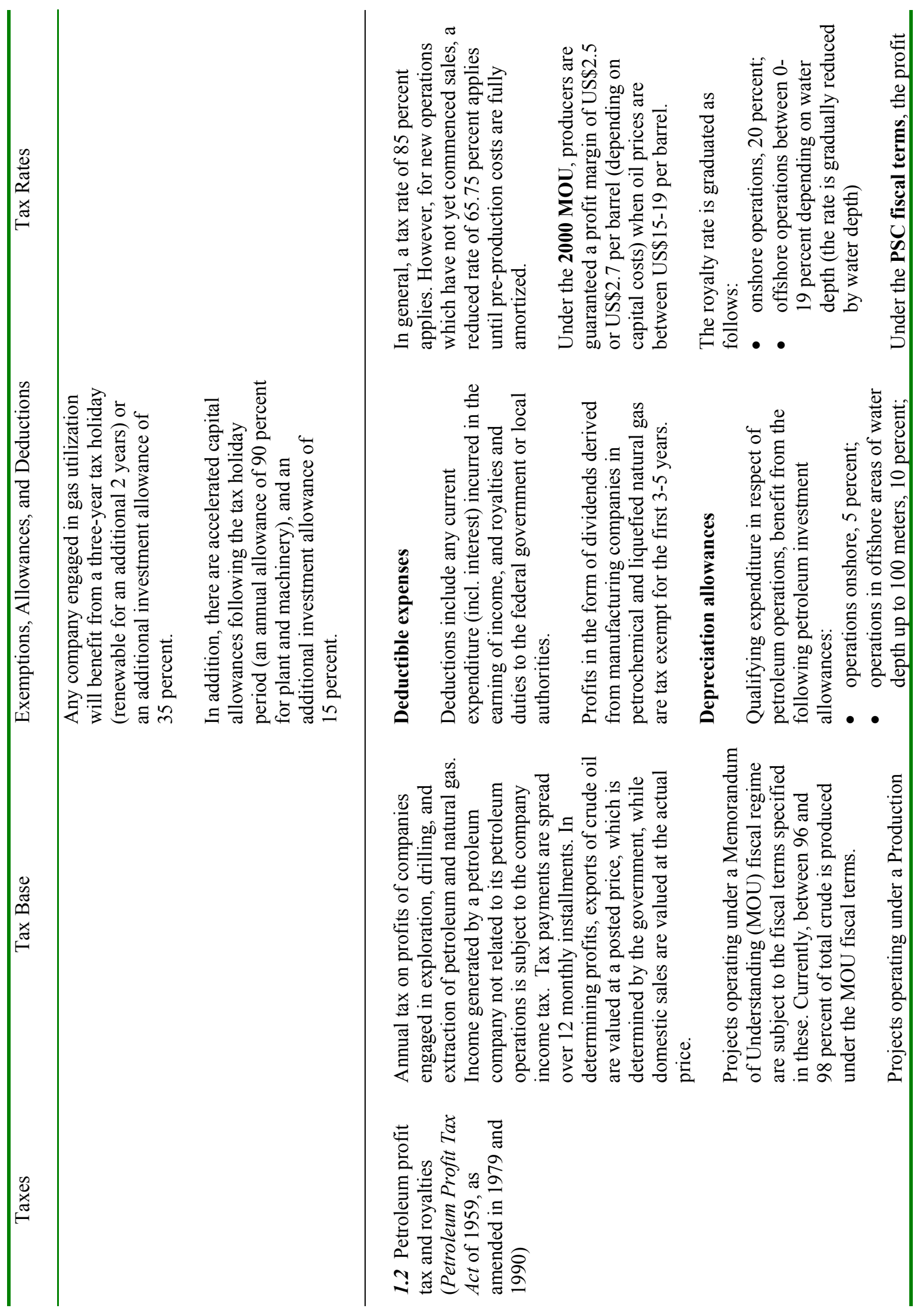




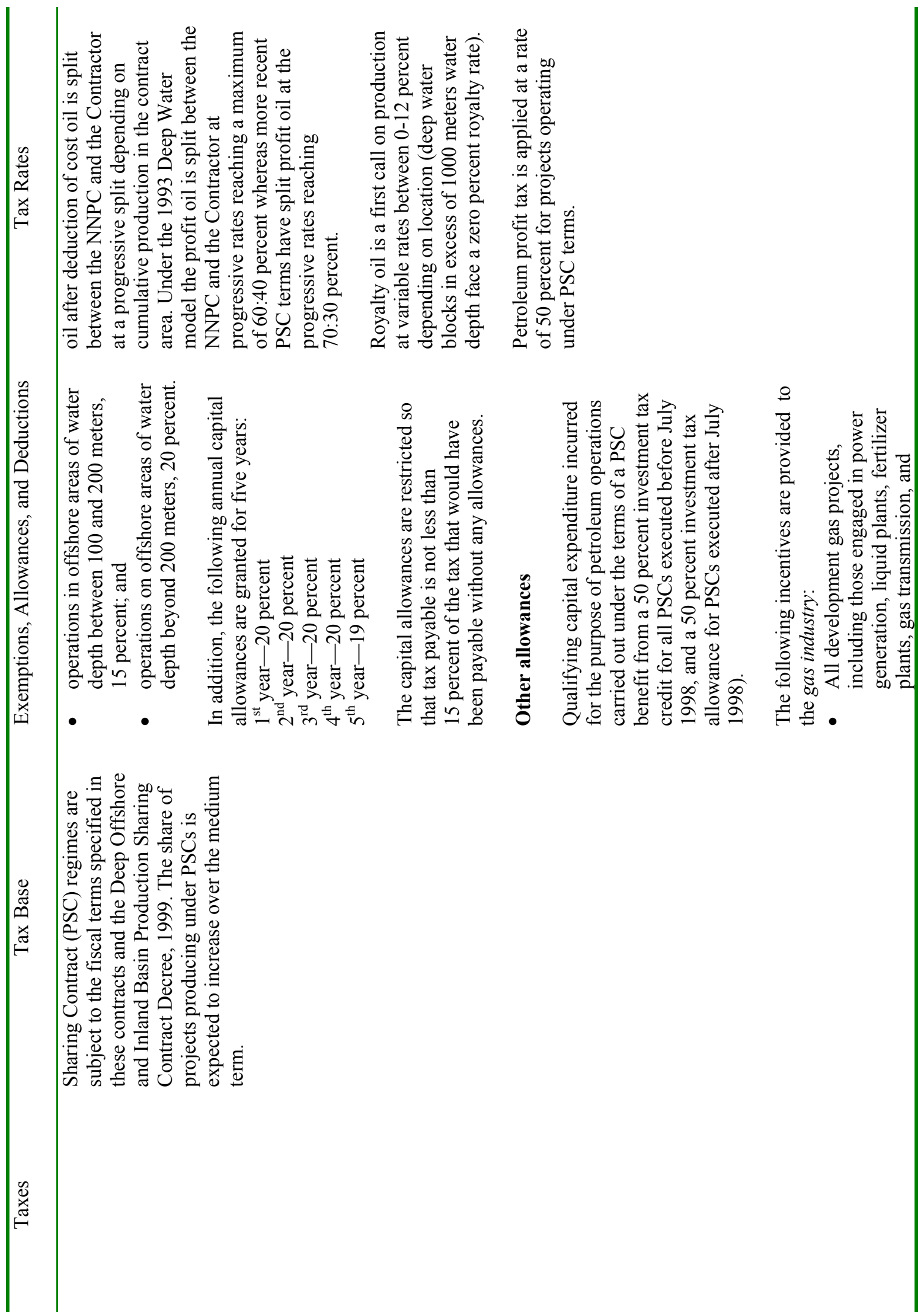




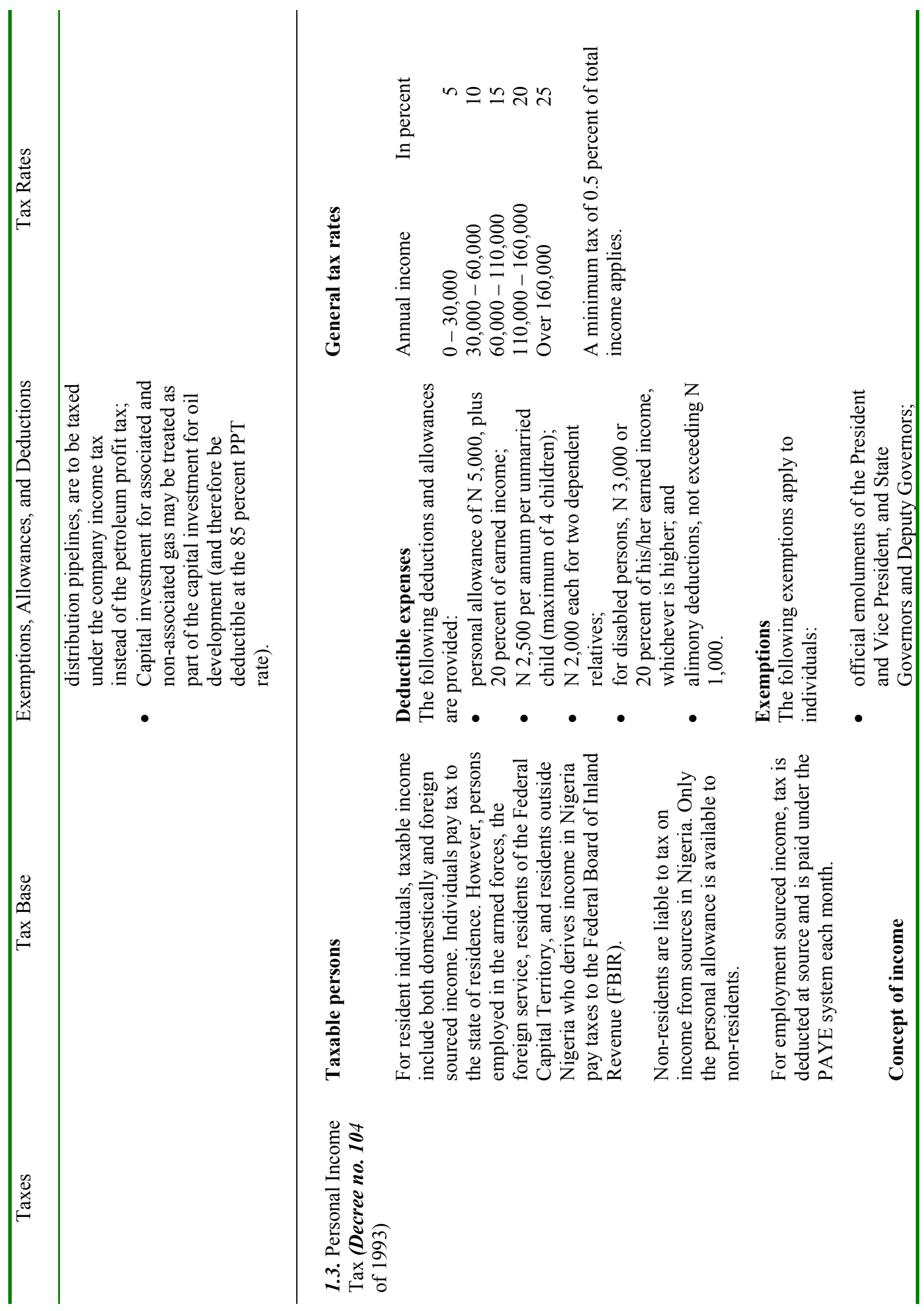




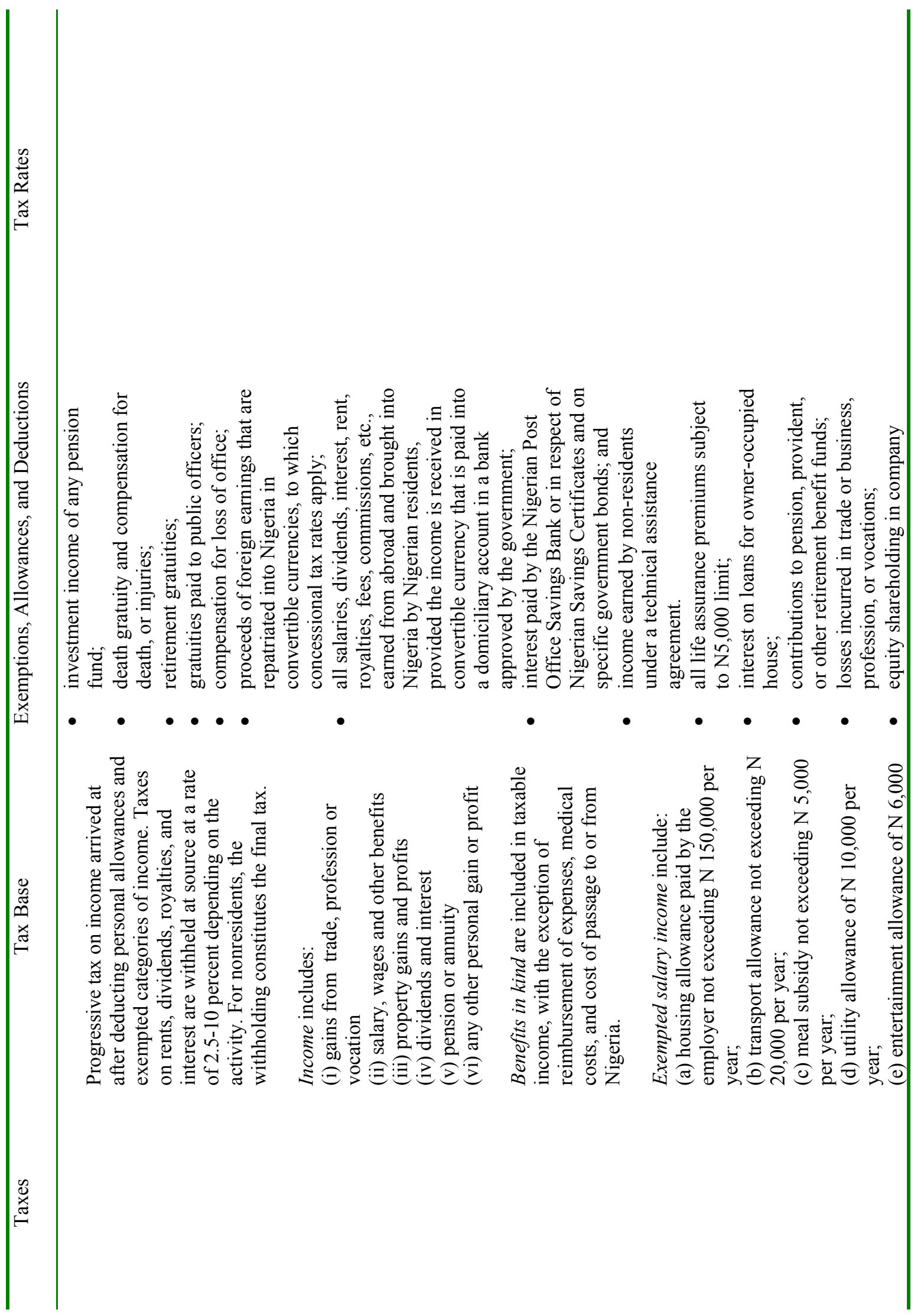




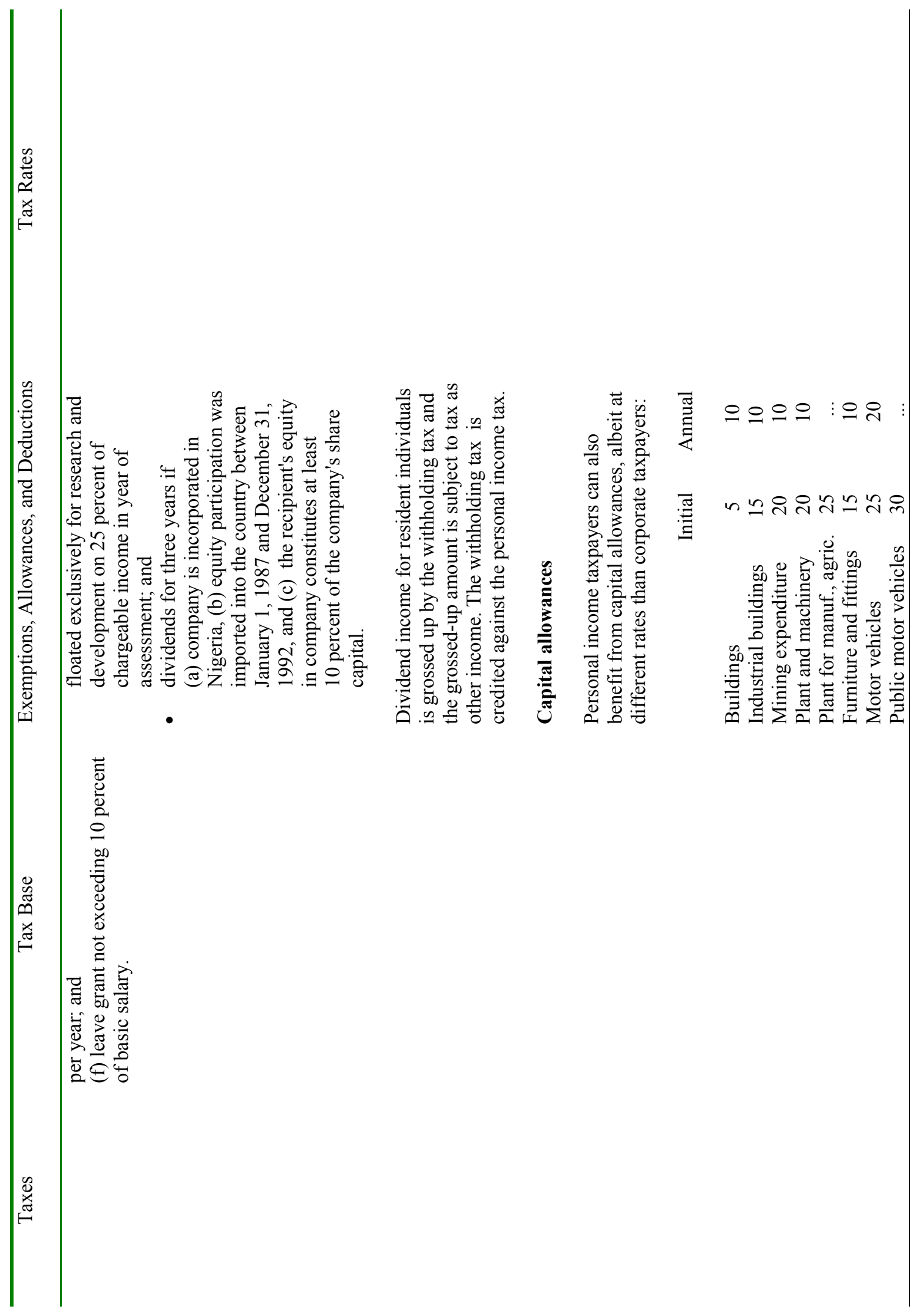




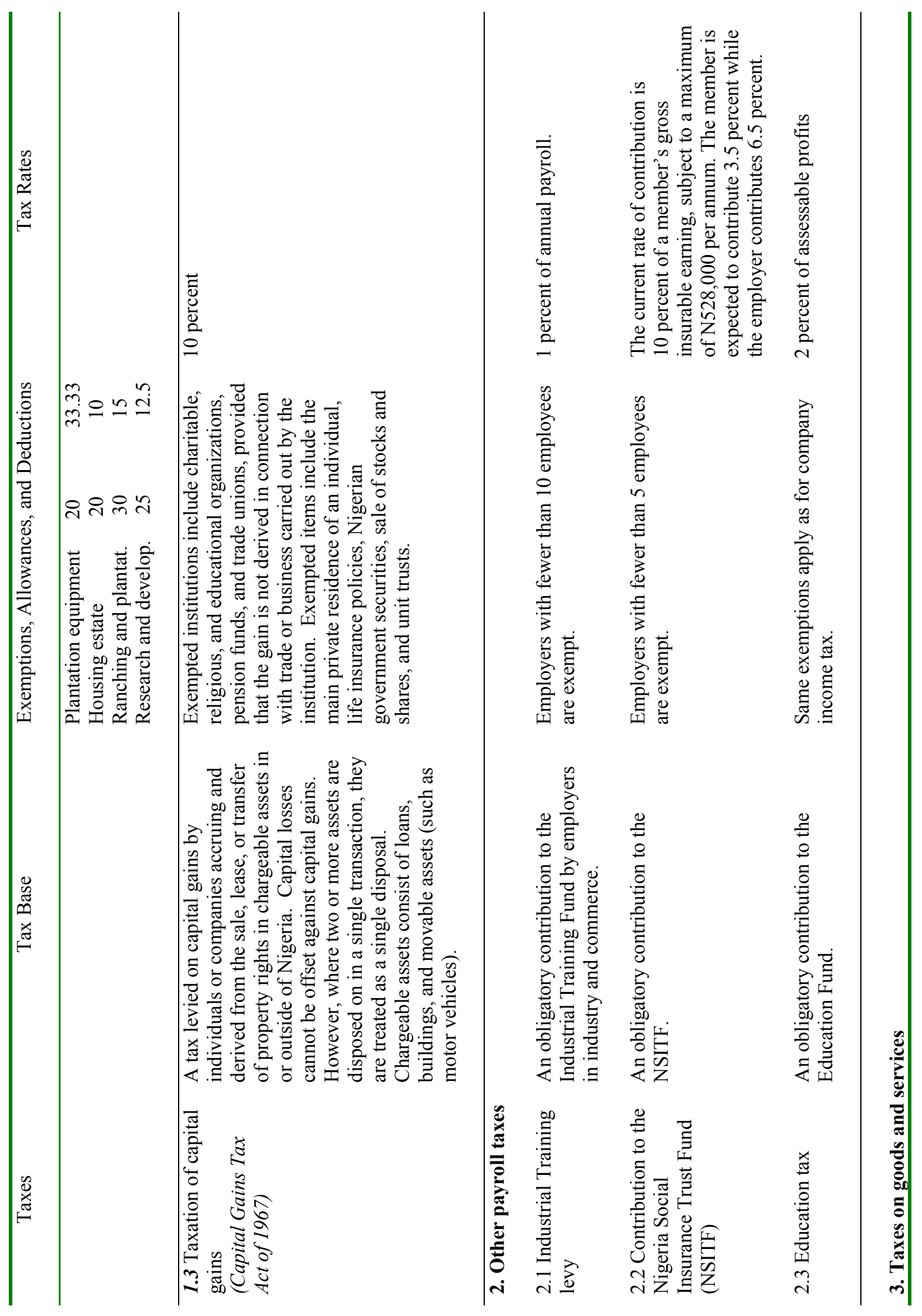









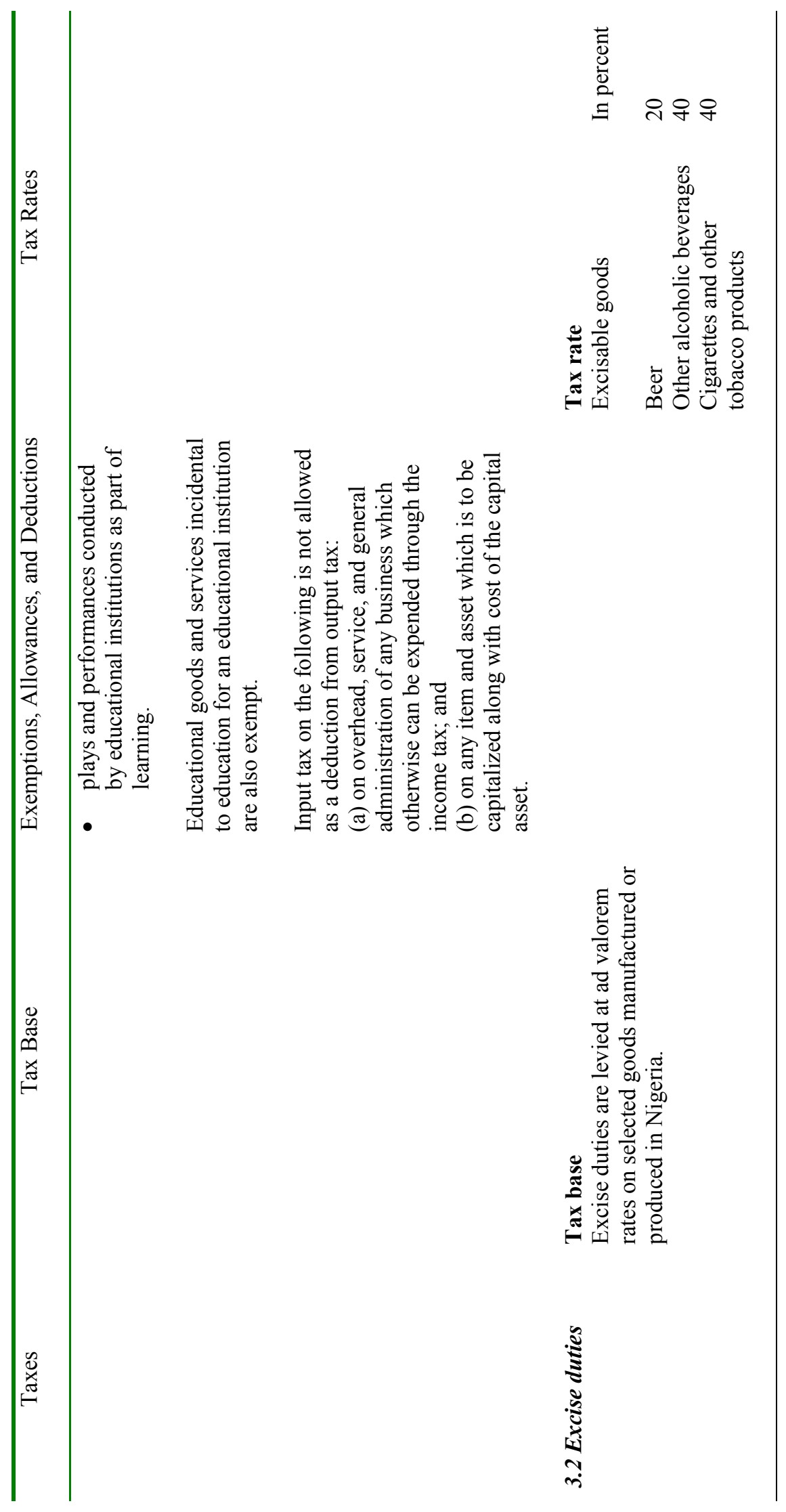




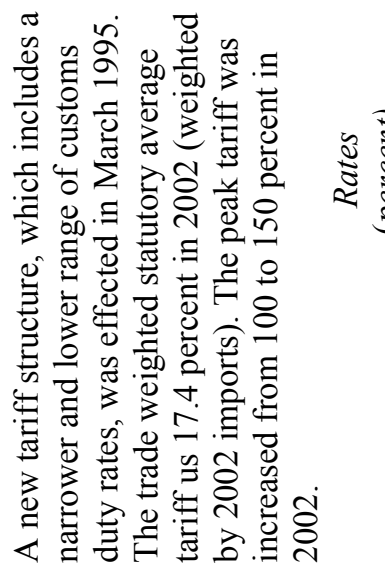

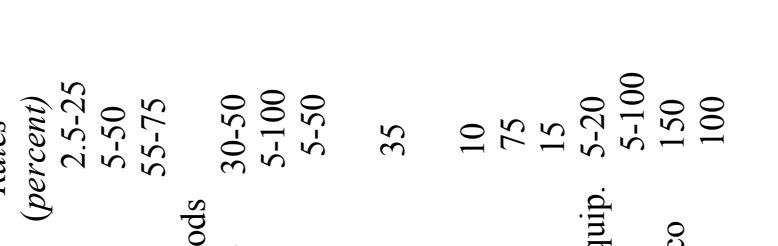

官芯

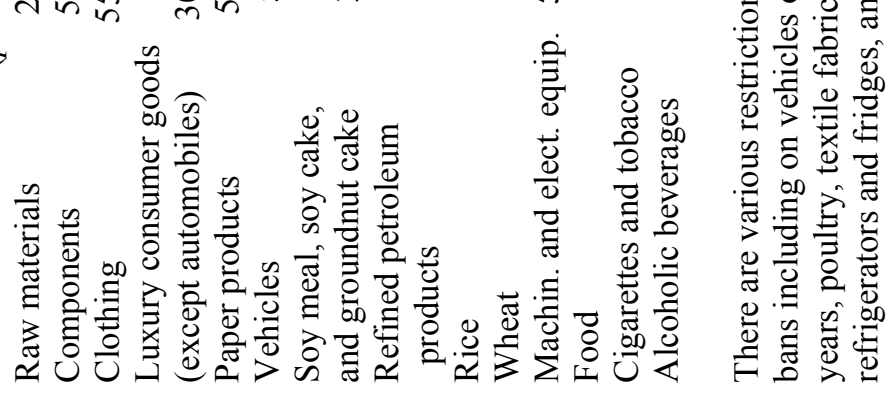

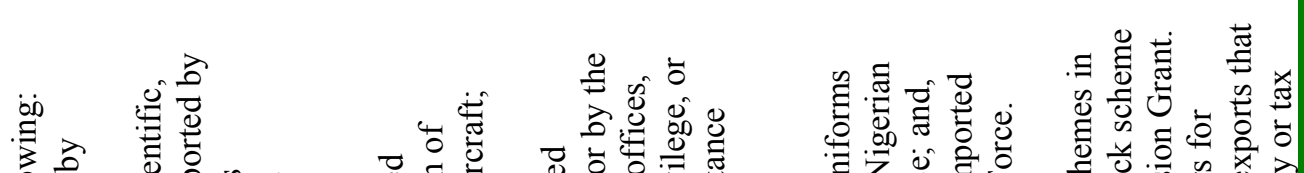

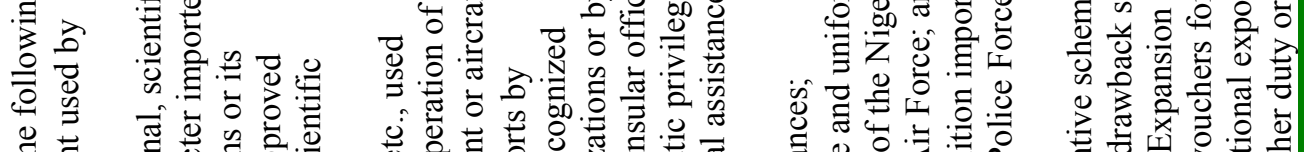

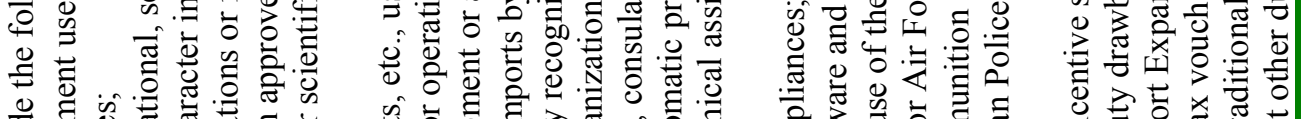

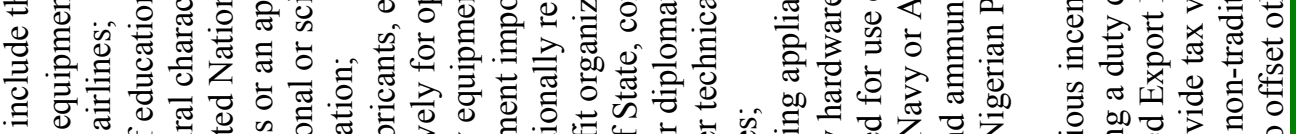

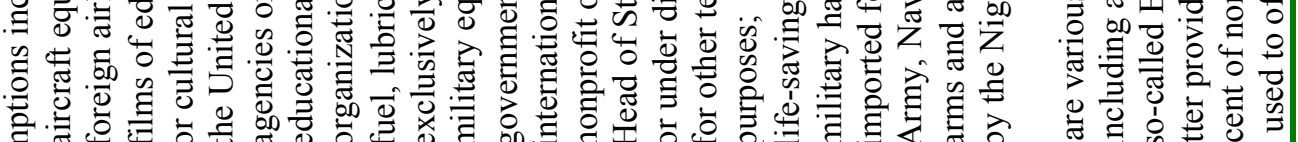

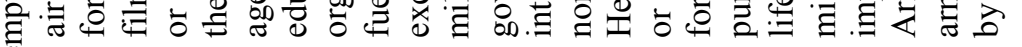
Ix

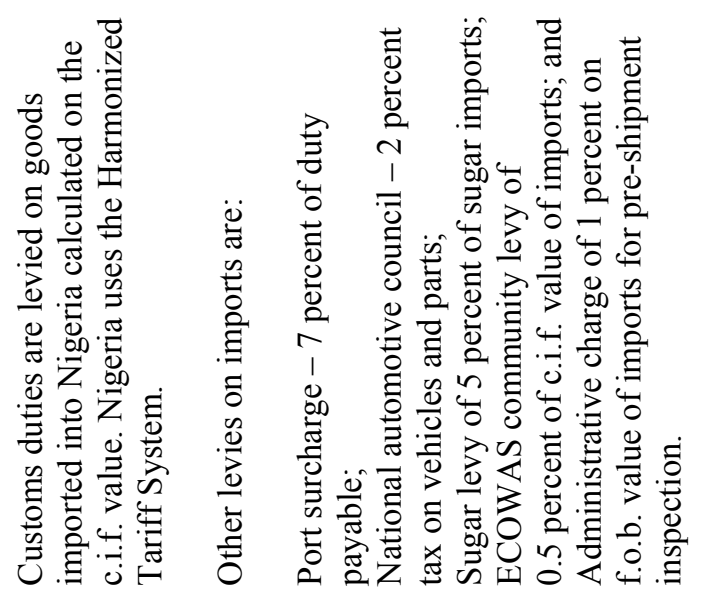

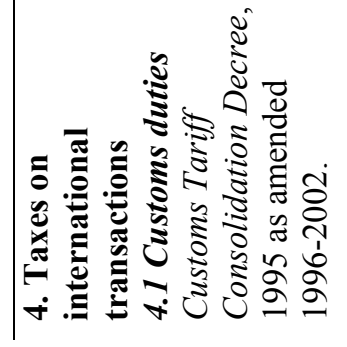




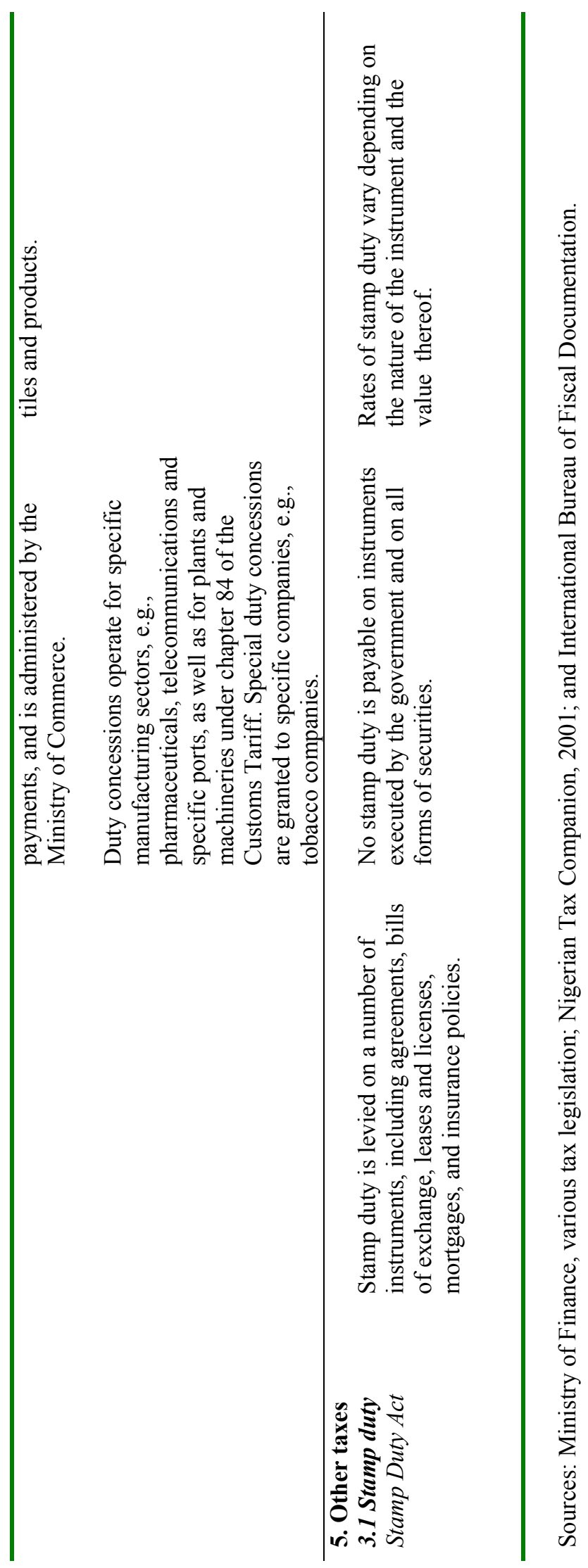

